\title{
Metodología y experiencia en la investigación etnohistórica: la evolución de las gonelles en Ibiza según la documentación escrita y gráfica (siglos XVIII-XIX)
}

\author{
RESUMEN
}

María LENA MateU PRATS

Basándose en fuentes escritas y gráficas de los siglos XVIII-XIX, además de en otros testimonios del XX incluidos como apéndice, se analiza la evolución que pudieron tener en Ibiza las gonelles tradicionales, en general consideradas pervivencias fósiles de épocas lejanas. Frente a ello, y por carecer el pueblo de memoria histórica, se señala la necesidad metodológica de estudiar esta manifestación indumentaria desde la perspectiva etnohistórica, conjugando el trabajo de documentación y de campo con el estudio iconográfico.

Palabras clave: Documentación, Etnohistoria, Ibiza, Indumentaria, Metodología.

\section{SUMMARY}

Drawing from written and graphic records of the $18^{\text {th }}$ through the $19^{\text {th }}$ century, as well as other sources included in an appendix, the author analyzes the possible evolution in Ibiza of the traditional gonelles, generally regarded as survivals from long gone times. Given this conventional wisdom, and the public's lack of historic memory, the author argues for the need to study this attire from an ethnohistorical perspective, combining fieldwork with research on written and graphic documents.

Key words: Documentation, Ethnohistory, Ibiza, Attire, Methodology.

\section{INTRODUCCIÓN}

Después de haber realizado algunos estudios sobre la indumentaria en Ibiza desde la perspectiva etnohistórica, he considerado conveniente referirme a la evolución que es posible detectar en los trajes femeninos de carácter tradicional a través de la documentación escrita y gráfica, como puente entre el pasado aún desconocido de esta manifestación y el pre-

RDTP, LVIII, 1 (2003): 85-152 
sente de la misma. Para ello, y de acuerdo con lo expuesto al respecto por Ortega y Gasset, parto de la consideración de que la gracia del traje popular "no está en su efectiva antigüedad, sino precisamente en la portentosa ilusión de vetusted, más aún de sin-edad, que el pueblo da a cuanto adopta, aunque sea de ayer" (Ortiz Echagüe 1971: 4).

Con ello tampoco niego la posible existencia de prendas o piezas arcaizantes que, tal como he venido repitiendo en otras ocasiones, pueden pasar así a convivir, incluso en un mismo modelo indumentario, con otras más novedosas. Nadie puede negar, por otro lado, el que ciertas formas sugieran las de otras épocas. Lo no científico es presentarlas con rotundidad como claras pervivencias, y, más aún, el ir negando sistemáticamente para ello, la validez de tódos cuantos documentos puedan levantarse como obstáculos para tal interpretación.

Este artículo no tiene por destinatarios a aquellos que mantienen esquemas simplistas sobre temas complejos, y se muestran cerrados a una renovación científica, sin atender a cuantos argumentos pueda venir a ofrecerles la investigación etno-histórica. Este estudio va dirigido a todos cuantos, de una manera abierta, estén dispuestos a escuchar, a sopesar y, lógicamente, también a discutir, los razonamientos a que me ha conducido el estudio documental e iconográfico de unas variantes indumentarias femeninas que pudieron gozar de una representativa implantación social en el ayer de Ibiza.

Para el siglo XVIII, me referiré, en primer lugar, y nuevamente, a la gonella que viene denominándose de clauer, y que, con la flocadura que la caracteriza, se halla representada en las pinturas de 1763 del púlpito de la Iglesia de Sant Josep de sa Talaia (Mateu Prats 1991, 1993 y 1996). Comentaré también, y por primera vez de forma específica, la "Labradora Yvizenca", que, en 1777, grabó D. Juan de la Cruz Cano y Olmedilla (1771), sobre dibujo de Antonio Carnicero, y que, principalmente por el mucho menor conocimiento que se tiene de ella, puede causar una mayor sorpresa y consecuente mayor resistencia en su aceptación como propia de nuestro pasado.

Para el siglo XIX, y tras partir de la versión que A. Rodríguez y A. Albuerne hicieran en 1801 del grabado de Juan de la Cruz (1801)1, haré asimismo alguna alusión a los grabados que igualmente se han dado a conocer este año en la isla, gracias a la exposición organizada por el Arxiu Historic d'Eivissa, y cuya realización y catálogo han corrido a cargo de

\footnotetext{
${ }^{1}$ Estaba igualmente en mi intención analizar la acuarela realizada sobre la indumentaria femenina llevada en Ibiza por G. Chiesa. Acuarela de la que se tiene noticia por A. Mulet (ibid. 1951: 14) y que, por el momento, aún no he podido localizar.
} 
Anna Colomar (Arxiu Historic d'Eivissa 2002), si bien dejo para otra ocasión el estudio más detallado de los mismos. Estoy hablando de "A woman of Ivissa" publicada por Giscard en 1822 ( ibid.), de la "Payssanne des environs d'Yvice" de Edme Jean Pigal (ibid. 1825), y de la "Labradora de la Ysla de Yviza", recogida en la Colección de Trajes de España de José Ribelles y Helip (ibid. 1832). Grabados, todos ellos, que, salvo algunos detalles, prácticamente también responden al modelo de Juan de la Cruz. El punto final a este recorrido sobre la indumentaria portada tradicionalmente en Ibiza según las ilustraciones de la época, lo pondrán las ya ampliamente divulgadas del Archiduque Luis Salvador (ibid. 1869-1891) y G. Vuillier (ibid. 1893). Dejando ahora aparte aquellas fotografías y acuarelas de principios del siglo $\mathrm{XX}$ que constituyen un apéndice cronológico para el traje de clauer.

Parto también de la base de que, por más que la mayor parte de estas obras no se adapte a la idea que hoy tenemos de la indumentaria tradicional conservada, no conozco justificación alguna suficiente que autorice a apartarlas de nuestra perspectiva, a la hora de intentar adentrarnos en los antiguos usos indumentarios de la isla.

"El pueblo - ha escrito, por citar otro ejemplo, Antonio Beltrán (1991: 27-32) - no tiene memoria histórica, hace las cosas intemporales, y para él lo más antiguo es lo correspondiente en la generación que ha conocido", por lo que "el tope máximo parecerá eterno y de siempre". "Al convertirse el traje en seña de identidad" — sigue diciendo- se puede llegar a simplificar la enorme variedad en un solo traje típico, o a convertir "innovaciones temporales en rasgos definitivos y el conjunto en un símbolo". "En síntesis - termina afirmando- el traje típico popular establecido entre los siglos XVIII y XIX tiene poco que ver con el auténtico [...]. Será falso rotundamente hablar del traje aragonés, del catalán, del valenciano o andaluz... [...]. La generalización o la simplificación tópica, por desgracia es la constante que predomina en los escritos o exposiciones sobre el traje popular", especialmente "cuando ha dejado de usarse a diario y se ha convertido en "objeto de museo".

I. CONSIDERACIONES PREVIAS SOBRE LA INDUMENTARIA Y JOYERÍA DE CARÁCTER TRADICIONAL

\section{Observaciones en torno a las posibles pervivencias y paralelismos}

Dadas las características de este estudio, me he permitido enfocar el presente apartado de una manera personal, exponiendo los caminos de 
investigación que se me han ido abriendo con el paso de los años, a modo de consideraciones previas sobre la indumentaria y joyería de carácter tradicional. Pienso que el dar a conocer mi propia experiencia en este campo es la forma más directa y sencilla de explicar los motivos que finalmente me han llevado a reconocer los Protocolos notariales y la iconografía como fuentes específicas de estudio para estas dos manifestaciones de carácter popular.

Antes de emprender la vía de investigación etnohistórica que hoy vengo desarrollando, y allá por el año de 1983, en la Memoria de Licenciatura ${ }^{2}$ con que accedí al correspondiente Grado en Prehistoria y Arqueología, me hacía eco de la raigambre medieval que algún que otro autor había observado para el traje de la gonella negra conservada en Ibiza. "Dejando aparte las consideraciones de la posible antiquísima raigambre" para dicho traje -escribíamos en la publicación oportuna (Mateu Prats 1984: 144)_: "es necesario constatar la opinión de quienes, por el contrario, mantienen que el citado traje ibicenco como el de Ansó son propios de la Edad Media, constituyendo asimismo islas independientes en el cuadro general de los atavíos españoles".

Tras ello, y admitiendo tal ascendencia para muchos de sus elementos (ibid.), proseguía aportando todos aquellos datos que había podido recoger sobre algunas de las prendas que lo configuran; en unos casos, mediante la localización de ciertas alusiones hechas ex profeso para la indumentaria de nuestras islas, y en otros valiéndome de las apreciaciones formuladas para otras parecidas o de la misma tipología. Los años en los que se realizaron algunas de esas reseñas repercutían favorablemente en el conocimiento de algunas peculiaridades o características que pudieran haberse incluso olvidado, y en lo concerniente a la propia condición científica de esas fuentes, aún hoy siguen considerándose material básico de consulta.

En todo caso, la principal aportación que, con ese acopio de datos y por aquel entonces, creí realizar, fue la de dar a conocer o de difundir en la isla no sólo aquellas reseñas que sobre la indumentaria popular de Ibiza y Formentera pudieran circular en la península, sino las apreciaciones que, ya desde hacía años, se habían formulado al menos para algunas de las prendas que, en cada sitio en particular, podían seguir viéndose de ámbito exclusivamente local. Sirva aquí de ejemplo la mantellina configurada por un semicírculo de paño, tan representativa en nuestro vestir antiguo, y que Nieves de Hoyos constataba como "la mantilla más gene-

\footnotetext{
2 Bajo la dirección del Dr. D. Gratiniato Nieto Gallo, Catedrático de Arqueología en la Facultad de Filosofía y Letras, Universidad Autónoma de Madrid.
} 
ral en el vestir de España", aunque realizada con diferentes tejidos, según unas u otras zonas (Hoyos Sancho 1935: 186) . $^{3}$.

Las fuentes orales y bibliográficas utilizadas me permitían, asimismo entonces, proseguir diciendo que "Ibiza con el traje de 'gonella' negra rompe con una de las características fundamentales de la zona mediterránea, en la que predominan los tejidos flexibles y ligeros, tales como sedas, rasos y tules", esto es, con "la de su luminosa indumentaria". Ya que, "por el contrario, la opaca y severa textura de la estameña, los genuinos bordados que decoran el rectángulo superior del delantal y [...], el amplio sombrero de fieltro, le dan un carácter verdaderamente distintivo".

"La estameña - continuaba al respecto y rozando el tema que ahora ha vuelto a salir a colación - fue un tejido muy popular en la Edad Media, aunque es posible que 'estamenna' desapareciera entre los siglos XIII y XIV al menos del vocabulario castellano medieval, puesto que en esos momentos se conocía el tejido con el nombre de 'burel', 'sayal' y 'gerga'; tejidos en aquella época burdos de lana utilizados para los mismos fines, esto es, hábitos religiosos y lutos", si bien en épocas precedentes habían existido estameñas de mejor calidad (Alfau de Solalinde 1969: 100-101).

Todas estas apreciaciones se inscriben en lo que fuera mi propia Memoria de Licenciatura, cuando, fundamentalmente, tan sólo me valía de dos de las cuatro vías de investigación que utilizo actualmente, tal como detallo más adelante, en el oportuno apartado. Es decir, cuando básicamente me servía de la consulta bibliográfica y del trabajo de campo, éste en su doble vertiente de localización de piezas-testigo y recogida de información oral.

Sin embargo, antes incluso de proponerme realizar la Tesis Doctoral sobre los trajes y joyas de Ibiza desde una perspectiva etnohistórica, fue necesario adoptar una metodología más completa, en la que el estudio de las fuentes iconográficas y archivísticas ocupase un papel primordial. Con este enfoque presenté el correspondiente proyecto de tesis en la Universidad Autónoma de Madrid, siendo aceptado por la comisión competente y matriculada en $1987^{4}$ (aunque el participar en un proyecto de investigación motivara que, finalmente, dedicara la tesis a otra zona de nuestro país ${ }^{5}$.

\footnotetext{
${ }^{3}$ Cito por Mateu Prats (1984: 145).

${ }^{4}$ La indumentaria y joyería en Ibiza (siglos XVI al XX), bajo la dirección del Dr. Cea Gutiérrez, Investigador del CSIC (Madrid).

5 Mateu Prats, M. L. 1994 La sociedad sayaguesa a través del mundo de los oficios; I-V, igualmente bajo la dirección del Dr. Cea. Madrid: Universidad Autónoma de Madrid.
} 
En esta segunda etapa de mi propia trayectoria profesional, no sólo se ha ampliado cronológicamente el campo de estudio en función de la metodología empleada, sino la misma forma de presentar los datos. Así, y por ejemplo, al acusado respeto por la palabra escrita de la primera etapa, que podía hacer admitir como verdades probadas ciertas apreciaciones, ha seguido ahora una especial prudencia. De esta forma, si cuando estaba dando el paso de alumna a licenciada mis conocimientos no me permitían cuestionar las opiniones hasta entonces manifestadas, quizás hoy las investigaciones que vengo realizando me obliguen a ello.

Aplicando esta obligación científica al caso que nos ocupa, y ante la señalada consideración de la gonella negra como pervivencia medieval, tendría que hablar de ciertos rasgos susceptibles de poder interpretarse como tales. Uno de ellos, el grueso tejido que ha venido configurándola; otro, la repetida hechura de cuerpo corto y largo faldar. Siempre y cuando otros documentos, insisto, no vengan a obstaculizar tal interpretación.

Antes de referirme a ellos, juzgo conveniente dedicar, al menos por un momento, la atención al traje ceremonial de las mujeres de la localidad aragonesa de Ansó (figura 1); basquiña que, como indicaba, ha sido comparada con la gonella negra de Ibiza, y de la que parece partir la consideración medieval para ambas, en función de su similar hechura (Ministerio de Cultura 1991: 116, 185, 187). También como la gonella de Ibiza se complementa con unas estrechas mangas incorporadas que, en este caso, vienen a subrayar el abullonamiento de las mangas de la camisa a la altura de los hombros, de forma similar a como veremos se muestra en alguna ilustración sobre la indumentaria en Ibiza durante el siglo XVIII.

Sin embargo, en lugar de lucir sombrero sobre cambuix, o pañuelo atado bajo la barbilla, éste - tal como podemos apreciar en la lámina aquí reproducida - se dispone en torno y sobre la cabeza, de forma que, en cierto modo, evoca el tocado de rollo a la morisca, al que aludíamos en otro estudio (Mateu Prats 2003: 96-97), al plantear la posibilidad de que el mismo hubiera podido llevarse otrora en Ibiza como consecuencia de esta corriente ornamental. Si bien, para ser fieles a la descripción ofrecida sobre el tocado y peinado de las ansotanas, éstas "formaban con el pelo dos trenzas, a las que añadían un postizo llamado churro, recubrían las trenzas con hiladillo ancho y las colocaban en forma de corona, cubriendo el peinado con el tocado o redecilla" (Hoyos Sancho 1935: 175-186) ${ }^{6}$. Por más que según otros autores, como Ortiz Echagüe, dicho tocado no consistiera sino en encintarse las trenzas y disponerlas en rodete o aureola a la cabe-

\footnotetext{
${ }^{6}$ Cito por Casado Lobato (1991: 14).
} 
za, en lugar de dejarlas caer sobre la espalda, como en Ibiza se hacía con el traje de clauer (Ortiz Echagüe 1971: 20).

De la ansotana llama también especialmente la atención el cuello alto en abanico, o valona, en este caso alechugada. Con ello vemos cómo al analizar el propio traje de fiesta de Ansó, tantas veces puesto de ejemplo como pervivencia de la etapa medieval, se desvela la incidencia de modas de otros momentos históricos posteriores, por más que la mencionada valona pueda a su vez seguir considerándose un rasgo arcaizante dentro del panorama de la indumentaria tradicional de nuestro país.

De modo similar a como ocurriría con estos cuellos en Ansó, parece que también iría quedando fosilizado uno de los modelos indumentarios que se viene mostrando como ejemplo de antiguas pervivencias: el traje de boda de la Sierra de Francia (Salamanca), llamado en la Alberca de vistas, dádivas o davias en Mogarraz, de

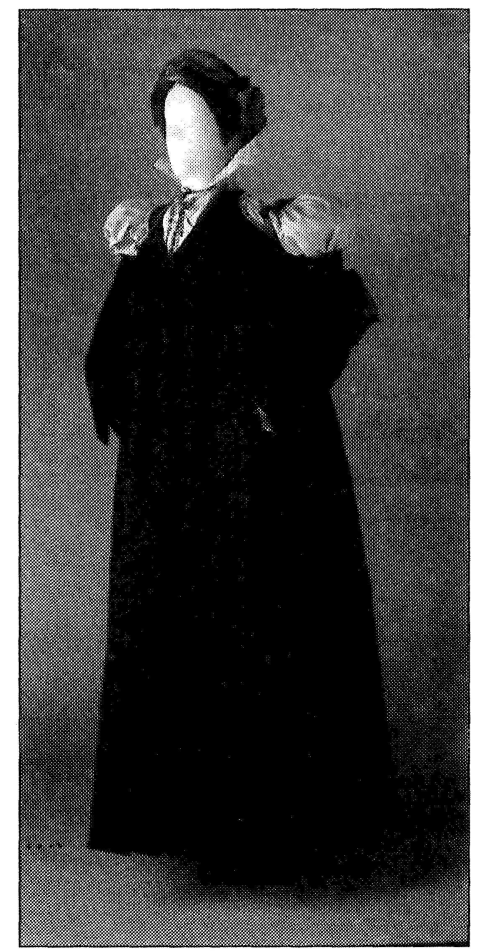

FIgURA 1.-Traje de fiesta de Ansó?. sayuelo en Valero y de arras en Candelario (Cea Gutiérrez 1986: 121). Traje del que puede decirse que, en conjunto, corresponde al siglo XVII, que, pese al anterior ejemplo, viene considerándose como "el más hierático y ancestral de todos los trajes españoles" (Ministerio de Cultura 1991: 130) (Figura 2), y del que ya habló aquí en Ibiza, al inaugurar las II Jornadas de Cultura Popular, precisamente, quien viene siendo su investigador por antonomasia.

Me refiero a Antonio Cea, investigador del CSIC, en Madrid, y con quien contacté por primera vez cuando realizaba la aludida Memoria de Licenciatura, al objeto de corroborar los paralelismos que parecían existir entre los trajes de Ibiza y esa otra región, fundamentalmente en función de las joyas con que ambos se complementan. Pude así comprobar la similitud tipológica existente entre los rosarios de plata y coral utilizados aquí y allí sobre el pecho, al tiempo que, consecuentemente, también admitía para los de uso en Ibiza, la pervivencia de diseño del siglo XVII reconocida para aquellos otros (Mateu Prats 1984: 158).

\footnotetext{
7 Ilustración de Moda en Sombras (Ministerio de Cúltura 1991: 117).
} 


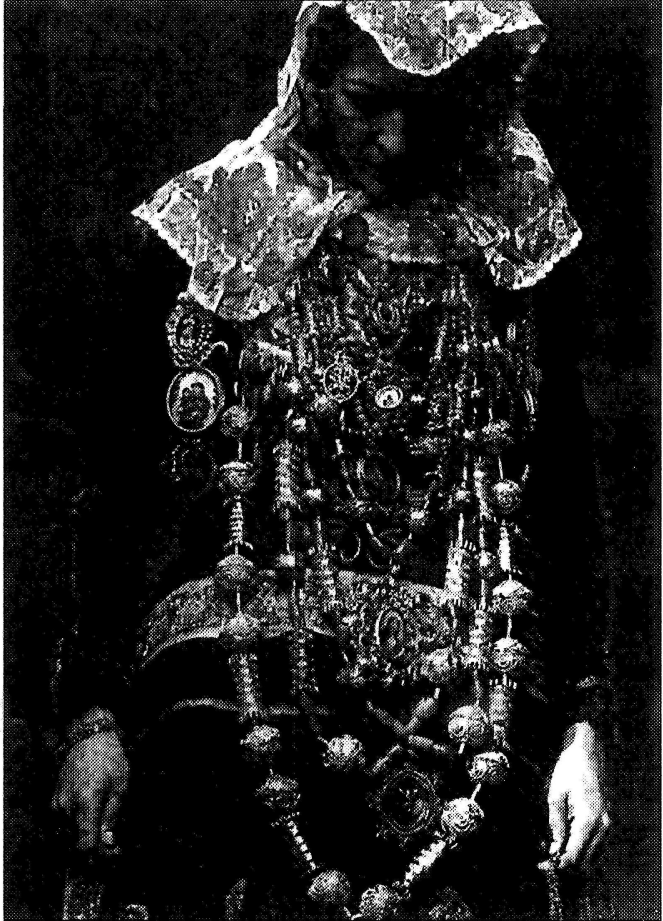

Figura 2.-Traje de vistas de la Alberca ${ }^{8}$.

Con ello, asimismo pude observar cómo las vistas de esa región semejan ser la ostentación conjunta de las dos emprendades que aquí conforman hoy conjuntos ornamentales independientes, según sea la plata y el coral o el oro los materiales que los configuran. Aunque a mediados del siglo XIX, A. Flores, el cronista oficial que acompañó a Isabel II en su viaje a las Islas Baleares, alegaba que las ibicencas, con gonella negra, complementaban su atuendo con un conjunto de joyas de oro y coral, lo que ha inducido a pensar que trataría de una emprendada de transición entre la de plata y coral y la de oro (Fajarnés 1995: 145).

"En las 'vistas' de la Alberca -escribía en el estudio comparativo-, el 'collaret' tiene su equivalente en el 'gran collar' [...], que, al igual que en Ibiza, enmarca todo el conjunto, y del que pende un gran relicario, con el mismo efecto de 'sa Joia' ibicenca, tanto por su calidad de 'relicario de vidriera' como por su semejante ubicación. El 'cordoncillo' y, sobre todo, la 'agustinada' de coral, tienen su equivalente en los 'granos de coral' de aquellas. La 'Creu', y (como indicaba), la 'Joia', en las múltiples cruces, crucifijos y, sobre todo, 'relicarios de vidrieras' (aunque nunca distribuidos en tres cuerpos). El 'aguila bicéfa" en elementos similares y el regalo tradicional de los anillos ibicencos con corazones como colgantes, en el 'corazón de la novia' de aquella región, que se sitúa en el lugar que en la 'emprendada' ibicenca ocupa 's'adrec'" (Mateu Prats 1984).

Independientemente de las precisiones y ampliaciones que haya podido ir realizando sobre este mismo tema, ahora interesa volver a recordar que, tanto las cuentas bitroncocónicas del collaret ibicenco, como las bollagras y arconciles del gran collar salmantino encuentran paralelismos

\footnotetext{
${ }^{8}$ Ilustración de A. Cea (1985: 57).
} 
diacrónicos en el collar hispano-morisco de Mondújar (Mateu Prats 1985). Lo que a su vez me lleva a insistir en la fosilización de tocas de esta misma raigambre en la indumentaria salmantina (Cea Gutiérrez 1986: 145), y al posible uso de análogas en otro tiempo en Ibiza, tal como sugería en el artículo sobre las Robes a la morisca... (Mateu Prats 2003: 91).

Para algunos autores, como A. Beltrán, el cierto grado de pureza, "a despecho de degeneraciones falsas", que pueden presentar, por ejemplo, los trajes ceremoniales de Ansó y de la Sierra de Francia que venimos comentando, se explica por su propio carácter festivo y por razones fundamentalmente económicas. Siguiendo sus propias palabras, "se usaban en muy pocas ocasiones, se conservaban a través de generaciones" y, por las aludidas razones económicas, casi inmutables, "acababan convirtiéndose en definitorios de comarcas o de pueblos por un curioso fenómeno de persistencia a la que pudo contribuir también el elemento cultural de falta de estímulos para el cambio y de apreciación de la 'novedad' como algo peligroso que debía ser evitado" (Beltrán 1991: 27).

Teniendo igualmente en cuenta la circunstancia de que cada zona queda "parcialmente determinada por los productos naturales en relación con las materias primas, complementados por las importaciones y las vías de comunicación", resulta singularmente expresivo - de acuerdo con el mismo autor- comprobar cómo el citado traje de Ansó, así como el del Roncal o Hecho, que entrado el siglo XVIII se extendía a todo el campo de Jaca, con diferencias locales de detalle, tan sólo se haya conservado en los valles cerrados y mal comunicados, y se haya perdido, en cambio, en las zonas más abiertas (ibid.: 29-30).

Según otras opiniones, sin embargo, "toda la carga ornamental, de poder, y hasta de signos que es capaz de acumular el hombre en el vestido", se da en alguno de los referidos ejemplos "en un grado tan elevado, que induce a pensar en una razón más poderosa que la simple inercia en la moda o en la de la fijación de unas formas fosilizadas por aislamiento" (Cea Gutiérrez 1986: 119). Siguiendo esta postura, "los motivos que tenga una comunidad para fijar, contra corriente, unas prendas como suyas, logrando que se la reconozca, en parte, por ellas, no puede deberse sólo a unos intereses tan movedizos y pasajeros como los de una determinada forma de vestir" (ibid. $)^{9}$

Esta idea de "una intencionalidad diferenciante en el traje", que A. Cea ha creído observar en la indumentaria tradicional de la Sierra de Francia,

${ }^{9}$ Este mismo autor, en otro estudio señala cómo "el clero, los hombres de leyes y de Universidad, los militares y algunos profesionales llanos, como los arrieros en el caso de los maragatos o más tarde los toreros, mantuvieron prendas arcaizantes para emblematizar su estatus, jerarquía, privilegios o buen hacer" (Cea Gutiérrez 1991a: 10-14). 
podríamos aplicarla quizás a la propia Ibiza, teniendo en cuenta el parecido que este mismo investigador ha reconocido entre esa zona y nuestra isla, fundamentalmente en lo que concierne a la joyería, donde "perseveran materiales y símbolos que desaparecieron en el siglo XVIII en otras zonas del país". Aunque, tal como igualmente matiza, no se trate de "un parentesco a simple vista", sino tan solo perceptible para aquel "que estudia el traje a fondo y ve los hilos conductores que mueven a las dos sociedades" (Cea Gutiérrez 2002a: 13).

\section{Otras consideraciones antropológicas sobre el traje}

Junto a todos estos razonamientos esgrimidos a la hora de explicar posibles pervivencias morfológicas y/o simbólicas en la indumentaria y joyería tradicional, también se ha destacado que el vestido responde a una serie de factores naturales y a estímulos intelectuales, tales como la propia protección contra las inclemencias del tiempo, aunque a veces puedan intervenir situaciones intelectuales que nada tienen que ver con ellas, como el uso de pesadas capas en pleno verano o de faldas femeninas en Murcia en contradicción con el caluroso ambiente, del tipo de las castellanas, y que se vienen explicando como resultado de la conquista del reino durante la Edad Media (Beltrán 1991: 28).

Todo lo cual nos conduce, dentro de los límites isleños que aquí nos interesan, a recordar el uso por los ibicencos de los lúgubres caputxos, aún en el más caluroso estío — con lo que a su vez se desvela la incidencia de los factores rituales en el traje (ibid.)-, así como la propia textura que ha venido caracterizando a la gonella negra y, por la que, como veíamos, se ha señalado que rompía con una de las características de la zona mediterránea, de "luminosa indumentaria", donde predominan los tejidos flexibles y ligeros.

Era y es en función de la calidad de los tejidos y materiales como se establecen las verdaderas e insalvables diferencias sociales del traje, tanto o más que las hechuras. Pues ésta, tal como igualmente se ha señalado, sobre todo delataba la mentalidad tradicional o por el contrario vanguardista del que vestía al "estilo de la tierra" o "a uso de los ciudadanos", respectivamente (Cea Gutiérrez 1991a). Esto es, manteniéndose por más tiempo anclados en patrones tradicionales, o siguiendo de forma más o menos sincrónica los constantes cambios o vaivenes de la moda en el vestir ${ }^{10}$. Lo

${ }^{10}$ En el primer aspecto -y conjugando lo expuesto por los dos autores a que aquí venimos haciendo especial referencia-, si es cierta la norma por la que cada 
que no implica un diferencia radical entre ambas formas, ya que en la imitación de lo señorial, aunque de forma ralentizada y empobrecida, parece encontrarse el propio origen de los trajes tradicionales ${ }^{11}$.

La incidencia de las modas en principio aristocráticas en los estratos populares, ya ha quedado claramente manifiesta aquí con la fosilización de las valonas alechugadas en el traje de Ansó. Valona que se ha identificado en alguna ocasión con las lechuguillas, si bien, dicha denominación se corresponde, de manera específica con la gorguera que muestra la "Labradora Ybyzenca" de Juan de la Cruz, atendiendo a la oportuna especificación de A. Cea. Si las primeras noticias que se tienen de este adorno están en relación con las ropas de la emperatriz a principios del siglo XVI (1529-1538) $)^{12}$, su trascendencia en la moda durante la segunda mitad de dicha centuria y principios del XVII ${ }^{13}$, queda claramente constatada con el uso que de ellas ya hacían incluso las labradoras en esta última centuria (Puiggarí 1979: 210).

cual debía vestir como "era debido", según la condición social a la que pertenecía, también lo es la imitación por los estratos populares de lo señorial, salvo en los elementos que pudieran ser exclusivos de ciertas clases. "Una imitación por la que incluso se ha podido llegar a jugar a derribar barreras sociales, en determinados y cortos momentos, tal como ocurrió con los trajes de chisperos, majos y otras excentricidades dieciochescas. Aunque, por lo usual, dicha imitación popular se haya venido produciendo según los principios generales de simplificación que con la intemporalidad y el anonimato tiñen todas las adaptaciones del pueblo, añadida a la tradición y el conservadurismo" en la forma que iremos matizando, fuertemente condicionada por el menor poder adquisitivo.

${ }^{11}$ De ellos, España presenta el acervo de mayor riqueza y variedad, consecuencia de las múltiples diferencias geográficas, económicas, políticas y religiosas, étnicas y, en suma, culturales. A la pregunta de ¿cómo se originaron trajes tan diversos en nuestro país? tendríamos que contestar que esta riqueza nació al morir, siguiendo las propias palabras de quien así lo ha observado: "Cada época originó sus modas, cada moda fue, en principio, privilegio de la élite que las iba desechando para vestir otras más novedosas. La clase media las heredaba y la llana las imitó y fosilizó. La moda que se creaba en las ciudades llegaba a las aldeas más remotas en un tiempo breve - unos diez años- Los desiguales ritmos de la economía y la evolución fueron paralizando, a lo largo del siglo XVIII, los distintos relojes de las prendas, adornos, formas, colores y denominaciones, fenómeno que cristalizó definitivamente con la uniformadora moda a la europea, que en España viene a coincidir con la guerra de Independencia. Por ello y aunque se piense que los trajes, identificativos hoy de algunos pueblos existieron siempre y por supuesto nacieron allí, conviene más bien decir que tal pieza se conserva en más que es originaria de, lo cual no es pequeño honor" (Cea Gutiérrez 1991a).

12 Libro de cuentas de la recámara de la emperatriz [...] desde 1529 1538. Archivo de Simancas, Contaduría Mayor, $1^{\underline{a}}$ época, leg. 464. Cito por C. Bernis (1962).

${ }^{13}$ Véase "Lechuguilla" en (ibid:: 94) 
Hago especial hincapié en este trasvase de las modas en principio aristocráticas al pueblo, no sólo por la necesidad de demostrar su importancia en la propia comprensión de la indumentaria tradicional, sino también por la obligación científica de rectificar a quien puede haber desviado el tema por caminos erróneos.

"El supuesto 'respeto por la tradición' de las clases populares -afirma nuevamente A. Beltrán- es un tópico, como lo es el de la frugalidad, producido por pobreza y necesidad de conservar, mucho más que expresión de virtud congénita" (Beltrán 1991: 28). De esta forma, los trajes populares no suelen responder a patrones anclados en tiempos lejanos, sino que intentan seguir aquellos otros en boga entre las clases sociales más favorecidas, aunque la adaptación de esas modas se realice ya de forma anacrónica y adaptándose a los tejidos más burdos o humildes del mundo rural. La diferenciación sincrónica entre ambos mundos que esta circunstancia conlleva, en realidad no hace sino ocultar la similitud diacrónica existente entre ambos.

Por todo ello, cuando se procuran establecer las bases económicas del traje, así como cuando se intenta analizar la uniformidad de atuendos según determinadas profesiones y actividades, ocasiones y épocas (pastores, campesinos, menestrales), resulta fundamental apoyarse en consideraciones sobre la distinta incidencia de lo rústico y lo urbano, y reconocer la servidumbre del mundo rural hacia las sucesivas tendencias indumentarias de los burgueses, clases adineradas y aristocráticas.

El hecho de que la evolución de la moda responda a la de la propia cultura hace que dicha evolución responda a la de las ideas éticas o morales, además de a la del propio concepto de belleza; ideas todas cambiantes según las épocas. De ello deriva la intencionalidad de excitación o contención sexual mediante la ostentación u ocultación de determinadas partes del cuerpo. Si es que a éstos factores ya no responden a la condición más o menos llamativa, o, por el contrario severa, de los correspondientes modelos indumentarios.

Por este motivo, la configuración de los trajes no puede observarse bajo un punto de vista meramente tipológico o superficial. Y no podemos pasar por alto, citando ahora otro ejemplo que especialmente nos interesa, cómo las mujeres de diferentes estratos sociales pudieron compartir el interés, en unas u otras épocas, por resaltar la estrechez de sus talles con apretados corpiños, o cómo también en ciertos momentos los mozos se valieron de prietas calzas para destacar sus "buenas piernas", valiéndonos de la expresión usada por las mujeres de alguna que otra localidad (Beltrán 1991: 28).

Junto a este tipo de consideraciones, que demuestran el valor del vestido como arma principalísima a favor de los diferentes cánones esta- 
blecidos, en un momento u otro, sobre la belleza, y encaminadas principalmente a potenciar la atracción física (cuando los trajes no adquieren connotaciones honestas o ceremoniales), están aquellas otras de carácter simbólico por la que la indumentaria sirvió de código, y cuya lectura y comprensión - hoy en parte indescifrable - nos sobrecogería, tal como se ha señalado. "Dentro de este apartado se inscriben los ceñidores, que dividiendo el cuerpo en dos mitades, vendrían a significar el esfuerzo y la profesionalidad en el hombre, mientras que los de la mujer colgaban rosarios, tijeras, llaves y otros dijes que, por lo regular, hablaban del hogar y de la hacendosidad (Cea Gutiérrez 1991a: 22-26 y 1991b), además de la formación cristiana".

Confieso que una de las mayores satisfacciones que me ha podido producir la investigación de la indumentaria y joyería, y más concretamente la del clauer, fue el corroborar estas últimas apreciaciones en una obra del siglo XVI tan significativa al respecto como es La perfecta casa$d a$, de Fray Luis de León, dejando ahora aparte las consideraciones feministas que hoy podamos hacer sobre el tema. ¿Para qué fin -se preguntaba- "ordenó Dios a la mujer, y se la dio por compañía al marido", sino "para que lo que él ganase en los oficios y contrataciones, de fuera, traído a casa, lo tuviese en guarda la mujer y fuese como su llave?". Así las "buenas mujeres" debían ser "guardas de su casa", "pues las hizo Dios para ella sola", debiéndose contentar con "su suerte", "de sus puertas adentro".

Pocos textos pueden resultar tan significativos como éste sobre el valor simbólico y correspondiente contexto social de este conjunto de llaves y otros posibles adornos que, pasado el tiempo, se constatarán también en el elemento ornamental dieciochesco por excelencia. Aunque el consultar obras literarias en la investigación etnohistórica y el detenerse en este tipo de consideraciones, tal como se viene haciendo, por ejemplo, en el Consejo Superior de Investigaciones Científicas, haya podido ser, lamentablemente, recriminado, por quien ignora el valor de esta fuente de estudio y el contenido simbólico que a veces encierra dicha manifestación.

Precisamente, en un estudio reciente sobre "La indumentaria en el refranero de Correas. Retrato y caricatura de la España del siglo XVII", A. Cea (2002b) ha vuelto a referirse de manera concreta a este aspecto, señalando que la imagen de la belleza en la casada debía de emparejar con la de la mujer hacendosa, ancestralmente representada con el huso y la rueca (en la iconografía y en la literatura). "Es la visión de la mujer de su casa, honesta, buena administradora y fuente de riqueza, hilando lino y lana y con las llaves colgando del ceñidor: La mueca en la cinta y los pies en la bailía; Digo una y digo otra, que quien no bila no trae toca, 
según las manos de quien anda (Se conservan 89 refranes sobre el estereotipo de la buena y la mala hilandera, que es tanto como decir la buena o la mala esposa y ama de casa)" (Cea Gutiérrez 2002b: 105).

"La cinta, cinto o ceñidor de mujer -insiste más adelante, aludiendo al tipo de joya íntimamente asociado al clauer (ibid:: 127-128) - aparece en los refranes como descansadero de la rueca, emblema e icono de la perfecta casada y de la mujer hacendosa. Así se emplea: La rueca en la cinta y los pies en la bailía. Cuando se dice: No toméis cinta de plata, probablemente se está aludiendo a la mujer que pique alto con un matrimonio de buena posición; que no vale la pena hilar si no es con cinta y rueca de plata". "La cinta se toma también en la mujer - prosiguecomo la prenda de la que cuelgan las llaves de la casa y la hacienda y por ello puede simbolizar la responsabilidad del buen gobierno doméstico: Las llaves en la cinta y el perro en la cocina; contra los que son de mal recaudo, aclara Correas. Llave en cinta hace buena a mi y a mi veci$n a$; quiere decir que la buena ama nunca debe descuidar las llaves, símbolo también de la honra, como es el ceñidor de castidad".

Viene igualmente a corroborar este contenido simbólico la siguiente canción popular catalana ${ }^{14}$ : "Mira que fas, Tereseta; / la cabellera t'enganya; / podries esser mestressa, / mestressa de bona casa, / podries dur bon cintó, / cintó, clauer i arracades" (Amades 1969: 630). En este mismo sentido, el que en un texto del siglo XVIII sobre el traje menorquín se diga que "la cadena ó llavero de plata", se correspondía con las mujeres de "menos conveniencias", obedecería al hecho de ser propio de las mujeres "ricas" de allí el llevar las cadenas de oro". Del mismo modo que se constata a través del Padre Colom, a principios del siglo XIX, para la isla de Mallorca ${ }^{16}$.

Por otro lado, y dirigiendo ya nuestra atención, para terminar este apartado, a la ostentosa presencia de oro, o de plata y coral, con que pueden sorprender algunos de los trajes de fiesta tenidos hoy como regionales, dicha riqueza parece derivar de una de las paradojas inherentes al sentir popular. A la definición en sí de la fiesta como un exceso, con

\footnotetext{
${ }^{14}$ Cito por Marí Tur (1973).

${ }^{15}$ Según constató D. Juan Ramis y Ramis, Asesor de la Comandancia General de la isla de Menorca, los "adornos de la cintura" que por el año de 1786 portaban "allí las Mugeres ricas", consistían "en un relox, ó una cadena con un pendiente todo de oro; y en las de menos conveniencias en una cadena ó llavero de plata". Cito por Murillo y Plantalamor (1979: 499-508).

${ }^{16} \mathrm{Al}$ cotejar el vestir que por entonces llevaban las mallorquinas, afirma sobre las "antiguas" que sólo las ricas se ceñían con "cinta d'or", mientras las menestralas "traían cinta de plata" (Véase Mulet 1955: 46-48).
} 
la modificación esencial de los factores económicos derivada de los ritos, tales como las ceremonias religiosas (Beltrán 1991: 30). Paradoja que se subraya en aquellas áreas de economía más deprimida con la localización de piezas-testigo excepcionales, mientras los trajes representativos de otras zonas más florecientes son por lo general más pobres (Cea Gutiérrez 1991a).

Conforme a esta observación, la pobreza reconocida históricamente para las Pitiusas parece encontrar su corroboración en las ricas emprendades con que se vienen complementando los trajes femeninos festivo-ceremoniales que han llegado a nuestros días, y que ya veíamos son equiparables a los de otras zonas deprimidas de nuestro país. Unos paralelismos, por cierto, que vinieron a sorprender por su localización en tierras castellano-leonesas, enclavadas en la zona Oeste de la península, y de la que Luis de Hoyos ya había opinado, tiempo atrás, que se trataba de "la región nuclear y de más arcaicos elementos (culturales) de España" (Hoyos Sancho 1935: 185$)^{17}$.

Se trata de una zona definida como reducto del traje popular, y donde ya hemos visto los modelos indumentarios femeninos pueden mostrarse siguiendo la fórmula antigua a cuerpo, sin mantón sobre el pecho, tal como ocurre en nuestro mismo archipiélago, y tal como lo hacían las variantes dieciochescas que hallamos plasmadas en ciertos documentos gráficos de Ibiza. Si dichos testimonios no se alzaran, con su estrangulamiento en el talle, como un obstáculo frente a la posible ascendencia medieval de las gonelles que han llegado a nuestros días, su correspondiente hechura, de cuerpo corto y largo faldar, sí podría considerarse, aunque tan solo hipotéticamente, recalco, como un rasgo arcaizante.

\section{METOdología ACTUALMENTE UTILIZADA EN LA INVESTIGACIÓN DE LA INDUMENTARIA Y JOYERÍA TRADICIONAL}

Tal como se detalla en el artículo de A. Cea sobre los "Supuestos generales para el estudio de la indumentaria" (2003), para lograr unos resultados objetivos en el estudio del traje y de ahí llegar al conocimiento de la sociedad que lo viste, debe utilizarse una triple vía de investigación: Trabajo de documentación (de archivo y de las fuentes literarias), trabajo de campo (con la doble vertiente de recogida de información oral y localización de prendas y piezas testigo, así como estudio arqueológico, en el que pueden combinarse varios elementos), y estudio iconográfico.

\footnotetext{
17 (Hoyos 1944-1945: 147). Cito por Mateu Prats (1984: 145).
} 
En mi caso, y tras conjugar estas vías de investigación, básicamente me vengo limitado a ir dando a conocer aquellos aspectos que, por uno u otro motivo, podíamos considerar de mayor interés a nivel general, de manera paulatina y progresivamente, según avanzaba la propia investigación. De acuerdo, asimismo, con el rigor científico, he procurado que la propia redacción quedase supeditada al guión argumental trazado por el enlace cronológico de unos documentos con otros; y que la ilustraciones correspondientes no fueran sino su oportuna visualización. Con ello, he venido evitando intencionadamente y en lo posible pronunciarme al respecto sobre un punto u otro, facilitando simplemente al lector la comprensión del escrito, bien fuera con la explicación de los términos específicos, con los datos complementarios que nos podía aportar la consulta bibliográfica, o con aquellas apreciaciones cuantitativas que, a su vez, pudieran resultar necesarias... Precisando, siempre, que lo expuesto no era sino el reflejo ofrecido por la documentación manejada, hasta ese momento en particular.

\section{Estudio documental}

\subsection{Vaciado de archivo}

Entre las diversas fuentes archivísticas, el ibicenco y catedrático de historia Bartolomé Escandell, ya señaló, en su día y, muy concretamente para temas como el que estamos desarrollando, la idoneidad del Archivo de Protocolos de Ibiza (Escandell 1994: 82-83): "Esta documentación notarial, constituye hoy, como es bien sabido y normal -repitiendo sus propias palabras - , fuente especialmente apreciada en cuanto a contenidos [...] que pueden ser objeto de tabulaciones seriales y cuantificadas y tratamiento matemático-estadístico, reveladores de decisivos fenómenos base, sólo advertibles por seriación de sus elementos". Si bien, se trata de una fuente "escasamente explorada", precisamente "por las técnicas de investigación requeridas" y por "la aparente aridez que presenta su lectura", "pero de cuya exploración sistemática cabe esperar importantes revelaciones", tal como en su opinión ya se ha reflejado en nuestros propios trabajos, cuando cita "aspectos destacados que tienen en los protocolos notariales su fuente específica" (ibid.).

Afrontar la siempre lenta y escurridiza labor de vaciado, ordenación y estudio documental es una finalidad que se justifica en sí misma, por lo que supone de recuperación patrimonial. Pero además resulta especialmente atractiva cuando "a través de la realidad virtual de los documentos 
(notariales) se nos abren las puertas, tanto tiempo clausuradas, por las que accedemos al mundo - rabiosamente actual - de lo privado exhibido" (Cea Gutiérrez 2000: 13-16), en este caso, como decía, de los usos que conciernen al vestir. Con lo que, a más del específico trabajo de investigación y del beneficio científico de sus resultados, puede incluso brindarse la posibilidad a muchas familias ibicencas y formenterenses de sentirse retratadas en estos antiguos documentos, como sana curiosidad literaria.

Si a ello se añade que las escrituras públicas no sólo reflejan lo propio de cada momento en particular, sino también lo más ancestral, ya estratificado y heredado, podemos observar la forma con que estos legados se transmitían a las nuevas generaciones, dejando tan sólo en el camino aquellas prendas y piezas que ya hubieran podido caer en desuso, por simples criterios de moda o a causa de su mal estado. Todo lo cual permite que, a través de estas vestigia, se rastree y aflore el estatus social, cultural y económico, los propios gustos, y las relaciones o influencias del exterior (ibid.).

Con todo, no se puede olvidar que los documentos solo reflejan una realidad parcial $($ ibid.). Y que hay también quien ve al escribano o notario responsable de esa transmisión de datos como una figura intermediaria que puede repercutir negativamente en la fidelidad de la información. Aunque muchas veces, y hablo por experiencia, ese papel de intermediario suponga el facilitarnos, incluso, la investigación. Sirva de ejemplo en este sentido, la aclaración de que por mariol se entendía vulgarmente una "carotica", como a su vez era considerado el cambuix ${ }^{18}$. O que el embuit era también la forma con que se conocía a la mitja llana o lana ${ }^{19}$ Dejando ahora aparte todas aquellas especificaciones por las que se nos está

\footnotetext{
${ }^{18}$ Ejs.: API, J. Oliver, 1737, f. 34: "Quatro Birretes de cambrai i cinco caroticas de lo mismo o cambuxos [...] y sinco camisicas de Niño de cambrai" ("villa inferior"); ibid., f. 120: "seys camisas de Muger y seys caroticas o Mariols, Dos toallas de Lienso Ginoves de Muger" ("Parroquia de San Antonio"); API, J Oliver, 1738, f. 7v: "Quatro mariols q. disen" / ibid., f. 20: "Dose caroticas éó Mariols, seys Delgados con randa y los otros de Lienso casero sin randa" / ibid. ff. 47-47v: "Dos caroticas éó cambuxos de cambray buenos y nueve Mariols q. disen buenos", "...seys Mariols q. disen de cambray" / API, J. Oliver, 1742, f. 36: "dos toallas de muger delgadas usadas, dos caroticas o cambuxos delgados" (Quarton de las salinas). Hay que añadir que, en el caso concreto del mariol, existía la duda de su identificación como "casotica", en lugar de "carotica". Por cassot se entendía en Ibiza una "camisola de roba blava gruixada de llana" o "una chaquetilla de mujer", según lo apuntado por el DCVB y el "Vocabulario de las dicciones del léxico ibicenco..." (Pérez Cabrero 1909).

${ }^{19}$ Ejs: API, J. Sala, 1763, f. 149v: "Media lana vulgo embuit"; API, R. Oliver y Castelló, 1786, f. 245: "quatro calsones, dos de lana, o Embuit, y dos de estopa".
} 
diciendo que los modelos indumentarios se correspondían con la "moda forenca" 20 o "usanca de la campanya" ${ }^{21}$...

Finalmente, el conjugar el vaciado del Archivo de Protocolos con el de otros fondos documentales vendrá a redundar positivamente en la visión sobre la indumentaria y la joyería. Por más que esta labor resulte prácticamente inabarcable a nivel individual aún en un prolongado espacio de tiempo. En este sentido, y para nuestro caso en particular, el poder contar con la vasta labor realizada por el recientemente desaparecido D. Joan Marí Cardona, canónigo archivero de la Catedral y Curia eclesiásti$\mathrm{Ca}^{22}$, permite reconocer o corroborar con más detalle ciertos usos en indumentaria a través, por ejemplo, de las prohibiciones eclesiásticas; o percibir la atribución de alguna virtualidad mágica para ciertas joyas, mediante algún testimonio aportado al Santo Oficio.

\subsection{Fuentes literarias}

Ya he hecho referencia anteriormente a la importancia que revisten las fuentes literarias al aludir a La perfecta casada, de Fray Luis de León, así como a los refranes de Correas, cuando tratábamos la cinta o percinta y el clauer. De esta forma lo comprobaba hace ya algunos años (Mateu Prats 1996: 173), valiéndome de los ejemplos literarios más específicos de nuestro contexto cultural que, a este respecto, se ofrecen en el $D C V B$ de Alcover y Moll ${ }^{23}$. Conjugar unos y otros facilita el aproximarnos a la real

${ }^{20}$ Ej.: API, J. Sala, 1766, f. 18v: “...tres faldillas de borel una nueva y las dos usadas, tres de lana buenas, dos delantales de lana y uno azul buenos y uno de luto, onze gambuchos sin randa, quatro flochs que disen de seda, collar en ocho camas de coral y collar gordo de abellotas y sinta de plata de peso de cien libras todo usado y de moda forenza". ("Quartón de Pormany, Partido de San Antonio, baxo de Benimussa, en casa de herederos de Jayme Ribas de Jayme alias Andreu...").

${ }^{21}$ API, A. Arabí, 1710-1711, f. 110: "una gonella de estameña noua negra y un mantell de escot usat, unes manegas de borrell y una gonella ab Cordons alasansa de la Campaña [...]".

${ }^{22}$ Otros investigadores al tratar las Causas Matrimoniales han dado a conocer algunos aspectos de directa incidencia en nuestro estudio (J. y P. Demerson 1993).

${ }^{23}$ El mencionado DCVB recoge en la voz PRECINTA: 'Cinyel' (mall. Eiv); cast. cinto, cinturón. Prest sera ma percinta un cordó (Obras en prosa y en verso de D. Tomás Aguiló, Tomo III. Poesías en mallorquín, Poes. 218. Tipog. Católica Balear, 1883, Palma). Panxeta verge continguda amb sa precinta de plata (G. Maura y Montaner. Aygo-forts 95. Nova Edició aumentada amb poesies. Tip. J. Tous. Palma, 1913. Dones galanes ab les percintes d'or y perles (Obres Catalanes, de Miquel S. Oliver. Ilustració Catalana, Tomo I, 239, Barcelona). 
dimensión de estas manifestaciones, evitando un enfoque parcial, o eminentemente local. Dado que otro artículo ofrece la enumeración de diversas fuentes literarias, nos limitamos aquí a remitir al mismo (Cea Gutiérrez 2002b). Tan sólo recalcar la necesidad de analizarlas con la fría objetividad científica en que vengo insistiendo.

Capítulo aparte merecen los diccionarios e historias generales sobre el traje, igualmente incluidos en este apartado. Dado que la terminología específica, tanto en la lengua vernácula como castellana, contenida en la documentación notarial va, por ejemplo, más allá de la que aportan los diccionarios o enciclopedias en uso, se hace necesario recurrir a los de otros momentos históricos, más o menos contemporáneos con los del documento en cuestión, así como a los glosarios específicos de una u otra materia, que a su vez responden al vaciado de archivo realizado en otros muchos lugares ${ }^{24}$. Sólo de esta forma es posible elaborar los glosarios sobre la joyería e indumentaria llevada en Ibiza, y que resultan imprescindibles para la comprensión de estas dos manifestaciones de la cultura de nuestro pueblo.

\section{Estudio iconográfico}

En lo que concierne a las fuentes iconográficas manejadas en este estudio, y dejando para más adelante el comentario sobre los trajes representados en las mismas, considero necesario exponer el valor que se

${ }^{24}$ El significado que por ejemplo nos ofrecen el $D L L C$ y el $D C V B$ para la voz gonella es el de "tunica llarga cenyida a la cintura duta antigament per homes i dones" o "peca de vestit que duien homes i dones, composta de cos i falda més o menys llarga", respectivamente. Mientras que los glosarios específicos de indumentaria de C. Bernis nos la presentan desde un principio (1283), Crónica de los Reyes de Aragón), con el mismo significado de la saya castellana. Esto es, el nombre que en los siglos XIII y XIV había designado a un vestido de hombre y a un vestido de mujer, y que, a partir de la segunda mitad del siglo XV (dejando aparte el sayo alto), se diferenció para unos y otras bajo las denominaciones de sayo y saya. También de forma similar a como ha ocurrido con la voz saya, algunos documentos y citas bibliográficas se refieren a la gonella como cuerpo y saya, aunque haya llegado hasta nosotros como traje entero. En este último sentido, gonella sería el nombre que se daba en Cataluña, Aragón y Valencia al traje entero que vestía la mujer sobre la ropa interior, o sobre las prendas semi-interiores (como coses y faldillas), que se usaba comúnmente para vestir a cuerpo, pero que se llevaba con otras prendas encima. También como la saya, su corte y aspecto fueron variando a tenor de la moda. Pero así como en el vocabulario castellano saya tenía un significado bastante preciso, gonella podía usarse con un sentido más amplio (Bernis 1962: 91; 1979: 90). 
les viene reconociendo como fuentes para el estudio de la indumentaria de carácter tradicional. Un valor que se subraya al considerar que la documentación gráfica al respecto (pintura, grabado, escultura, códices miniados, retablos, etc), por lo general y fundamentalmente, refleja a personajes de clases superiores (Escandell Bonet 2001: 21).

\section{Siglo XVIII}

1. La fuente iconográfica de menos difusión a nivel general es, curiosamente, la que en el ámbito local viene mencionándose de forma repetitiva. Quizás no tanto por los que básicamente nos hemos limitado a cotejar la indumentaria en ella representada con otros documentos gráficos y escritos, sino más bien por los que se inclinan a ver en ella unos modelos de escasa o prácticamente nula implantación social en la isla. Aunque ello conduzca, lógicamente, a los consiguientes cambios de opinión, como en el caso que nos ocupa.

Estamos hablando, claro está, de las pinturas realizadas por José Sánchez de Ocaña ${ }^{25}$ en el púlpito de la Iglesia de Sant Josep y especialmente de aquella en la que se llama a los feligreses al rezo del rosario (Figura 3$)^{26}$, pues lamentablemente no contamos ya con las que por lo visto mostraban estos mismos modelos indumentarios en el púlpito de la iglesia de Sant Antoni de Portmany, y que desaparecieron durante la Guerra Civil. A pesar de que José María Quadrado ya había manifestado, a finales del siglo XIX, que en un pasaje del pedestal, había quedado una "curiosa prueba" de los trajes usados en aquella fecha de $1769^{27}$.

Según este mismo autor, las pinturas del púlpito de Sant Josep componían, junto con las del de San Antonio y las de la iglesia del Salvador en la capital (de la misma isla de Ibiza), la serie de los quince miste$\operatorname{rios}^{28}$. Mostraba al párroco en actitud de enseñar a sus feligreses el cate-

${ }^{25}$ En 1763 el mencionado artista cobró 318 libras por 44 jornales empleados en pintar las columnas del retablo mayor de la iglesia de San José y los "misteris de la trona" (Marí Cardona 1985: 11).

${ }^{26}$ P. Piferrer y J. M. Quadrado (1888: 1383-1384). (Ver nota siguiente).

${ }^{27}$ Ibid: 1380 al describir la mencionada iglesia de San Antonio comentaba: "la representación de los misterios de dolor trazados en la barandilla del púlpito por inexperto pincel, que en otro pasaje del pedestal, mostrando al párroco en actitud de enseñar a sus feligreses el catecismo, dejó curiosa prueba de los trajes usados en aquella fecha de 1769". (En el comentario pertinente a la iglesia del Salvador -p. 1340 - no se aportan más datos).

${ }^{28}$ Ver nota anterior. 
cismo. Feligreses que, como en el púlpito de San José, portarían los trajes usados por aquel entonces. Dichas pinturas constituyen pues un ejemplo del valor de este tipo de obras para nuestra investigación. Si por criterios artísticos podrían clasificarse en un bajo orden de calidad, "pueden resultar, en cambio, para el etnólogo, de más interés que una primerísima firma" (Cea Gutiérrez 2003: 39).

2. En 1777 , se fecha la "Labradora Yvizenca" de Juan de la Cruz (Figura 5). Dicha ilustración forma parte de la Colección General de Trajes de España (Cano y Olmedilla 1777), de consulta obligada para los investigadores de la indumentaria tradicional, y que el mencionado Juan de la Cruz grabó sobre dibujos de otros diversos artistas; en este caso en concreto, como en el de las otras once láminas correspondientes a las illes Balears, sobre dibujo de Antonio Carnicero.

La temática costumbrista de esta colección de estampas, como ya recogía en otro trabajo (Mateu Prats 2000: 36-37), constituye un reflejo evidente de la transformación de la vida y del gusto que por entonces se estaba produciendo, y que no tardaría en abrir las puertas de un romanticismo precoz. De modo en cierta manera parecido a como ocurría con algunos estudios de paisajes de temática arqueológica, que preludiaban este mismo espíritu, en este último caso a través de la evocación del tiempo y las ruinas (Pérez Sánchez 1986: 398-402).

Conforme a esta transformación en el gusto, es lógico que quien sentía "una particular inclinación por la moda de este período", así como el deseo de extenderla al "tiempo romántico", dedicase ya en 1951 su atención a la referida colección de trajes. Es el caso de A. Mulet, autor de particular interés para nosotros, por haber centrado precisamente su atención en las aludidas doce láminas o estampas correspondientes al archipiélago balear ${ }^{29}$. Para ello partía de la consideración, en cierto modo reticente, de que "incluso el coleccionismo ilustrado puede prestar a la investigación (de la indumentaria) no pocas orientaciones" (ibid.: 2). Por más que, también según su opinión, los tipos que en ellas se mụestran

${ }^{29}$ Las razones que esgrimía para justificar su predilección por la moda de ese período histórico, era que por entonces se había humanizado el arte del vestir, abreviando la ampulosidad y olvidando la rigidez a que se había llegado en momentos precedentes. Todo ello sin conllevar una pérdida del carácter señorial en la indumentaria que hemos venido reconociendo como "a uso de ciudadanos", e impidiendo que lo femenino desapareciera bajo las galas del traje, a su vez admitidas por las mujeres de la propia payesía. Un momento éste, en definitiva, en el que "lo regional" - entendido por este autor como lo popular o castizo- empezaba a comprenderse y tendía a afianzarse (Mulet 1951: 5). 
con el atavío atribuido a Mallorca, Menorca e Ibiza, especialmente los masculinos, respondieran a una visión un tanto libre del autor, pero, en todo caso, "con rasgos más que suficientes en los femeninos para que la fidelidad con el natural no quedase, en lo esencial, alterada o desfigurada" (id.: 4).

Con respecto a las objeciones que algunos puedan formular a la ilustración de Juan de la Cruz por la presencia de un fondo arquitectónico extraño al costumbrismo isleño, hay que constatar que no tiene mayor importancia que la de un detalle ornamental superfluo, que se añadiría posteriormente a la captación del modelo indumentario, el objeto específico de la obra, según un procedimiento artístico bastante común ${ }^{30}$, tal como se atestigua, por ejemplo, en la obra de Pigal ${ }^{31}$.

La importancia de la colección de grabados de Juan de la Cruz Cano y Olmedilla (Madrid, 1777) para el estudio de la indumentaria, reconocida por la investigación actual, queda subrayada por el hecho de que de ella bebieran, ya en el XIX, entre otros, Rodríguez y Albuerne: Colección de trajes que se usan en España (Madrid, 1801), Rouargue, Vázquez, Bradford, Laroque, Doré, etc. (Cea Gutiérrez 2003).

\section{Siglo XIX}

3. "Labradora de la Ysla de Yviza de A. Rodríguez y A. Albuerne" (1801). A comienzos del siglo XIX se fecha la "Labradora" que A. Rodríguez y A. Albuerne eligieron como representativa "De La Ysla de Yviza", en este caso para su llamada Colección de los trajes que en la actualidad se conocen en España (Figura 6); obra en cuestión que igualmente viene siendo material básico de consulta para los investigadores de la indumentaria en nuestro país, como "fuente documental de extraordinario interés" (Casado Lobato 1991: 12).

De las estampas que representan tipos ibicencos - ha señalado, por ejemplo, Nina Ferrer (2002: 13-14) — tenemos que destacar las cromolitografías pertenecientes a la citada colección, una "de les més importants a

${ }^{30}$ Así también se comprueba, por ejemplo, en la que precisamente ha sido considerada como la mejor acuarela realizada con ese mismo interés etnológico por la Escuela Madrileña de Cerámica en tierras salmantinas, y en la que los personajes aparecen enmarcados dentro de una arquitectura mitad serrana y mitad extraña (Cea Gutiérrez 1986: 136-137, Lám. II).

${ }^{31}$ Esta circunstancia puede constatarse observando la acuarela original y el posterior grabado sobre la indumentaria masculina portada por el "Pecheur du Port de st. Antoine". (Ver el grabado correspondiente en Colomar 2002: 28-29). 
l'hora d'estudiar l'evolució de la vestimenta a Espanya" y, por lo tanto, muy copiadas por otros grabadores y reproducidas en otras publicaciones ${ }^{32}$.

4. Finalmente, al Archiduque Luis Salvador y a G. Vuillier se deben aquellas ilustraciones, ampliamente divulgadas, en las que ya se ofrece la imagen de la indumentaria que, básicamente, ha llegado a nuestros días.

\section{Siglo XX}

5. Apéndice del siglo XX para el traje de clauer. Acuarelas de la Escuela Madrileña de Cerámica (1933). Sobre la validez que como fuente de estudio para la indumentaria ibicenca presentan las acuarelas de la Escuela Madrileña de Cerámica de la Moncloa (realizadas en la villa de Santa Eulalia durante el verano de 1933) contamos, ya en principio, con la valoración que de esos fondos han hecho diferentes investigadores del más alto nivel ${ }^{33}$. Entre ellos cabe citar al propio J. Caro Baroja (1986), quien puso un especial interés en señalar que, con independencia de su calidad artística, su valor documental es inapreciable. Del reconocimiento

\footnotetext{
32 Después de citar la obra A. Rodríguez (1801), Nina Ferrer igualmente ha manifestado que "també son molt interesants les cromolitografíes d'Edme Jean Pigal, estretes de la Collection des diverses Provinces de l'Espagne (París, ca. 1825) per la seva qualitat. Pigal va ser un gravador reconegut a Franca, es va caracterizar per un disseny facil d'execucio directa, les seves estampes, normalment estan recollides de la observació directa. Sol representar la realitat tal qual la veu o la recorda, els seus gravats normalment representen personatges del poble, tenia una especil predilecció pels ancians". Para el caso que nos ocupa, la "Paysanne des Environs D'Yvice" (Labradora de las cercanías de Ibiza) de Edme Pigal (1825) sigue nuevamente a las labradoras de Juan de la Cruz y A. Rodríguez, aunque con ciertas diferencias indumentarias. Entre las referidas labradoras de A. Rodríguez (1801) y E. Pigal (1825) se sitúa, cronológicamente, "A Woman of Ivissa" (Paisana de Ibiza). Grabado que fue publicado por Giscard en Londres y año de 1822. Al 1835 corresponde, por su parte, la "Labradora de la Ysla de Yviza" de José Ribelles y Helip, 1832, calcografía a color, a diferencia de las citadas estampas policromadas que responden a la técnica de la cromolitografía, siguiendo nuevamente las observaciones de Nina Ferrer. En todos estos casos, como indicaba, el punto básico de referencia es el grabado de Juan de la Cruz, sobre el que los autores posteriores van marcando las diferencias indumentarias que ellos han podido recoger.

33 En el estudio de la indumentaria resultan fundamentales "en el siglo XIX las pinturas costumbristas de Goya y seguidores, Valeriano Bécquer y otros, hasta enlazar con Sorolla y los acuarelistas de la Escuela Madrileña de Cerámica, desde los años quince del siglo XIX hasta hoy; amén de la importancia de la fotografía con ejemplos tan definitivos como los de la obra de Ortiz Echagüe" (Cea Gutiérrez 2003: 40).
} 
expresado por este mismo investigador hacia la labor llevada a cabo por la mencionada Escuela, sirve a su vez de elocuente ejemplo la forma con que lamentaba el que dichos fondos hubieran estado a punto de desaparecer, por el espíritu saturniano con que España devora a sus propios hijos. Espíritu que consideramos viene ahora también a propósito comentar: "Aquí — decía - no podemos hablar de que haya falta de iniciativas y de impulsos creadores, no podemos decir que sobre tal o cual cosa no se ha hecho nada; no nos faltan, en suma, individualidades creadoras. No vivimos en el ámbito del 'subdesarrollo', con la cultura del 'tercer mundo', en el 'atraso' o cualquiera de los ámbitos que reflejan ciertas expresiones mostrencas que usan muchas personas 'enteradas'. No. Aquí un individuo o un grupo de ellos hace algo con esfuerzo e inteligencia: luego vienen otros (los saturnianos) y lo deshacen".

"Puestos a usar palabras corrientes - continuaba- podríamos decir que 'se lo cargan'. Son como aquellos memorables 'reventadores' de comienzos de este siglo, especializados en asistir a los estrenos, con el seráfico propósito de hacer fracasar lo que fuera: zarzuela, tragedia, comedia, sainete. La cuestión era 'reventar". Suerte que en algunos casos, como el de las acuarelas que estamos tratando, y "gracias siempre a esfuerzos individuales", esa destrucción no se ha llevado a efecto. En esta ocasión, gracias a "personas amorosas que las rescatan y estudian"; que "las ponen ante nuestros ojos y las analizan técnicamente, desde el punto de vista etnológico", en una paradoja aparente: el esfuerzo de un crítico de Arte y de unos jóvenes pintores de hace ya bastantes años, después de ser arrinconado, lo valoran folkloristas y etnógrafos.

Para el caso de las acuarelas de temática ibicenca realizadas en 1933, de muy poco habría servido el que yo misma las hubiera estudiado, tras haberlas localizado en los fondos de la mencionada Escuela madrileña, si no hubiera contado en Ibiza con el apoyo de quien supo valorarlas. Me refiero a Josep María Bassols, catalán amante de nuestra tierra, y quien con su propio equipo se desplazó a Madrid para rescatar del olvido todos cuantos testimonios de ese curso estival pudiera hallar almacenados en dicha institución. De esta manera, lo que un día constituyó el fruto recogido aquí por un grupo de artistas peninsulares, pudo salir a la luz y difundirse en la isla, años después, gracias a la tecnología artística de quien tanto viene haciendo por la cultura isleña ${ }^{34}$.

${ }_{34}$ Santa Eularia 1933 (Acuarelas de la Escuela Madrileña de Cerámica), vídeo realizado por J. M. Bassols. Idea original, texto y asesoria etnológica M. L. Mateu Prats (Eivissa: TV Research, Febrero de 1991, 45 minutos de duración). Una readaptación de este vídeo, de 25 minutos de duración, forma parte de la serie El llegat de les Pitiüses, emitida por TVE2 de Baleares en 1999. 
Puedo decir que, en el estado actual de esta investigación, dichas acuarelas, junto con las reproducciones fotográficas aludidas en la introducción, ponen prácticamente el punto final a los testimonios iconográficos sobre el traje de clauer, aunque dejen abiertos otros muchos caminos, a la hora de intentar discernir cual fue la evolución de las gonelles en Ibiza.

Para dicho propósito, tal como se viene repitiendo, y siempre según el referido criterio metodológico, se hace necesario conjugar los datos extraídos de esos testimonios iconográficos con los de las fuentes de estudio de carácter documental y literario. Además de con todos aquellos posibles vestigios que puedan reconocerse en el llamado trabajo de campo, gracias a la recogida de información oral y a la localización de piezas-testigo.

\section{Trabajo de campo, básicamente en su doble vertiente de recogida de información oral y localización de piezas-testigo}

\subsection{Observaciones acerca del perfil de los informantes}

Dadas las objeciones que cabe reconocer en los propios protocolos notariales, se hace absolutamente necesario señalar uno de los aspectos internos de la investigación que siempre se evita que salga a la superficie. Esto es, el aludir a la precaución con que todo investigador debe aproximarse, en el trabajo de campo, a los informantes. Muy especialmente cuando en estos confluyen ciertas características, tales como un perfil "ilustrado", "pseudocientífico" o, dicho más coloquialmente, "resabiado". Suele ser característico en ellos el extraer conclusiones generales y/o rotundas de algunas pocas lecturas, por lo general de marcado, si no exclusivo, tono local. Todo lo cual, peculiarmente conjugado, e impregnado de subjetividad, suele desembocar en un discurso distorsionado, o, cuando menos limitado, del fenómeno a estudiar. A lo que, en el caso que nos ocupa, suele añadirse la idea preconcebida que aún sigue teniéndose del traje popular.

Mucha más precaución, incluso, ha de tener el investigador en su recogida de información oral cuando queda en entredicho la propia objetividad del encuestado, al atisbarse, o evidenciarse con nitidez, una sistemática predisposición por contradecir ciertas apreciaciones, no ya por su contenido, sino simplemente en función de quien las haya manifestado. De no tener dicha precaución, se corre el riesgo de que también pueda quedar en entredicho la propia objetividad del profesional.

Por otro lado, fruto de la subjetividad puede ser también la forma con que el entrevistador crea interpretar no ya las palabras, sino los "silen- 
cios" o los "gestos" del entrevistado. Dejando constancia que esta observación sobre la capacidad objetiva de interpretación que pueda tener el profesional viene especialmente a propósito en aquellos casos en los que éste ha evidenciado una lectura incorrecta de las mismas fuentes bibliográficas utilizadas.

3.2. Observaciones acerca del período de tiempo que puede abarcar la información oral

Hasta ahora no me había planteado la necesidad de especificar las limitaciones cronológicas con que cuenta la información oral a la hora de tratar aspectos de un pasado no ya próximo, sino lejano. Y es que, por pura lógica, no había imaginado que tal limitación pudiera requerir explicación alguna. Sin embargo, a la vista de los "testimonios orales" que se han creído encontrar ya en el siglo XXI para cuestionar o incluso negar la implantación social que pudo tener un modelo indumentario durante el XVIII, se hace forzoso recordar, tal como ya apuntaba por ejemplo Antonio Beltrán (1991: 27-32), que "el pueblo no tiene memoria histórica", que "hace las cosas intemporales", y que "para él lo más antiguo es lo correspondiente en la generación que ha conocido", por lo que "el tope máximo parecerá eterno y de siempre".

El recurrir a informantes contemporáneos para tratar aspectos que competen a la etnohistoria, tan sólo tiene justificación cuando la información aporta algún dato en sentido positivo. La creencia de que todo era, desde siempre, tal como las dos o tres generaciones que nos han precedido lo pudieron conocer no autoriza a negar lo que la documentación escrita y/o iconográfica de otras épocas venga a reflejar ${ }^{35}$.

3.3. Observaciones acerca del valor representativo de la información recogida

En lo que concierne a la información que el profesional pueda recoger en trabajo de campo, ésta ha de ser lo más cuantiosa y valiosa posible, a fin, también lógicamente, de que pueda considerarse en mayor o menor grado representativa, y que de ella se puedan extraer cuantas más

35 Tal como se ha señalado, el papel del informante es fundamental aunque delicado. Su información nos retrotrae hasta tres o, como mucho, cuatro generaciones, lo que puede derivar en una visión un tanto distorsionada de su realidad en la que a veces se incluyen saltos indebidos y mitologizados (Cea Gutiérrez 2003: 38). 
apreciaciones al respecto. No obstante, hay veces en los que esta recogida de información se limita a unos pocos o, incluso, a un solo informante, por uno u otros motivos.

Si anteriormente también indicaba que por pura coherencia cronológica ni uno, ni muchos informantes pueden negar, por mera apreciación personal, lo que pudo darse en otros momentos históricos, ahora conviene subrayar la comprometida situación en que algunos profesionales pueden llegar a encontrarse si, además de haber podido dar como válidos aquellos otros planteamientos, no han realizado un trabajo de campo mínima o suficientemente representativo. Me refiero con ello, y ahora de forma concreta, a quien el año pasado polemizó sobre el traje de clauer, basándose muy especialmente en la información aportada por un determinado informante, que no sólo negaba prácticamente lo que por las razones aducidas no podía negar, sino que estaba en contradicción con lo que yo misma había recogido en el seno del mismo núcleo familiar y que, paradójicamente, se trataba, además, de mi propia familia ${ }^{36}$. Información, como digo, en sentido contrario, publicada en Ibiza en 1997 (Mateu Prats 1997: 6), y de la que por necesidad tenía que tener conocimiento quien pretendía polemizar sobre el tema.

\subsection{La localización de la prenda o pieza-testigo y el estudio arqueológico}

Huelga señalar la importancia que reviste la localización de prendas o piezas-testigo en el trabajo de campo, especialmente a la hora de materializar los resultados de la investigación con fines expositivos o ilustrativos. Aunque en realidad, la mayor parte de estas prendas, piezas o joyas-testigo suelan constituir el propio punto de partida de la investigación que así se emprende, con carácter retrospectivo, desde lo más reciente hasta lo más lejano y oculto. De esta forma, y por ejemplo, sirviéndome de las fuentes notariales, he podido comprobar en qué momentos y en qué contexto social se va detectando la estructuración en tres cuerpos que hoy caracteriza los elementos religiosos de la cruz y de la joya en la emprendada de oro. O desde qué fecha tenemos constancia de los collares o collarets de este mismo metal. Por no insistir en aquellos testimonios escritos y gráficos que, debidamente conjugados, pueden permitir el

${ }^{36}$ Más allá de las peculiares polémicas que quieran plantearse, no puedo dejar de lamentar la imagen provinciana que, en ocasiones, proyectan sobre el nivel cultural de nuestras islas, distorsionando el reflejo de la profunda investigación, en este caso etnohistórica, que se viene realizando en ellas. 
reconocer en la hechura de la indumentaria femenina, para un periodo u otro, el estrangulamiento o no en la cintura...

Otras veces, sin embargo, y en función del estudio arqueológico, se pretende establecer una vinculación entre el testimonio de la prenda o joya actual y un testimonio arqueológico análogo por simple similitud de formas, sin tener en cuenta el periodo intermedio, documental. Esto trae consigo el riesgo de dar "un salto indebido por el espejismo de unas piezas equiparables en su valor formal, sin tener en cuenta los criterios de continuidad y la interrupción de las mismas en el tiempo". Por más que sea obvio "que existen formas semejantes, préstamos culturales, y que, las más de las veces, las culturas son de ida y vuelta" (Cea Gutiérrez 2003: 41).

El interés por resaltar posibles pervivencias púnicas, fenicias u orientalizantes en las joyas portadas tradicionalmente en Ibiza, no sólo desde punto de vista tipológico o formal, sino también desde el técnico y simbólico, fue uno de mis propios objetivos cuando tenía como meta la obtención del grado en la propia licenciatura de Prehistoria y Arqueología, allá por el año de 1983. Y otros paralelismos diacrónicos de parecida naturaleza fueron los que me llevaron algo más tarde, tanto en mi ámbito insular (Mateu Prats 1985b: 38-44) como en otras zonas (Mateu Prats 1985c: 15-21; ibid. 1985d: 237-261; id. 1985e: 10-15), a seguir postulando a favor del valor de la etnología como ciencia auxiliar de la arqueología, y viceversa, aunque por esas fechas ya comenzara a dejar constancia de una autocrítica al respecto, en clave de humor, y me planteara la confluencia de otras circunstancias, emprendiendo el camino de la investigación de archivo (Mateu Prats 1989).

En todo caso, sería injusta no sólo hacia mi trayectoria profesional y propios criterios metodológicos, sino hacia cuantas opiniones autorizadas me han precedido, así como hacia todos aquellos investigadores del más alto nivel que me han ido honrando con su dirección, apoyo, colaboración, o haciendo de mis escritos elogiosas reseñas, si no dejara constancia del valor que puede revestir en nuestro campo, el estudio arqueológico. Resumiendo, y para concluir, puedo decir que, a diferencia de los que establecen barreras prácticamente insalvables entre el estudio arqueológico y el etnológico, o entre el etnológico y el histórico ${ }^{37}$ o documen-

37 "Otro tema, no menos conflictivo [...] - afirma dicho investigador- es el de lo tradicional, lo bistórico y lo popular en la indumentaria. Solamente decir que se da un divorcio o hiato, para nosotros incomprensible, entre los estudiosos del traje "histórico" y los del "popular". Entre el mal llamado "arte mayor" y "arte menor", lo que equivaldría en nuestro caso al 'traje culto' y al 'traje popular', hay un paso insensible". (Cea Gutiérrez 2003: 35). 
tal, me muestro partidaria de aproximarnos al conocimiento de las diversas manifestaciones del pueblo, como es el caso de la joyería e indumentaria de carácter tradicional, valiéndonos de cuantos medios científicos tengamos a nuestro alcance, y con las prevenciones señaladas para cada vía en particular. Pues pienso - repitiendo lo manifestado por A. Cea-, que todas las vías para el conocimiento del traje, si se miran aisladas, suponen unos resultados distorsionados, pero entre todas ellas puede lograrse una visión más redonda y fiable (Cea Gutiérrez 2003: 42). Desde este planteamiento tengo hoy ocasión de desarrollar el estudio sobre el traje tradicional de las mujeres en las Pitiusas, contando con la dirección de J. Bestard, Catedrático de Antropología en la Universidad de Barcelona y el apoyo de la Consellería de Cultura del Consell d'Eivissa i Formentera.

\section{INDUMENTARIA PLASMADA EN LOS TESTIMONIOS ICONOGRÁFICOS DE LOS SIGLOS XVIII Y XIX}

Una vez presentadas las obras a tratar, y detallada la metodología seguida en mi caso en particular, paso ya a comentar dichas ilustraciones desde el punto de vista de la indumentaria que aquí nos interesa.

1. Pinturas del púlpito de Sant Josep de sa Talaia (1763). Del conjunto de pinturas que decoran este púlpito, la atención etnológica para el estudio de la indumentaria suele centrarse, exclusivamente, en la que se convoca a los feligreses al rezo del rosario. En ella aparecen representados cuatro hombres y tres mujeres, que se dirigen hacia el templo, de forma que una de ellas queda plasmada prácticamente de espaldas (Figura 3). De las tres, una luce sombrero con cinta sobre un cambuix estampado, mientras las dos restantes limitan su tocado a este rostrillo, en ambos casos, según parece, de fondo blanco y guarnición roja, que se anuda con una lazada bajo la barbilla. Básicamente se trata de la toca, o "carotica" sirviéndonos de la terminología aportada por la documentación notarial, que ha llegado a nuestros días enmarcando el rostro, y que aquí cubre también la parte posterior de la cabeza a modo de gorro de recién nacido. Esta particularidad, junto con el hecho de llevar la trenza encintada, implica que el cabello quede prácticamente oculto, tal como era propio de las mujeres casadas o de cierta edad, ateniéndonos al concepto de honor que simbólicamente iba implícito en la familia de los tocados, y por el cual el destocar a alguien se tenía como una de las mayores afrentas (Cea Gutiérrez 1991a): "La doncellez como la prostitución se expresaba 


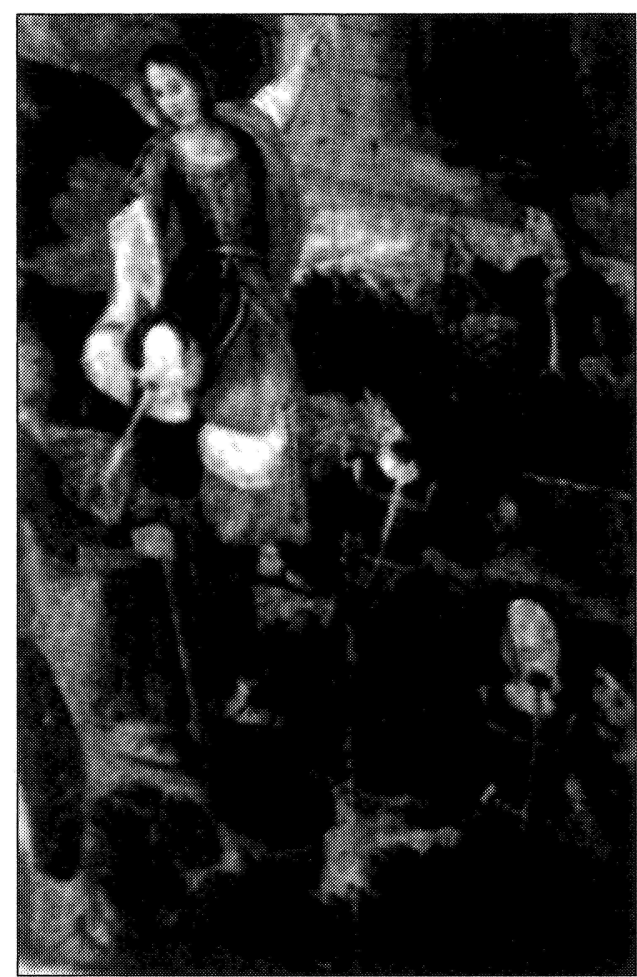

FIGURA 3.-Feligreses acudiendo al rezo del rosario (púlpito de la Iglesia de Sant Josep) ${ }^{38}$. dejando los cabellos al descubierto, sin tocas" ${ }^{39}$. Concepto al que a su vez obedecen los dichos populares recogidos por este mismo autor, y de los que es explícito ejemplo el de "cabeza loca no quiere toca", aunque otro refrán diga "no todas son locas las que veais sin toca", y a lo que puede añadirse "pero casi..." (ibid.). En relación con este contenido simbólico en la ocultación del cabello podría estar, por su parte, el comentario que a finales de la misma centuria dieciochesca hiciera C. González de Posada en las adiciones a las noticias sobre Ibiza y Formentera de Manuel Abad y Lasierra ${ }^{40}$, si bien está aún pendiente el profundizar en este aspecto.

Dos de esas antiguas campesinas —según Ortiz Echagüe al referirse al púlpito de San Antonio- portan sobre la cami-

${ }^{38}$ Ilustración del Grup Folkloric de Sant Josep (1996: 50).

39 Un significativo ejemplo de este hecho lo tenemos en la misma Ibiza a mediados del siglo XVIII a través de uno de los castigos impuestos por el Tribunal Eclesiástico a una mujer que había contraído matrimonio clandestino: "Habrá de oír misa en la Iglesia de San Antonio Abad, y en la de mayor concurso, puesta en el Presbiterio del Altar Mayor con una vela encendida y desmelenado el cabello, descubierta la cabeza" (J. y P. Demerson 1993: 199-200).

${ }^{40}$ Cuando afirmaba que todas las ibicencas "vestían uniformemente y solo se distinguían las casadas de las doncellas en una pequeña diferencia". Precisamente en la de llevar "el pelo en coleta con cinta blanca", conforme a lo recogido recientemente (Grup Folkloric Sant Josep de sa Talaia 1996: 56 y Manonelles 2002: 56), aunque la transcripción manejada de J. Demerson no permite corroborar dicha relación (Demerson 1980: 327-334). Por otro lado, y según nos sugiere Cea, de ser cierta esa primera apreciación, en este caso la diferenciación entre doncellas y casadas más bien podría estar en función del color, que en la propia ocultación del cabello, teniendo además en cuenta el precedente del trenzado. 
sa unas estrechas mangas incorporadas ${ }^{41}$, con botonadura hasta el codo ${ }^{42}$, al menos en la que aparece de cuerpo entero. La cinta roja que cruza horizontalmente la espalda parece unir ambas mangas, pues no se representa en la mujer en mangas de camisa. Todas ellas llevan ajustado gipó o gonella ceñida hasta la cintura, de la que penden unos vistosos flecos. Lo que, ya en su día, me permitió considerar la posibilidad de que por percintas moriscas ${ }^{43}$ se aludiera en la documentación ibicenca este tipo de adorno. "No solo es fácil encontrar en nuestras artes figurativas - exponía al respecto C. Bernis- a personajes vestidos intencionadamente a la morisca, sino que también era frecuente que tuvieran flecos y caireles muchas de las prendas moriscas que describen los textos" (Bernis 1959: 187-209).

Observando el estrangulamiento en el talle de las campesinas reproducidas en el púlpito de Sant Josep, cabe señalar el interés del pintor por destacar con un trazo blanco la cinta de cintura, que la mujer en mangas de camisa ofrece y el aspecto de prolongarse verticalmente por el flanco derecho de la saya. Aunque dicha impresión parece casual, debido quizás a un deterioro de la pintura, y por cuyo motivo la vengo pasando por alto en los últimos estudios específicos (Mateu Prats 1996). En todo caso, la documentación notarial sigue comprobando por estos y otros años posterio-

41 "Debemos subrayar —escribe A. Cea (2003: 16-17) — la importancia de las mangas, concepto que difícilmente alcanzamos a imaginar hoy como prenda independiente y que podía o no aparecer "incorporada" o, por el contrario, como pieza exenta, y esto era así hasta los últimos años del siglo XIX". En lo que respecta a las múltiples citas ofrecidas a este respecto por la documentación notarial, sirvan de muestra las siguientes: API, Hervas, 1692, ff. 53-53v: "de tres en tres anys una gonella de burell, unes manegues y un Capell de Mallorca" ("la Britja"); API, Hervas, 1693, f. 155v: "unes manegas de Cordellat blau" ("Quarto de Santa Eulalia"); AP, Tur Riera, 1703, f. 21: "menegues de xamellot negre" (junto a "gonella de burell", "Quarto de Santa Eulalia"); API, Ximeno 4, 1715, f. 90: "unes manegas de tafeta negra" ("Quarto de Balansat y lloch de Rubio"); Ibid. 1716, f. 140v: "unas manegas de burell" (Ibidem); Ibidem, f. 205v: "unas mangas de paño" (Mayoral de la Torre de Casa en Riambau, llaurador... en lo quarto del Pla de Vila); API, J. Sala, 1747, f. 4v: "unas mangas de Paño setseno buenas"; API, Jasso 220, f. 429: "un par de mangas de anascote, otras idem de pana"...

${ }^{42}$ API, J. Sala, 1763, f. 103: "dos pares mangas de Paño dies y seiseno con dose Botones de Plata pich de martell que disen"; API, J. Sala, 1775, f. 31v: "un par de mangas de paño con ocho abroches de plata redondos"; API, V. Gotarredona, 1803, ff. 2v: "un par de mangas de Paño con doze pares botones de Plata"; ibidem, f. 226: "unas mangas de Pana negra con veinte y seis abroches de plata", "otras de Paño usadas"...

${ }^{43}$ Ej.: API, Arabí, 1708-1710, f. 91v: "una Persinta Morisca" ("qto de Sta. Olaria y lloch de obarqueta"); API, J. Sala, 1763, f. 102v: "una Persinta morisca buena"; API, R. Oliver y Castelló, 1786, f. 197v: "una persinta morisca". 
res el uso de las cintas de plata, o cadenós y clauers ${ }^{44}$, que no sé hasta qué punto podían mantener contactos con las llamadas chatelaines, como el tipo de elemento ornamental dieciochesco por excelencia. Ya que en estos conjuntos de cadenas y llaves llevadas por nuestras campesinas, además de la diferenciación existente, debían pervivir las connotaciones simbólicas inherentes a la mujer casada o dueña del hogar, a que anteriormente ya hacía referencia, y que vienen a corresponderse con el contenido simbólico reconocido en las tocas con que este mismo modelo indumentario ha llegado a nuestros días como "traje de clauer".

C. González de Posada, tras referirse a las colas encintadas, pasaba a decir que, "por lo general", y además de "un tocado finísimo y muchas joias alrededor del cuello", también llevaban "un cinto con llabes de plata pendientes de una larga correa" (Demerson 1980: 327-334). Lo cual, dejando ahora aparte las consideraciones a que nos lleva esta última voz, viene a corroborar la generalización de este elemento en el costumbrismo isleño, como a su vez se evidencia a través de la documentación notarial estudiada ${ }^{45}$.

Con respecto a las características que presenta el faldar de las mujeres representadas en el susodicho púlpito, viene prácticamente a coincidir por su color oscuro o negro con el del jubón o prenda de busto. Razón por la que prácticamente tan sólo documentos como inventarios y encants pueden arrojar luz sobre si se trataba de una gonella en el sentido de vestido entero, o si, por el contrario, se componía de gipó y gonella independientes, entendiendo ahora ésta última voz como faldar. Un faldar que aquí vemos bordeado en su extremo inferior por una franja roja a modo de ribete o guarnición, pero con la que tal vez se quiso representar el borde de la faldilla o faldellín encarnado que podía asomar por debajo de la basquiña o gonella exterior (de modo similar a como ocurre con los calzones blancos, que sobresalen por debajo de los calzones anchos que porta uno de los hombres aquí plasmados). Gonella, por otro lado, de la que no podemos determinar su largura, por la perspectiva desde arriba que se nos ofrece, si bien, quizás gracias al movimiento de la campesina en mangas de camisa, deja a la vista las alpargatas con cintas o cordones sujetando el pie.

Teniendo por último en cuenta la representatividad que la documentación notarial desvela para los delantales azules en este mismo momen-

${ }^{44}$ Entre los numerosos ejemplos, podemos citar: API, J. Sala, 1763, f. 212: "una sinta y un cadenon de Plata con dos llaves de Plata" / API, R. Oliver y Castelló, 1786, f. 112v: "tres cintas vulgo cadenons de plata y un llavero".

${ }^{45} \mathrm{La}$ Voz de correa la he documentado en algunos casos, pese a no adaptarse totalmente a lo reflejado por González de Posada: Ej.: API, O. Boned, 1632-1636, f. 295v: "una corteja de dona"; API, Bermeu, 1634-1640: "la corretja de sañir de dona ab so cordo de seda morat"/ API, J. Oliver, 1738, f. 27v: "Dos correas de sinta de Muger" 
to histórico ${ }^{46}$, se puede sospechar que éstos fueran los que regularmente complementaban a esta gonella amb cordons desde la cintura, y a la que dicha documentación quizás ya se refería a comienzos del siglo XVIII como "gonella ab cordons a la usanca de la Campanya" ${ }^{47}$. Por más que, sin otras puntualizaciones, dichos cordones pudieran referirse, por ejemplo, a los que servían para abrochar el gipó o para unir a éste las mangas independientes $^{48}$. Delantales azules son, desde luego, los que frecuentemente aparecen asociados con las generalizadas gonelles de burell y que algunos documentos describen con 19,12, 9, 8 o un número indeterminado de cordones o "vulgo cordoneras de seda" ${ }^{49}$. Y delantal azul es el que asimismo se representan sobre este mismo modelo en las acuarelas de 1933

* de la Escuela Madrileña de Cerámica, y que, como decía, constituyen el apéndice del siglo XX para el traje de clauer.

Otra pintura del púlpito de San José prácticamente ignorada desde el punto de vista etnológico que aquí nos interesa, es la que se refiere a la Adoración de los pastores (Figura 4). En ella, las dos mujeres que figuran en el ángulo inferior muestran también una indumentaria merecedora de estudio. La que lo hace en primer término, con una toca a modo de

${ }^{46}$ Ejs: API, Botino, Botino, 1678-1679: "un devantal blau vell" / API, Tur Riera, 1703-1706, ff. 9-9v: "un vestit co es Capell, manegues, Gonella de burell, davantal de mitja llana per el gasto cotidiano y un de Mallorca blau ..." / API, Ximeno núm. 4, 1715, f. 91: "un davantal blau de llana"/ Ibidem, 1715-1716, f. 140v: "dos davants blaus de mitja llana" (doc. relataivo a un labrador del "Quarto de Balanzat" y lugar "de Rubio") / Ibidem, f. 205v: "un devantal de estam blau" (doc. correspondiente al "Mayoral de la Torre de Cassa en Riambau, llaurador en lo quarto del Pla de Vila") / API, J. Rosell, 1726, f. 47: "dos devantals blaus" / Ibid. f. 119: "dos devantals, un blau y lo altre de escot negre" / API, J. Oliver, 1737, ff. 68v, 120 y 123v: "un delantal Asul" / API, J. Oliver, 1742, ff. 13v y 36v: "un Delantal Asul" / Ibidem, f. 54: "Dos delantales asules, otro de lana" / API, J. Sala, 1747, f. 114: "Unas Basquiñas de Borel, con Delantal asul de Mallorca ..." / API, J. Sala, 1763, ffs. 65-65v: "Dos delantales asules y dos Delantales de lana" / Ibidem, f. 133v: "Dos Delantales asules uno de lana" / API, M. Roselló, 1770, f. 96: "dos delantales, el uno asul y el otro de lana"...

${ }^{47}$ API, A. Arabí, 1710-1711, f. 110: "una gonella de estameña noua negra y un mantell de escot usat, unes manegas de borrell y una gonella ab Cordons alasansa de la Campaña".

${ }^{48}$ Tal como ya se constata en el ejemplo reproducido en la cinta anterior.

${ }^{49}$ Ejs.: API, J. Sala, 1763, f. 79v: "una Basquiña de Borell con dose cordones de seda" / Ibidem, f. 133v: "una Basquiña de Borel con ocho cordoneras" / Ibidem, f. 169v: "una Basquiña de Borel con dies y nueve cordones vulgo cordoneras de seda", "otra Basquiña de Borel con doce cordones de seda" / Ibidem, f. 189: "una Basquiña de Borel con nueve cordoneras" / API, R. Oliver y Castelló, 1786, f. 96v: "una Basquiña de Borel con sus Cordoneras" / Ibidem, f. 131: "dos Basquiñas de Borel, una nueva con sus cordoneras y la otra usada"... 


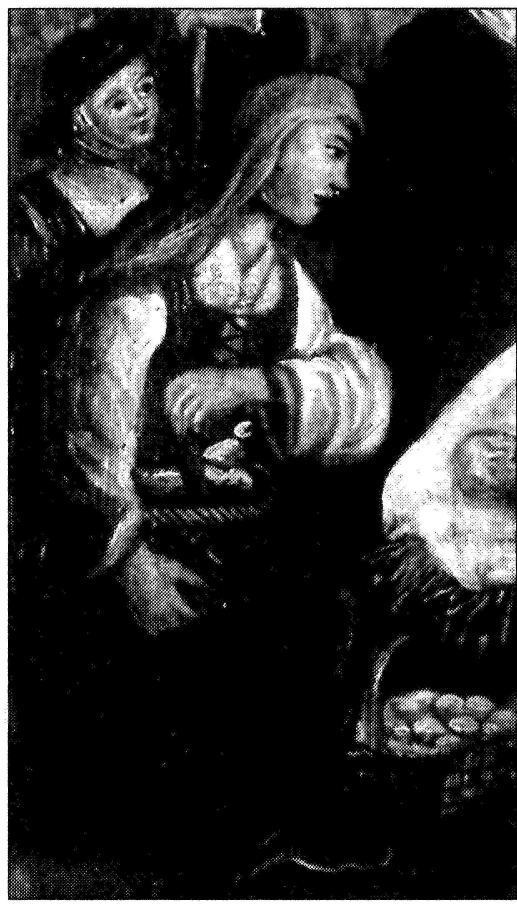

FIGURA 4.-Fragmento de la Adoración de los pastores (Iglesia de Sant Josep) ${ }^{53}$. velo cayendo sobre sus espaldas y en mangas de camisa, gasta un gipó ${ }^{50} \mathrm{O}$ facet $^{51}$ encarnado, quizás de "cordellat vermell", según apuntan varios documentos notariales ${ }^{52}$, con abrochadero de cordón en zig-zag, tal como veremos repetirse en las láminas a estudio. Mientras que de cintura para abajo gasta un faldar o saya de color oscuro, que cabe suponer se complementaría con un delantal, oculto por la cesta de ofrendas.

De la mujer reproducida en segundo plano, tan sólo podemos ver el busto, que viene a ser la representación frontal de una de las gonelles que veíamos de espaldas en la pintura correspondiente al rezo del rosario. Concretamente, de la que portaba sombrero sobre cambuig y mangas independientes sobre las de la camisa. Podemos ver aquí nuevamente la cinta o cordón de seda bordeando el casco del sombrero, como a su vez varias veces refleja la documentación

${ }^{50}$ Del gipó femenino de color encarnado la documentación notarial nos ha ofrecido varios ejemplos en distintos géneros y localizados en diversos contextos sociales: Ejs: API, Bermeu, 1614-1619, f. 69v: "un cos de gipo de tafeta encarnat"; "vila damunt" /API, O. Boned, 1651-1654, f. 305: "una gonella de mescla blaua guarnida de pasamano y un gipo de tafeta vermey guarnit de pasama" /API, O. Boned, 1632-1636, f. 125v: "altre gipo de girasol vermell de dona" /API,Hervas, 1692 f. 48v: "un gipo de Cordellat vey de color vermey" / API, A. Arabí, 1708-1710, f. 94: "dos Gipons, un de dona de estameña vermella" ("Qto de Balansat y lloch dit lo camp vey")...

51 En su acepción como justillo.

52 Ejs: API, O. Boned, 1651-1654, f. 303v: "una gonella de estameña burella y un fasset vermell" ("Pere riusech, Cath. palerm")/API, Guasch, 1685, f. 90: "un faset de cordellat Vermell Usat" /API, Hervas, 1691, f. 177v: "un facet vell de Cordellat vermey y un gipo vey"; "davant lo pou de la Torre noua" /Ibidem, f 197: "dos fasets vermeis" ("qto. del Pla de Vila") / Ibid. f. 232v: "un facet vermey de grana" /Ibidem, f. 265v: "un faset, Camisola y manegues de Cordellat vermey nou tot en una pessa" ("qto. del pla de Vila"); API, A. Arabí, 1708, f. 38: "un fasset de Cordellat vermey usat" / Ibid. f. 108v: "un faset vermey de cordellat usat"...

53 Fotografía G. Mateu Prats. 
notarial ${ }^{54}$. Y podemos también advertir cómo dicho sombrero se lucía de forma ladeada sobre el cambuig, que ahora creemos ver atarse bajo la barbilla con la cinta roja que asimismo parece constituir la guarnición que enmarca el rostro.

La extrema similitud existente entre las prendas de cabeza y busto aquí representadas por José Sánchez de Ocaña con respecto a las que se muestran en el grabado de Juan de la Cruz y otros afines, que paso ahora a comentar, se ha de tener muy en cuenta a la hora de considerar su fidelidad con el natural, o cuando se plantean dudas acerca de su representatividad en el pasado de Ibiza, ya que no es sólo este autor, sino otros varios, los que se hacen eco de las mismas.

2. "Labradora Yvizenca" de Juan de la Cruz (1777). De acuerdo con A. Mulet (1951: 5), fue por estas fechas, el último tercio del siglo XVIII, cuando se advirtió "una especie de reacción contra las modas importadas en su mayoría de Francia y en parte de Inglaterra"; cuando la propia Corte española, y con más razón el pueblo, se inclinó por el "gusto nacional"

${ }^{54}$ API, Botino, 1681, ff. 92 y ss: "...que lo dit nogura dega donar a sa nora [...] y de tres en tres anys gonella, capell y manegas y espardeñas y per raho del vestit de plor una gonella de borell mallorquí noua y un devantal de mija llana de mallorca un capell boleado unes manegues negres de xamellot o sarja unas sabatas negras mes per lo Crex..." / API, Botino, 1683, f. 59v: "un capell de dona nou ab un cordo de seda" / API, Guasch, 1685 f. 13: "dos capells lo un de dona ab cordo de seda y lo altra de home usat" / API, Hervas, 1693, f. 155v: "un sombrero ab una veta de seda" / API, A. Arabí, 1708-1710, f. 92: "Dos cordons de capell de seda usats" , "dos Capells de dona ab un cordo lo uno de seda tot nous" / Ibid. f. 103v: "...la mia gonella de burell (...), un capell ab cordo de seda (....)" / API, Ximeno núm. 4, 1715-1716, f. 204v: "un Capell de dona ussat ab cordo de seda" ("llaurador... en lo quarto del Pla de Vila") / API, J. Oliver, 1737, f. 9: "...el sombrero de hir a Misa" / Ibidem, f. 62v: "Dos sombreros de Muger el uno bueno con su cordón y el otro viejo" / Ibidem, f. 124: "tres sombreros de Barcelona de ombre y otro de muger con su cordón de seda" / API, J. Oliver, 1738, f. 47v: "Dos sombreros de Muger el uno con su cordón y el otro sin el" / Ibid.f. 132: "un sombrero con culo a lo antiguo" / API, J. Oliver, 1742, f. 13v: "un sombrero de Muger con su cordón de seda" / Ibid., f. 54: "un sombrero con su cordón. de seda a la moda" / Ibid. f. 83v: "un sombrero de Muger con su cordón de seda bueno" / API, J. Sala, 1747: "un sombrero de Muger con su cordón de sdea negra / API, J. Sala, 1763, f. 79v: "un sombrero nuevo de Mallorca" (acompañando una "Basquiña de Borell con doce cordones de seda" y otra de lana) / Ibid, f. 96: "un cordón de sombrero de muger de seda" / Ibid. f. 129: "dos sombreros de hombre, uno de muger de Barcelona"... A todos estos ejemplos, y a otros muchos más que, lógicamente, quedan sin reseñar, hay que sumar el comentario de finales del siglo XVIII sobre el arraigo de esta prenda en la isla (Demerson 1980), así como la información sobre los sombreros de Mallorca aportada por Vargas Ponce (1787). Para momentos posteriores, la reseña del Archiduque Luis Salvador (ibid. 1869-1891). 


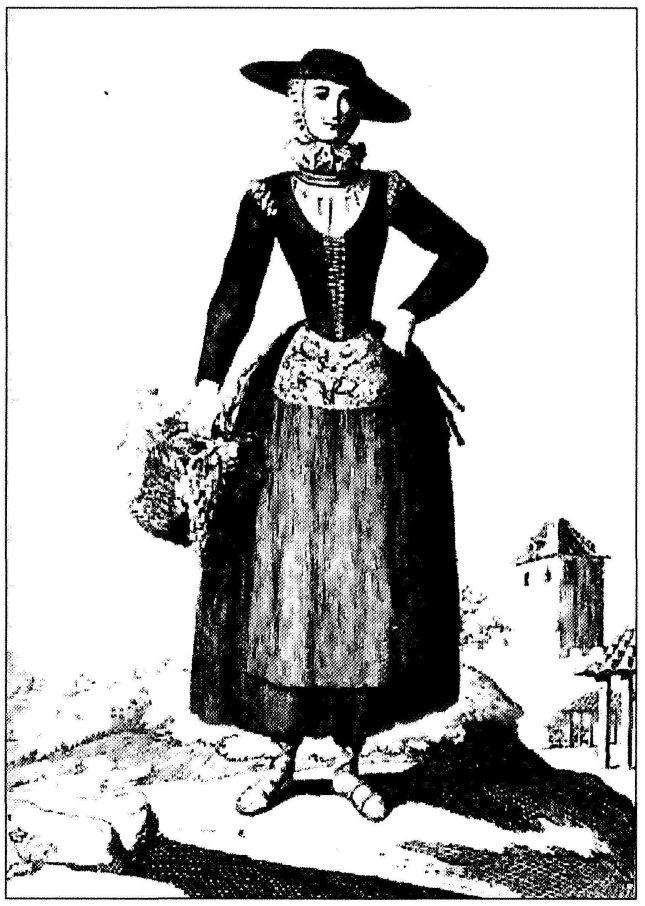

FIGURA 5.- "Labradora Yvizenca" de Juan de la Cruz (1777). que, según él y en resumidas cuentas, no era sino "la suma de los gustos regionales", esto es, de lo popular o castizo, transcribiendo sus propias palabras.

Sabemos que a los extranjeros que venían a España por estos años les llamaba la atención, y encontraban a las mujeres muy favorecidas, cuando vestían para ir por la calle o a la iglesia el traje característico del país. Traje que, de manera similar al que muestra la "labradora yvizenca" de Juan de la Cruz (Figura 5), consistía en un jubón ceñido al cuerpo con mangas largas y estrechas, basquiña negra sobre brial o guardapies, que podían dejar ver el tobillo, además de delantal y mantilla, negra o blanca, sobre cofia (Leira Sánchez 1991: 18). Esto es, el tocado de red plasmado para los tipos madrileños por Goya o Bayeu y que parece haber quedado fosilizado en la red o gandaya que hoy caracteriza el tocado femenino en Cataluña (Casado Lobato 1991: 13).

Sin embargo, en lugar de dicha cofia, esa "labradora yvizenca" lleva el mismo rostrillo o cambuix que ya lucían las mujeres representadas en el púlpito de Sant Josep, tocándose además con el mismo tipo de sombrero. Las mangas incorporadas son también prácticamente iguales a las de aquellas otras. Si bien ahora, y tal como ya indicaba, lleva una ostentosa gorguera sobre el cuello, mientras sobre la saya lleva ya el devantal de mostra que hoy todos conocemos.

Precisamente, este grabado es el documento que, al menos por el momento, nos ofrece el primer testimonio de dicho delantal, ya que los protocolos notariales consultados hasta ahora hablan de delantales bordados a partir de $1803^{55}$ y de delantales "de muestra" desde el de

55 API, V. Gotarredona, 1803, f. 225v: "dos delantales bordados"; API, 1839, f. 18: "dos delantales de lana, uno bordado"; Ibid., f. 34v: "dos delantales, el uno bordado 
184856. Año en el que un inventario en el término de San Juan, registra "seis delantales de lana, tres de ellos bordados con seda y los otros con lana", junto con "otros nueve delantales de indiana", que al parecer se correspondían con "duce basquiñas de lana" y siete "de tela de algodón" 57 .

En lo que respecta a la referida gorguera, o más específicamente lechuguilla, ésta constituiría uno de los rasgos en que debía pensar Mulet cuando escribió que las láminas de Juan de la Cruz dejan constancia de que "aún por entonces estaba vigente la riqueza del barroco" (Mulet 1951: 14). Ya que las lechuguillas, o colls de llatuguilla, cuya primera documentación se fecha en el siglo XVI ${ }^{58}$, y que tanta trascendencia tuvieron en la segunda mitad de ese siglo y a comienzos del XVII ${ }^{59}$, habían pasado a ser incluso del uso de las labradoras en esta última centuria, según

y el otro inferior" (en la almoneda, f. 46: "un delantal de lana bordado, 52 reales"); API, 1845, f. 289v: "tres delantales bordados".

${ }^{56}$ API, 1848, f. 62v: "dos delantales (de lana) bordados y otro sin muestra". API, Zoilo Boned 279, 1850, f. 201v: "dos delantales de lana uno de muestra y otro sin ella".

57 API, 1848, ff. 353v-356, Inventario de los bienes de Francisca Ferrer, viuda de Antonio Mary Murenu vecina de la Parroquia de San Juan en la Ysla (de Yviza)", practicado en la "hacienda con sus correspondientes casas sita en la referida parroquia de San Juan conosida por Can Toni Mureno de Cas Cavaller".

${ }^{58} \mathrm{El}$ primer doc. Reconocido por C. Bernis (ibid.) se fecha en 1529-1533. En un principio serían de pequeño tamaño y posteriormente se irían agrandando.

59 B. Escandell, en su estudio sobre el siglo XVII en Ibiza y Formentera, al tratar las influencias indumentarias en la villa de Ibiza, hace constar que un folleto oficial publicado en 1746, se exponía que en dicha Villa vivía "nuevecientas personas de todas las edades que visten a la española, cuyo idioma hablan perfectamente" (Cfr. Macabich 1966-67, I: 462; ver también Vargas Ponce 1787). Según dicho autor, "el aserto reviste un grado de generalización que hace presumir el siglo barroco isleño como el momento inicial y progresivo de tales incorporaciones en el vestido". ¿Cuál era - se pregunta más adelante- el vestido masculino y femenino en la Villa antes de la época barroca? ¿Cuáles eran las prendas foráneas que pudieron irse adoptando luego? ¿A qué sectores sociales conquistaron los cambios y mimetismos? "Ésta de la indumentaria - asimismo observa - es faceta del pasado nada fácil de reconstruir y de procesar historiográficamente, circunstancia explicativa de que no abunden los estudios al respecto" (pese a lo cual remite en este punto a J. Puiggarí 1890 y a M. Herrero, "Estudios de indumentaria española de la época de los Austrias" Hispania LI, 1953, 185-214). Tras ello pasa a enumerar las dificultades que encierra su investigación (algunas de cuyas observaciones ya las hemos recogido en el apartado metodológico) y finalmente concluye: "Quede ahora registrado, en todo caso, que la idea de permeabilidad local a influjos foráneos en la época barroca, parece debe incluir un espacio mental en que encajar una eventual penetración de modos externos, formas foráneas y hábitos sociales incluyendo cambios en la indumentaria. Y quede abierto semejante registro a deseables, futuras precisiones sobre las formas y el proceso al respecto" (Escandell Bonet 2001: 620-621). 
lo afirmado por Puiggarí (ibid.: 209-210). Extremo, éste, al que podrían apuntar ciertos inventarios ibicencos contextualizados en beretats o propiedades rústicas, fechados entre 1609 y 1620 , aproximadamente ${ }^{60}$.

Pese a todo, a la hora de comentar la lámina de la "labradora ibizenca", y sin negarle, como veíamos, veracidad o fidelidad con el natural, el mismo A. Mulet opinaba que, en ella no se había recogido ni con mucho, "la riqueza folklórica de la época", ya que, en su opinión, no sólo se hubiera podido sacar mejor partido, sino dar una idea más aproximada del traje femenino —que le extrañaba que aquí no fuera la típica gonella—, al tiempo que echaba en falta algún indicio sobre la tradicional emprendada. Por el contrario, no demostraba sorpresa alguna ante el calzado, del que se limitó a señalar su fabricación personal y su sujeción al "uso antiguo". Al tiempo que describía la prenda de busto como "un corpiño muy escotado por delante, que deja al descubierto la camisa de hilo de lino" (Mulet 1951: 14-15, comentario a la lámina 41).

Para otros lugares, y mucho más recientemente, en los estudios que hemos podido consultar sobre esta misma Colección de trajes, los investigadores evitan emitir juicios personales (Cea Gutiérrez 1983: 183-194). Circunstancia que responde a la ya repetida premisa científica de no poder desestimar los testimonios de otros tiempos, por el simple hecho de que éstos no se adapten a la idea, o supuesta antigüedad, que hoy se pueda tener de ésta u otra manifestación de la cultura popular.

Por otro lado, y en lo que concierne a la ausencia de joyas aludida por A. Mulet, si observamos con detenimiento el grabado de Juan de la Cruz, por debajo de la citada gorguera parece advertirse la presencia de dos o tres hilos de collar. Hilos que, de ser de coral o cristal, denotarían una tendencia a formas antiguas, y de los que la documentación notarial nos dice que a veces podían colgar extremos de carácter mágico protector, como manetes ${ }^{61}$ y branquetes $^{62}$ del mismo coral, o religioso, como

${ }^{60}$ Conforme a la trascendencia de esta moda en la segunda mitad del siglo XVI y comienzos del XVII, se identifica en inventarios en la ciudad de Ibiza y en beretats o propiedades rurales de la misma en el primer cuarto de esa última centuria, referidos a los últimos momentos del XVI. Ejs: API, Bermeu, 1609-1613, f. 449v: "dos colls de home de costanca un pla y lo altre de llatuguilla"; "quarto de pormany"; API, Bermeu, 1614-1619, ff. 335v y 336: "un coll de lletuguilla de olanda", "altre coll de ollanda de llatuguilla"; "lloc de forada del quartó de Portmany".

${ }^{61}$ Ej.: API, Ximeno núm 4, 1716, f. 206: "Un Collaret ab deset grans de Crestay, quinse grans de Coral, dos manetas de Coral encastadas de plata y una pedra de llet"; ("Quarto del Pla de Vila").

${ }^{62}$ Ej.: API, J. Oliver, 1737, f. 106: "un collar con granos de cristal y coral con una Branca de coral" ("Qua. de Pormany"). 
joietes $^{63}$ y medallas de plata $\mathrm{O}$ peltre ${ }^{64}$, en algunas ocasiones "de hechura" o silueta recortada.

Se ha de tener presente que "el siglo XVIII aparece escindido en dos mitades. Durante la primera se mantienen formas arcaizantes y predomina aún el sentido religioso y protector sobre el concepto de joya de ostentación" y sigue vigente la joya-utensilio, como los pomos de perfume. "A partir de la segunda mitad, quizá por las corrientes de la Ilustración, se miran con desprecio piezas y elementos protectores (higas, castañas y otros amuletos) y caen en desuso materiales antes primordiales, como la plata, el coral o el azabache ${ }^{65}$, postergados por los materiales dorados y el oro [...], casi con una única finalidad, la de la joya como ostentación" (Cea Gutiérrez 2003: 41).

3. Labradora de la Ysla de Iviza de A. Rodríguez y A. Albuerne (1801). Como indicaba, se trata de una versión del grabado anterior, en la que se ha suprimido el fondo arquitectónico y donde la figura aparece en diferente postura de cabeza y brazos, si bien sigue portando una cesta con productos de la viña (Figura 6). Entre los rasgos indumentarios, el cambuig al parecer ligeramente fruncido de aquella otra da paso aquí a una ornamentación más voluminosa, mientras la lechuguilla se representa con más detalle y amplitud. También como en. la ilustración de Juan de la Cruz, lleva el mismo tipo de sombrero y sobre la camisa, jubón o gipó ceñido hasta la cintura, con abrochadero frontal de cordón en zig-zag, que a su vez queda más abierto sobre el pecho. Las mangas incorporadas son por su parte iguales, aunque resulte más difícil precisar el sistema de unión al jubón, que, en aquel otro, era también de cordón.

${ }^{63}$ Ej: API, J. Sala, 1763, f. 102v: "Un collar de seis ylos de coral con dos Joitas, y una ramita de coral con encaste de Plata".

${ }^{64}$ Ejs: API, J. Oliver, 1737, f. 68v: "un collar con algunos granos de coral y de cristal, con una Medalla de plata y una virgen del Pilar de Peltre". / API, J. Sala, 1763, ff. 189-189v: "un collar de Bellotas de christal y una medalla".

${ }^{65}$ Dejando ahora aparte los rosarios de azabache, de los que tenemos documentación en Ibiza desde principios del siglo XVII (Ejs.: API, Bermeu, 1614-1619, f. 30v: "un rosari de atzabeja negra ab grans grosos" / API, Hervas, 1693, f. 201: "un rosari de atzabeja", La Marina), son aquí especialmente significativos los siguientes registros, aunque vayan referidos a la indumentaria infantil: API, Bermeu, 1645-1646, f. 248v: "una coteta de estameña burella $a b$ maneguetes de domas negre ab una maneta de etzabeja", "villa davall" / API, O. Boned, 1651-1654, ff. 256v-257: "un vestidet de raxa blaua de miñona de mitg any ab una maneta de atsebega y un [...] de or [...] cadenetes de plata sobredauradas una baula de cos de guya, altra de baula de cadena" (J. Armadams). 
De cintura para abajo, el motivo ornamental del devantal de mostra es sumamente similar, con diferencias de tonalidad que no podemos pre-cisar. En este grabado de Albuerne sobre dibujo de A. Rodríguez, la parte inferior de dicho delantal es negra como el gipó, mientras en el de la labradora de aquel otro, esa parte inferior parece ser más clara que la de la saya, de tonalidad parecida o igual al de la prenda de busto. Finalmente por calzado, el mismo tipo de sandalia ligada a los tobillos que prácticamente deja al descubierto todo el pie.

Sorprende especialmente el tono rojo del faldar exterior, que la documentación notarial suele constar para las faldillas o faldellines -en principio prendas interiores pero que podían lucirse levantando la saya ${ }^{66} \mathrm{ci}$ mera- aunque algún que otro registro hable incluso de basquiñas ${ }^{67} \mathrm{o}$ gonelles encarnadas. La representatividad en los usos isleños del traje de esas faldillas o faldellines, por lo regular de estameña o bayeta encarnada, o bien de grana, así como la identificación entre éstas y las gonelles o basquiñas, o entre las mismas y los vestidos ${ }^{68}$ que a veces desvela la documentación manejada, en última instancia vendría a explicar la utiliza-

66 "El caráctẹr de falda interior que tenía esta prenda - escribe C. Bernis- se pone de manifiesto en el curioso Tratado sobre los pecados que se cometen en el vestir, escrito por Fray Hernando de Talavera en 1477. Según este autor, las faldetas se inventaron porque cuando las mujeres 'se ocupan en servicios y oficios humildes, alzan y remangan las faldas de la saya por que no se les haya de ensuciar, y para guardar la honestidad y quedar cubiertas las piernas suplen allí las faldetas de vil y grueso paño'. El fraile se lamenta a continuación del lujo desplegado en las faldetas, habiendo sido inventadas para uso tan humilde. Un pasaje de la Tragicomedia de Lisandro y Roselía, publicada en 1542, demuestra que las faldetas conservaron su carácter de prenda semiinterior: 'medio desnuda medio vestida, los pechos de fuera, con un disimulado descuido, en faldetas como éstas, no hay tal para provocar la luxuria a los hombres". "Aunque algunos textos del siglo XV parecen confundir vasquiña y faldilla - comenta en otro apartado-, propiamente hablando existía una diferencia entre ambas. La faldilla era una falda interior, la vasquiña era exterior y se hacía con menos tela [...] Según los patrones que da Juan de Alzaga en 1580, la vasquiña era en esa fecha una falda cerrada con poco vuelo, y el faldellín era abierto y con más vuelo. Esta misma diferencia establece Covarrubias en 1611 entre ambas prendas: 'las faldillas, faldetas o faldellín son la mantilla larga que traen las mujeres sobre la camisa que sobrepone la una falda sobre la otra siendo abiertas a diferencia de las vasquiñas que son cerradas y entran por la cabeza" (Bernis 1962: 107, en Faldetas, faldillas, faldrillas).

${ }^{67}$ API, J. Sala, 1747, ff. 59 y 206: "una Basquiña de estameña colorada" (anteriormente "una Basquiña de estameña negra"); "una Basquiña de estameña colorada, otra de estameña negra y un jubón de chamelote negro usado"). También: API, J. Oliver, 1737, f. 123: "una Basquiña de niña de tafetán colorado vieja con randa", entre "un coletillo de vaeta colorada" y "otro coletillo colorado")

${ }^{68}$ API, 1835, f. 49: "dos vestidos vulgo faldellins, uno encarnado y otro de lienzo". 
ción como prenda exterior de estas faldetes, al igual que parece haber ocurrido con el faldelli blanc (Mulet Ramis 1993: 237).

Sobre lo manifestado por C. González de Posada acerca de las "sartas de corales" y "joias alrededor del cuello", en este grabado tan sólo creemos poder reconocer algunas vueltas de collar bajo la gorguera, al igual que creíamos advertir en el grabado anterior. No se aprecian joyas como colgantes de los mismos, ni llaves pendientes desde la cintura. Sin embargo, en el mismo año de 1801 en que se publicaron los grabados de Albuerne diversos registros notariales siguen dejando prueba del uso de las "sintas" y "llaveros", con llaves y joyas, todo de plata, no sólo en Ibiza sino también en Formentera, junto con collares de coral o de coral y cristal, además de rosarios de coral encadenados de plata y de botones o abro-

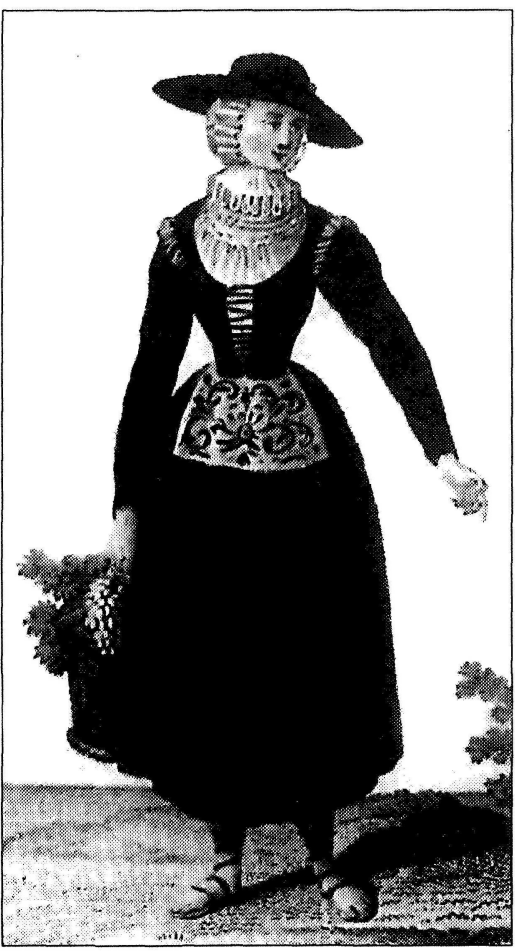

FiguRA 6.- "Labradora de la Ysla de Yviza" de A. Albuerne. ches también de plata, de "golpe de martillo" o "llanos", sin que falten los "Santos Cristos", de plata u oro y otras piezas de este último metal ${ }^{69}$.

${ }^{69}$ Ej.: API, J. Juan, 1801, ff. 31 y 31v: "una sinta y llavero con cuatro llaves y tres Joyas todo de plata", "Otra sinta y llavero con quatro llaves y una Joya, Todo de plata". "Un collar de cristal y coral con ocho Joyas", "otro collar de coral granos chicos de nueve hilos", "unos Rosarios de coral encadenados de plata", "doze abroches de lo mismo", "un par de mangas de paño negro con treinta abroches de plata golpe de martillo", "otro par de pana con otros treinta abroches de lo mismo llanos" y "Cuatro pares abroches de oro medianos" ("Pueblo de San Jorge, Lugar de Benimussa"). Ibidem, ff. 199-200: "Un collar de coral, un cadenon, dos pares abroches medianos, el uno de oro, veinte y cuatro golpe de martillo, un Santo Cristo mediano también de plata" ("Ysla de Formentera, lugar de la Mola)". Ibidem, ff. 239-241: "Un Santo Christo de oro mediano, cuatro pares abroches de lo mismo, una sinta y llavero de plata, veinte abroches de lo mismo golpe de martillo, unos rosarios encadenados de lo mismo, un collar de coral con cuatro johitas tambien de plata, dies hilos coral granos chicos, [...] un Santo Christo de plata mediano" ("Ysla de Formentera, Lugar de la Mola"). Ibidem, ff. 247v-248: "Un Santo Christo de plata mediano, quarenta y ocho abroches golpe de martillo, dos pares de llanos, un llavero con cuatro lla/ves, dos joias 
De lo manifestado por C. González de Posada, en el grabado de Albuerne tampoco se aprecian las plumas o flores en el sombrero, y tanto el largo de la saya como el tipo de calzado dejan a la vista más que la punta del pie (lo único que mostraban las ibicencas al bailar según dicho autor). Pese a todo, y muy especialmente de cintura para arriba - a excepción de la gorguera-, parece ser una clara prolongación de las gonelles representadas en el púlpito de Sant Josep. Esta suposición adquiere más consistencia considerando lo que por estos mismos años escribía A. G. de St. Suauveur (1808). Según su testimonio, si bien el extranjero que por primera vez veía a las mujeres de estas islas no podía dejar de admirar la belleza de sus cabellos, que caían más debajo de la cintura (cito por Colomar 2002: 20), tampoco era infrecuente constatar que llevaban una cola de vaca añadida a los mismos; uso que dicho autor dudaba se extendiese más allá de las Pititusas (ibid.: 24). Pese a ello, sabemos que en Menorca igualmente recurrían a los rabos de vaca con su penacho inclusive como extravagante postizo para alargar sus cabellos.

De esta forma, el encintarse la trenza - tal como se aprecia en las mujeres representadas en el púlpito de Sant Joseph y en la "menestrala" menorquina de Juan de la Cruz (Mulet 1951: 13, lám. 9) ${ }^{70}$ se ha entendido como un hábil recurso para disimular ese tipo de trucos encaminados a alargarlas, pues se consideraban tanto más elegantes cuanto más se aproximaran a los talones. Dicho ideal estético vendría así a paliar para el mencionado Hernández Sanz el no poder exhibir los cabellos "por abundantes y hermosos que ellos fueran" (Cito por Amades 1969: 94, nota e).

4. Otros grabados. A juzgar por las similitudes básicas con los grabados de Juan de la Cruz y de Albuerne que todavía presentan en 1822 y 1825 la "Woman of Yvissa" y la "Paysanne des Environs D’Yvice" reproducidas respectivamente por Giscard (véase Colomar 2002: 24-25) y Pigal (ibid. 26-27), poco habría ido evolucionado en Ibiza la indumentaria fe-

medianas, todo de plata, cuatro pares abroches de oro, nueve hilos de coral, dos rosarios encadenados de plata" ("Quartón del Llano de la villa, morador y vesino en los molinos de agua del Quarton de Santa Eularia")...

${ }^{70}$ En la p. 13 figura el siguiente comentario: Lám. 48 y novena. Menestrala. ¿De dónde? No se dice, pero vamos a situarla en Menorca. Aclara en francés, mujer de obrero. Menestrala es, mejor, la mujer del menestral [...] Va bastante bien vestida y hasta señorea [...] El pelo sujeto en trenza que va encanutada, como tiesamente vendada, al uso menorquín. Todo muy acomodado a una menestrala, como casi escatimada a la dama. Menestral y menestrala alcanzaron consideración social, y lo que se dice de Menorca puede aplicarse a Mallorca e Ibiza". 
menina desde finales del siglo XVIII hasta esos primeros años del siglo $\mathrm{XIX}^{71}$. Motivo por el que nos limitamos aquí a señalar la apariencia de delantal bordado sobrepuesto a otro de mayor longitud, que ofrece la ilustración de Giscard, así como la clara constancia de las joyas de oro en la de Pigal.

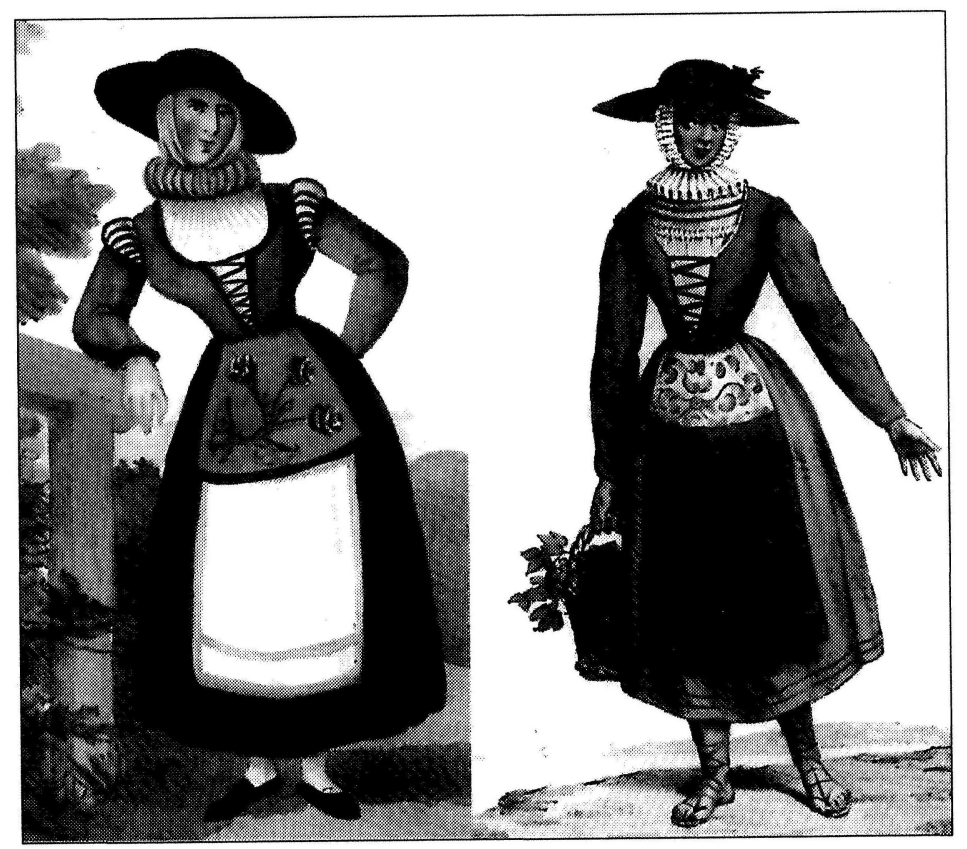

FIGURAS 7 y 8.- "Woman of Yvissa" (1822)

y "Paysanne des environs d'Yvice" (1825) de Giscard y Pigal.

Pese a esa marcada continuidad de formas, ya en 1832, la "Labradora de la Ysla de Yviza" de José Ribelles y Helip (1832) (Figura 9) rompe en el tocado con lo reflejado en esos ejemplos anteriores, tanto en lo que se refiere a la tipología del propio sombrero, como a la desaparición del cambuig, que ya da paso al pañuelo atado bajo la barbilla, por más que tampoco se disponga sobre la cabeza de la forma que hoy conocemos. Colocación del pañuelo, por cierto, que el dibujante puso especial interés en recoger, dada la forzada postura de perfil con que se representa la cabeza, mientras el cuerpo lo hace de frente. De las ilustraciones

${ }^{71}$ Como decía, dejo para otra ocasión el comentario sobre la ropa de dichos grabados. 


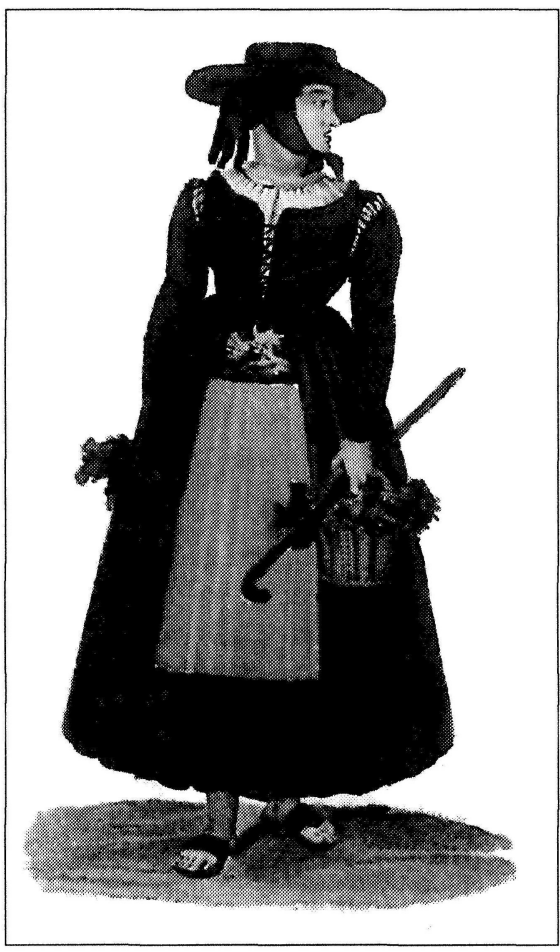

FIGURA 9.- - "Labradora de la Ysla de Yviza" de J. Ribelles y Helip. manejadas desde 1777 es también la primera que deja de constatar la lechuguilla o golilla sobre el cuello, aunque prácticamente por lo demás, y en líneas generales, siga ateniéndose al modelo de Juan de la Cruz.

En lo que concierne al faldar y a la parte inferior del devantal de mostra, cabe señalar que se muestran con unas tonalidades significativamente representadas en la documentación notarial a lo largo de los siglos XVII y XVIII: el color musco, morado", y el de "mella tendra"73, aunque éste último no lo hayamos constatado para prendas como el delantal que aquí nos ocupa. Colores de los que incluso algún que otro ejemplo notarial prácticamente nos muestra su asociación ${ }^{74}$.

Junto a la denominación de "mella tendra" tomada del entorno, viene aquí a propósito comentar dentro de la gama entre los azules y morados, el color "de romaní"75, el "de frígola"76 y el de "viola boscana"77, que otros informes notariales re-

72 API, O. Boned, 1632-1636, f. 354:"una gonella de drap morada ab son gipo de xamellot morat tot nou" (más adelante) "unes manegues de drap morat".

API, O. Boned, 1651-1654 (1654), f. 192v: "una gonella de estameña morada".

API, Botino, 1678-1679, f. 94: "una gonella de sarja de color morat, un Gipo de fil y seda de dona nou [...]" ("Raval de la Marina").

API, Hervas, 1692, f. 74; "una gonella de camell musco de dita viuda y un rebosillo de gorgoran" (patrón, la Marina).

API, A. Arabí, 1708-1710, ff. 66-67v: "una gonella de estameña musca".

API, J. Rosell, 1729, f. 63: "una gonella de estameña musca".

73 API, 1609, f. 64v: "una gonella de mescla ab rivets color de mella tendra".

${ }^{74}$ API, O. Boned, 1632-1636, f. 354:"altre gonella de mescla verda ab son gipo de xamellot morat".

75 API, Bermeu, 1614-1619, f. 30:"una gonella de mescla color flor de romaní".

${ }^{76}$ API, O. Boned, 1632-1636, f. 159v:"gonella de mescla color de frígola ab rivets".

7 API, J. Rosell, 1729, f. 93v: "una gonella de tafetan color de viola boscana". 
gistran también para las gonelles. En este sentido cabe igualmente decir que "la denominación empleada para el estudio del color en la indumentaria difiere de la utilizada en pintura y heráldica, basándose la nuestra sobre todo en elementos zoomorfos y fitomorfos y, en menor cantidad, minerales" (Cea Gutiérrez 1991a).

\section{REFLEXIONES SOBRE LA EVOLUCIÓN DE LAS GONELLES EN IBIZA}

Ya hemos visto que en los atuendos tradicionales españoles se advierten variaciones a través de los siglos, de acuerdo con las diferentes oleadas de modas que desde las villas y ciudades penetraron en los pueblos, produciendo cambios y sustituciones en ellos, aunque el proceso de asimilación o aceptación fuese largo (Casado Lobato 1991: 11). Del retorno a hechuras de otros períodos que a su vez se produce en esa evolución es un claro ejemplo la moda imperio, por la que a finales del siglo XVIII la inspiración greco-romana condujo al corte bajo el pecho, con la consiguiente supresión del estrangulamiento en el talle. Es decir, tal como viene siendo característico en la gonella negra, al menos como ha llegado hasta el momento actual. En este aspecto, cuando Antonio Mulet comentaba los doce grabados realizados por Juan de la Cruz sobre dibujos de Antonio Carnicero, correspondientes a las Baleares en el último tercio del siglo XVIII, tras señalar que aún por entonces estaba vigente la riqueza del barroco, observaba como ya comenzaba a apreciarse la tendencia "a una espiritualización que había de estilizar grandemente el gusto imperio" (Mulet 1951: 4). Más adelante, al referirse, concretamente, a la indumentaria femenina en la isla de Ibiza, continuaba diciendo que "conservada la gonella durante el XIX hasta nuestros días, la moda imperio dio además a la ibicenca nuevas galas, que no oscurecieron las anteriores..." (ibid.: 14). Esta observación, que dicha así parece no afectar a la configuración de la gonella, puede adquirir otra dimensión si tenemos en cuenta el abismo que parece existir entre las aludidas representaciones sobre el traje en Ibiza, y la forma que hoy conocemos. El abismo que distancia a unas de otras queda especialmente manifiesto por el comentado estrangulamiento en la cintura de las representaciones manejadas, y la desaparición de éste - con el consiguiente desplazamiento hacia arriba- en la hechura de la "actual". En consecuencia, parecería no sólo razonable, sino lógico, el explicar esa modificación por el efecto de la moda imperio, que se dejaría sentir por los años en que se detecta el cambio. A favor de esta interpretación están, además, otras varias circunstancias, que a su vez vienen a fortalecer el reconocimiento de esas fuen- 
tes gráficas como representativas de los modelos que se llevaron en la isla:

- Las coincidencias básicas que, además del citado ajustamiento, existen entre la indumentaria femenina en el púlpito de San José y en el grabado de D. Juan de la Cruz y similares (ver, a propósito, la semejanza básica existente entre cambuixos y sombreros, además de entre las manegues independientes) (Figuras 10 y 11).

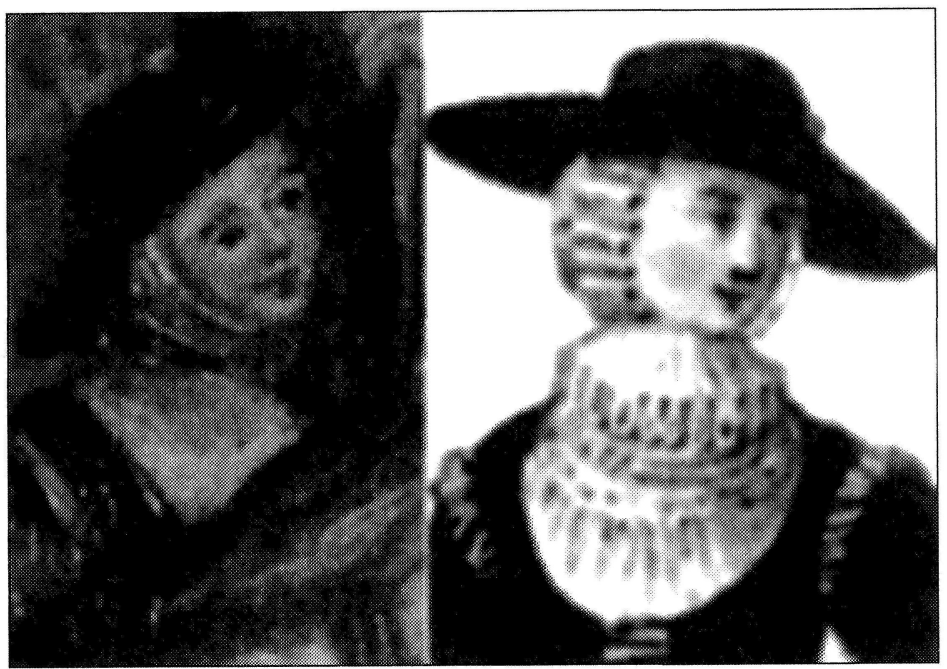

Figuras 10 y 11.-Detalles de la mencionada pintura de Sant Josep (1763) y de la "Labradora de la Ysla de Yviza", de A. Rodríguez y Albuerne (1801).

- El que tanto dichos cambuixos como sombreros -independientemente de su evolución morfológica-, y manegues incorporadas, sean perfectamente paralelizables con los que ha mantenido la tradición en la isla.

- El que las diferencias detectadas entre ambas representaciones parezcan encontrar su clara correspondencia, tipológica y cronológicamente, en la documentación notarial ibicenca estudiada hasta el momento. Este es el caso de las "cordoneras" que muestran sobre la cintura varias de las figuras femeninas del púlpito de San José. Y este también es el caso del "devantal de mostra" que aparece en la "labradora" captada por D. Juan de la Cruz y otros diversos artistas. Devantal que, por cierto constituye hoy uno de los más representativos elementos de la indumentaria tradicional.

La especial correspondencia que se aprecia en la documentación notarial entre las gonelles de burell $i$ cordoneres de seda con el clauer, parece que no se da, en cambio, en el púlpito de San José (1763). Si bien 


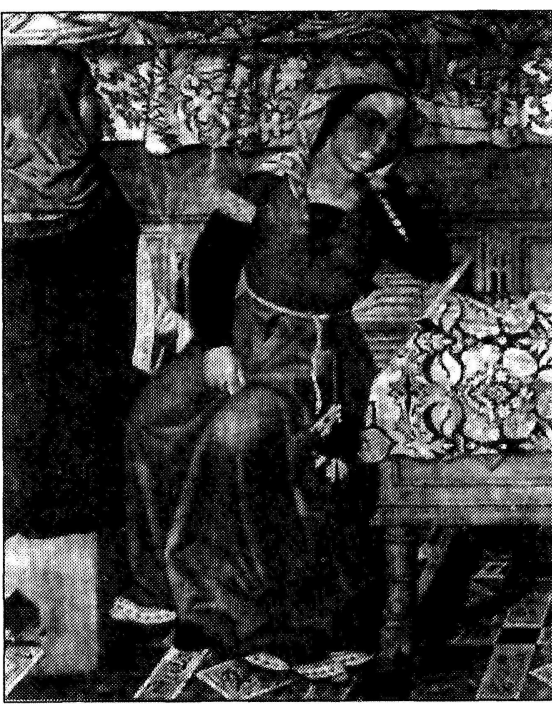

Figura 12.-Mujer con toca, gonella y clauer representada en el retablo de San Esteban (taller de los Vergós, siglo XV) ${ }^{78}$ resulta razonable pensar que las referidas "gonelles de burell con cordoneras de seda", identificadas en la documentación notarial normalmente junto al clauer, son las que José Sánchez de Ocaña plasmara en la susodicha trona, con cordones o flecos sobre la cintura.

Llegados a este punto, y tras haber admitido para el caso concreto de Ibiza el posible uso de las prendas prietas hasta la cintura, antes de que a la payesía llegara el impacto de la moda imperio, resulta altamente significativa la semejanza morfológica que los referidos cuerpos ceñidos presentan con el de una gonella del siglo XV, reproducida en el retablo de San Esteban del Taller de los Vergós (Museo de Arte de Cataluña); gonella en cuestión que, además, luce clauer colgando de la cintura (Figura 12).

La similitud que se patentiza entre las prendas representadas en esas fuentes gráficas se hace especialmente evidente al observar:

- La abertura en "V" delantera del cuerpo, apreciable, tanto en la representación del citado retablo, como en el grabado de Juan de la Cruz.

- La hechura ajustada y hasta el color oscuro de las mangas independientes o complementarias, que vemos repetirse en dicho retablo ${ }^{79}$, en el púlpito de San José y en el grabado de Juan de la Cruz. De forma

78 (Lozoya 1975, III: 417; Bernis 1979, I: 79, lám. XIII, fig. 23).

79 A diferencia de los otros dos testimonios posteriores, que muestran camisa bajo el jubón o gipó, corpiño o facet, en este caso puede reconocerse el cos como prenda interior, cuyas mangas complementarias, ajustadas y oscuras, se ven bajo las mangas de la prenda exterior. Precisamente algunos corpecicos no tenían por misión más que ser sostén de unas mangas, tal como se observa en algunos inventarios del siglo XVI (estudiados, igualmente, por C. Bernis), que nos hablan de mangas "con su corpecico" o de "corpecicos con mangas". La relación de esta prenda con las mangas se conocía a través de ciertos informes notariales ibicencos de principios del siglo XVII, y contextualizados en el ambiente de "dalt vila" (API, Bermeu, 1614-1619, f. 69v: "un cos y manegues de domas carmasí", "altra gonella ab cos y mangas de tafeta vert"; Ibidem, fol. 80v: unas faldetes de domas vermell ab cos y manegues"). 
análoga a como se conserva en la gonella negra conocida por todos nosotros.

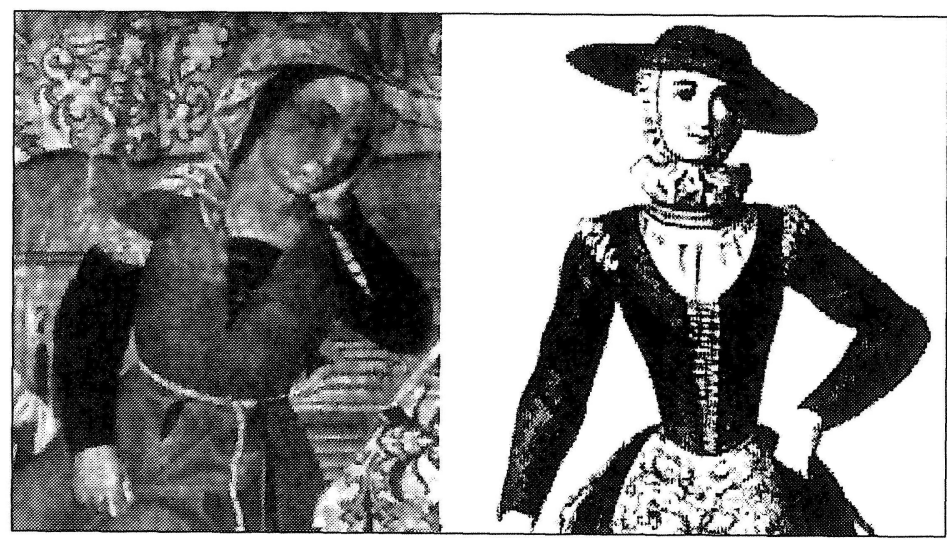

FIGURAS 13 y 14.-Detalles de la referida gonella del siglo XV y de la "labradora" recogida en el grabado del XVIII de Juan de la Cruz Cano.

Apoyándonos científica y coherentemente en estas semejanzas, la mujer representada con toca, gonella y clauer en el mencionado retablo del siglo $\mathrm{XV}$, sí podría situarse, al menos conceptualmente ${ }^{80}$, en uno de los escalones evolutivos que pudieron conducir a los modelos posteriores que, por todo lo expuesto, se llevarían en Ibiza durante la segunda mitad del siglo XVIII (Mulet Ramis 1993: 223). Para aproximarnos al grado de implantación social de que pudieron gozar, contamos con la información contenida en los Protocolos notariales.

Del referido grabado de D. Juan de la Cruz y otros testimonios afines no puedo pasar por alto la presencia de la lechuguilla en el cuello que presenta esa "labradora ibicenca", sin duda en traje "de vestir". Adorno que evoca el "gual.lareto" que ha quedado fosilizado en la indumentaria popular de las mallorquinas, cuando éste adopta la forma de un abanico plegado. Y que nos lleva a recordar cómo los colls de llatuguilla ${ }^{81}$ ya habían pasado a ser del uso de las labradoras en el siglo XVII. Siglo durante el cual Covarrubias dijo al respecto que este nombre se daba a los cuellos o cabezones de lienzo o de holanda "haciendo ondas semejando a las hojas de lechugas encarrujadas" (Covarrubias 1984 [1610]).

\footnotetext{
${ }^{80}$ No entra en el propósito de este artículo el adentrarnos en consideraciones profundas sobre el proceso evolutivo que pudieron seguir unas u otras prendas.

${ }^{81}$ Ya veíamos también que el primer documento reconocido por C. Bernis se fecha en 1529-1533.
} 
Los grabadores - se ha afirmado- recogieron "variantes de una moda que ya por entonces, y en manos de estamentos plebeyos, se tenía por pasada y llamaba la atención como algo exótico" ${ }^{\prime 2}$. De acuerdo con ello, la labradora ibicenca reflejada en el grabado que estamos comentando, sería la que, a juicio del que la captó, mostraba, en ese momento, una indumentaria representativa de la payesía isleña. Por más que nos sorprenda seguir hallando este elemento ornamental hasta 1825, con la representación de Jean Pigal. Unos años, por otro lado, para los que la documentación consultada ha dejado de hacerse eco de los colls de llatuguilla, y tampoco se registran sinónimos al respecto, si bien esta circunstancia puede modificarse al proseguir la investigación, y no podemos descartar la posibilidad de que dichos cuellos se aludiesen bajo alguna de las voces que aún quedan por identificar. De entre ellas cabe citar, para el XVIII, el filempua ${ }^{83}$ o tela clara y transparente que, hablando en propiedad, se realizaría con un fil per $p u a^{84}$, y que se utilizaba para este y otros tipos de prendas ${ }^{85}$, aunque, según apuntan varios documentos, se aplicaba en Ibiza a una de ellas en par-

82 "Bien claro queda — prosigue Cea Gutiérrez (1983: 190) - en la explicación que el propio Cano y Olmedilla da en su obra cuando afirma: "En el primer volumen de esta colección, que se da de dos en dos estampas, saldrán los trajes más usuales de la Pleve del Reyno, y en el segundo los raros de la Nobleza con toda la Monarquía. Esta dicotomía social del vestido se refleja con insistencia desde el siglo XVI en diversos documentos donde el comitente aclara que desea se haga 'al estilo del pais' o 'como se usa en este lugar', si el gusto del cliente está anclado en patrones tradicionales; por el contrario, querrá que se haga 'a uso de ciudadanos' si pretende formas de novedad".

83 B. Mulet en su estudio sobre Els Teixits a Mallorca (Mulet Ramis 1979: 7-8), dice que era uno de los de lino que se hicieron allí, del que el diccionario nos dice que se hacía con uno o dos hilos por pua. Fue empleado desde el siglo XV hasta el XIX o más, y su uso fue uno de los más abundantes en toda esa isla, configurando diferentes prendas de vestir, ropas de ajuar doméstico y religioso. Según la preparación, "la filempua era crua, blanquejada, i tenyida de blau", si bien también había "filempua llistada i mostrejada". Para nuestro caso, los Capitols de Política y Bon Govern de la illa de Ivica, de 1655, dejan constancia de cuatro calidades, "tot per graus conforme lo fil", que por aquel entonces recibían las siguientes valoraciones: desde los "sinch sous" la cana de "la grossa", o la menos valorada, hasta los "vuyt" de "la més prima" de todas (Capitols publicados por Fajarnés 1930: 56).

${ }^{84}$ Para aclarar la etimología de este nombre, el mismo Mulet Ramis (1979: 7-8), explica que "els telers tenen un conjunt de dues barretes o llistons horitzontals i paral.lels, a l'altura de les mans, que formen la pua del teler. Cada barreta se troba dividida en peces verticals de canya o de fusta per en mig de les quals passen els fils de l'ordit. Si sols hi passa un fil, el teixit s'anomena Fil-en-pua; si n'hi passen dos, se diu Fil de dos-en-pua. De la primera varietat la documentació és nombrosa; de la segona n'hi ha ben reduïda col.lecció de referencies".

85 Tal como asimismo constata B. Mulet (1979), el filempua "se destinava a peces d'indumentaria, que eren: ballanties, colls, davantals, descuits, maneguins, 
ticular $^{86}$. Circunstancia que ha permitido haya venido formulándome la pregunta de si por filempua se aludía a una toca (considerando que éstas pueden conocerse por el nombre de la tela que las configura ${ }^{87}$ ) o al cuello que venimos comentando, pese a no tratarse de un tocado.

De especial interés para el estudio iconográfico, es, por su parte, el saber, al menos, la existencia de otra ilustración sobre la indumentaria femenina portada en Ibiza. Se trata —alega A. Mulet (1951: 14)—, de una acuarela realizada por Chiesa, que estuvo algún tiempo en Ibiza. Tras este comentario pasa a decir -ignoramos sobre qué datos- que dicha gonella "en el siglo XVII era de gran adustez, conservado con alguna pompa más en el XVIII y que en el XIX, manteniendo lo esencial de la línea, admitió pañolones y echarpes, cintas y otros adornos...". Por esta información nada nos permite saber cómo se representa a esa gonella en la línea de cintura, que aquí especialmente nos interesa.

En la reseña sobre la indumentaria ibicenca de 1860 por A. Flores ${ }^{88}$, la citada gonella negra se describe como un sayo, que ceñía y oprimía las formas de la mujer, "desde la cintura - y recalco esta palabra - hasta los pies", que de esta forma quedaban "perfectamente cubiertos". El "corpiño", en su opinión, no era "tan gracioso como el xipó de las mallorquinas", si bien lo lucían menos que aquellas, porque (ya) cubrían sus hombros "con un pañuelo de colores festoneado y lleno de adornos".

En la descripción que hiciera, por estos mismos años, el Archiduque Luis Salvador, se dice que las payesas ibicencas llevaban "una especie de gipó o armilla negre ajustat al cos", y que "les faldes, anomenades gonelles", llegaban hasta el suelo. Apreciaciones que, en el primer caso, parecen estar igualmente indicando un estrangulamiento en el talle. Es decir, tal como a su vez parece mostrar la campesina que aparece, en mangas de camisa en una de las litografías aportadas por este mismo autor $^{89}$. Característica que no es posible apreciar ni en la ilustración

mocadors, sotabarres, tovalloles de cap i vels". En Ibiza, la documentación notarial muestra su aprovechamiento en diversas prendas de la casa y de indumentaria. Entre las primeras se cuentan, por ejemplo, pavellons de llit y cobricaixon; entre las segundas, cambuixos, vels y tovalloles, al parecer a su vez "de cap".

${ }^{86}$ API, Guasch, 1683-1684, f. : "Una filampua noua"; API, J. Sala, 1747, f. 114v: "tres filsampua q disen"; API, 1763, ff- 129 y 169v: "Un filempua"...

87 Según se ha encargado de constatar por ejemplo Bernis, entre otros autores.

${ }^{88}$ Cito por E. Fajarnés Cardona (1995: 145), y A. Colomar (2002: 26).

89 "Ibiza desde el Puerto" (1874). Lámina en color, litografía según dibujo original del Archiduque Luis Salvador y realizada bajo su dirección por el pintor Thomas Ender. Extraída de Las Antiguas Pitiusas (ed. de 1982). 
específicamente dedicada por él mismo a la indumentaria femenina, ni en las que da G. Vuillier, ya que un chal o mantón ha pasado a ocultar el busto y la línea de cintura.

$\mathrm{Si}$ negar la incidencia de las modas en los estratos populares es otro de los argumentos que se han expuesto para negar una evolución del traje popular, resulta ya de por sí nuevamente revelador el comentario que a su vez hiciera el Archiduque Luis Salvador sobre el "gran capell de feltre" que, por aquel tiempo aún guardaban algunas ancianas como recuerdo de su juventud, pero que por entonces ya "cap eivissenca gosaría lluir públicament [...] peca tan pasada de moda". Comentario que no constituye sino una prueba más del seguimiento de las modas en los estratos populares, aunque fuera con las lógicas limitaciones económicas y de forma ralentizada.

Por otro lado, es difícil de comprender cómo se puede negar dicha incidencia, con la consiguiente evolución, precisamente para aquellos períodos en que el traje que hoy se estudia como objeto de museo cumplía su función vital, y se habla, en cambio, de evolución para la indumentaria popular del siglo $\mathrm{XX}$, cuando ésta ya habría iniciado su proceso de fosilización. ¿Es que lo único que interesa es negar la existencia de un determinado modelo indumentario? ¿Quizás porque se da por hecho que ese modelo en cuestión responde a modelos valencianos, o mallorquines? ¿Es que alguien de los que así lo han llegado a apuntar ha aportado alguna prueba al respecto? Por otro lado, ¿a partir de qué momento podemos adscribir como propias "de" las variantes indumentarias que se vienen conociendo con el apelativo de "regionales"? Es más ¿Podemos realmente reconocerlas, en algún momento, como tales?90 Son muchos los matices que hay que saber reconocer al respecto, y muchos los comentarios que confluyen en este cauce, para poder desarrollarlos aquí. Baste con señalar una prioridad científica: la de investigar etnohistóricamente la evolución seguida en cada zona en concreto, y así poder determinar dónde unas u otras prendas se registran por primera vez, dónde se mantienen por más tiempo y dónde han podido quedar fosilizadas como características de la región. Eso nos permitiría, al menos, tener una idea aproximada de los caminos seguidos por las diversas corrientes de la indumentaria.

90 "Cuando una comunidad, por pequeña que sea —escribe Cea Gutiérrez (2003: 34-35)-, fija unas prendas con un carácter determinado y las utiliza como identificativas frente a otras comunidades nace el 'traje del país'. En este sentido hablamos de regionalismo e incluso de localismo [...]. El regionalismo en el traje no es un problema moderno, sí, y muy distinto, el de traje regional, pero éste deriva de causas, por lo general, de carácter político, que han forzado, limitado y uniformado distintas indumentarias, distorsionándolas hasta el estereotipo". 
1. "Gonella amb cordons a la usança de la Campanya". ¿El "traje de clauer"?

Tal como ya he venido indicando, recientemente ha vuelto a brotar una polémica que parecía olvidada, al menos para la mayoría, si no práctica totalidad, de los interesados en la materia, y especialmente para los que nos mostramos activos partidarios del estudio etnohistórico que, en este caso, concierne a la indumentaria. Pese a ello, y dado que esta opción implica una visión abierta y sin prejuicios, es fácil hacerse cargo de lo difícil que puede resultar romper con los rígidos y limitados esquemas que aún se vienen repitiendo. Comprendo que pueda no entenderse la evolución que haya podido sufrir el traje en Ibiza. Incluso para los que, como yo, se han doctorado y especializado en estas materias, es necesaria una especial y dúctil objetividad a la hora de reconocer, y de aplicar en Ibiza, el significado de las voces sobre el traje contenidas en la documentación manejada. O cuando los testimonios iconográficos vienen asimismo a sorprendernos con la plasmación de modelos alejados conceptual y morfológicamente de los que hoy conocemos, y que algunos aún siguen teniendo como claras pervivencias de épocas muy lejanas.

Se da, no obstante, la paradoja de que quienes aún parecen moverse dentro de planteamientos ya superados en otros ámbitos, y que se muestran proclives a repetir hipótesis como si fueran sentencias, pueden interpretar, o querer presentar, el rigor científico como fruto de la inseguridad, y las novedades que venga a aportar la investigación, como producto de una postura sesgada y hasta lanzada (por más que dicha investigación se base en documentos notariales y testimonios gráficos).

Lamentaría que estas palabras se interpretaran como prepotentes, precisamente cuando vengo insistiendo en la humildad que ha de caracterizar a todo investigador (cuya palabra ya indica que se está intentando averiguar aquello que aún no se conoce), y que no tengo reparo en ir precisando, y hasta en corregir, si viene el caso, lo que pude creer o apreciar en otros momentos de mi trayectoria profesional. Me refiero especialmente con ello, tal como ya indicaba en un principio, al propio giro dado en mi labor de investigación, tras haber iniciado el estudio de archivo e iconográfico, y que, por ejemplo, me ha llevado a demostrar el fuerte grado de representación social de que gozó el clauer en el costumbrismo isleño, cuando en mi primer estudio, la información oral recogida había ido en el sentido contrario (Mateu Prats 1984: 112). Por más que alguno de los que entonces me informaron, donde dijeron "digo" dicen que dijeron "diego", evitando reconocerme el haber corroborado 
documentalmente la implantación de este elemento ornamental en los usos de la payesía isleña ${ }^{91}$.

La polémica aludida, se centra, específica y nuevamente, en el tema del clauer. No se trata ya - sin embargo- de la exacta repetición de aquella otra que abarcaba al propio conjunto de cadenas, llaves y otros posibles extremos - conjunto que, como digo, y a la vista de numerosos documentos $^{92}$, parece que se ha admitido finalmente-, sino la que ha quedado como secuela, y que desde la misma perspectiva actual se enfrenta ahora al modelo indumentario que quizás habría venido siendo su más fiel compañero.

Según creo ahora entender de las explicaciones que se han argüido, parece que el cuestionar, si no el negar totalmente, la implantación social que dicho modelo indumentario pudo tener en la isla, se basa, muy fundamentalmente, en que va ceñido a la cintura. Lo que - siguiendo la argumentación formulada- estaría en contradicción con su supuesta antigüedad. Si bien no se contempla la incoherencia que parece suponer el aceptar ya la implantación social del clauer $\longrightarrow$ o tipo de joya identificado, básicamente, como "de llevar colgando de la cintura"- y el negar su asociación con un modelo estrangulado en ese punto. Resulta curioso observar que quienes opinan que, sin evolución, "las cosas se estancan y acaban muriendo", mantengan, igualmente, que la gonella, "de cuerpo pequeño, falda larga y sin cintura, el más antiguo de la Pitiuses", por lo menos se remonta a la baja Edad Media. Ante lo cual, y sin entrar en precisiones, no cabe sino recordar el grave peligro que, supone el remontar la antigüedad de un traje a épocas lejanas, sin contar con apoyos sólidos que lo justifiquen (ya sean de carácter escrito o gráfico). Sin dichos fundamentos, esta apreciación puede tan sólo formularse a nivel de hipótesis. El afirmarlo categóricamente supone un desconocimiento del retorno a hechuras de otras épocas que viene siendo característico del proceso indumentario, y por el que ciertas innovaciones temporales, evocadoras de las de otros momentos históricos, pueden ofrecer la falsa apariencia de ser rasgos definitivos, hasta llegar a convertir, de forma completamente acientífica, el conjunto en un símbolo.

Como he venido repitiendo, a principios ya del siglo XVIII, "una gonella ab Cordons" se dice en documento notarial ibicenco "a la(u)sansa de la Campaña" ${ }^{33}$. Podría tratarse, por lo tanto, de una de las gonelles

\footnotetext{
${ }^{91}$ Tras la localización de una pieza-testigo por J. Marí Tur [1973: 6 (46) - 7 (47)].

${ }^{22}$ Ver, a propósito, Mateu Prats (1996: 155-181), además de C. González de Posada 1782 en Demerson (1980: 327-334).

${ }^{93}$ API, A. Arabí, 1710-1711, f. 110 ("Antt. Tur de Thomas llaurador del qto. del pla de Vila que vivint estava per majoral al Refal de las Riveres del niculas del Pares de la
} 
(aludidas otras veces como vasquiñas, faldillas, o guardapies...), por lo regular de burell, que, como propias de la "moda forenca" o "al estilo de la tierra", son habituales en los espolits, inventarios y legados testamentarios de los labradores de la isla, y que se han identificado junto con 19, $12,9,8$, o un número indeterminado de cordones $^{94}$, "vulgo cordoneras de seda" $" 95$ en varios de estos mismos documentos dieciochescos, aunque algunos años después. Dichos cordones podrían ser así, a su vez, los que se representan como caireles o flecos cayendo desde la cintura, con impronta morisca ${ }^{96}$, en las pinturas de 1763 del púlpito de Sant Josep de sa Talaia. Del mismo modo a como cabe suponer que se apreciaría en las pinturas desaparecidas del púlpito de otra iglesia ibicenca (la de Sant Antoni de Pormany), tal como ya comenté. No ya desde la cintura, sino

Cassa de la Compañía de Jesús"). Esta ultima circunstancia trae a comentario que, precisamente, en el siglo XVIII, la afectación religiosa en cordones y hábitos, escudos, corazones, etc. "extendióse [...] a las chulas de brial corto y terciada mantilla como a las madamas de apretada cotilla y tontillo ahuecado, con sus lazos y colores [...], sin quedarse atrás las dueñas de tocas y monjiles, y en especial las devotas, con sus tocas no menos reverendas, golilla, sayo de tela, manto de anascote tendido de cabeza a pies, zapato frailesco, cordón ceñido y rosario de cuentas gordas" (Puiggarí 1890: 232-233). Si bien dicho "cordón ceñido" podría más bien reconocerse en otros registros, como el relativo a "una corretja de sañir de dona ab so cordo de seda morat", que veíamos anteriormente se ha identificado a su vez en Ibiza, aunque en este caso en el siglo XVII (API, Bermeu, 1634-1640). Por otro lado, los paralelismos entre la indumentaria de los religiosos y la de los seglares quedan demostrados en alguna ocasión a través de la propia nomenclatura de las prendas, como por ejemplo se ha atestiguado en la misma Ibiza con un "Gupitin [...] a la capuchina" (API, J. Sala, ff. 43v-44), pues se llamaba así la chupa de tela rica "cuyas espaldas y mitad de las mangas" eran de lienzo, o de otra tela ligera, por alusión a los remiendos de los Padres Capuchinos, que eran de otro color del sayal, según consta en el Diccionario de Autoridades.

${ }^{94}$ API, J. Sala, 1763, ff. 79v, 133v,169v y 189.

${ }^{95}$ API, M. Rosell, 1767, f. 3: "Una gonella de burell noua ab sa cordonada de seda noua" ("llaurador del Quarto de Santa Eularia y lloch de la Britga"); API, R. Oliver y Castelló, 1786, f. 19: "Quatro Basquiñas de Embuit todas con su Cordonera"; Ibidem, f. 96v: "una Basquiña de Borel, con sus Cordoneras"; Ibidem, f. 131: "dos Basquiñas de Borel, una nueva con sus cordoneras y la otra usada". Sin que conste su relación con las gonelles, u otras prendas: API, J. Sala, 1747, f. 40v: "treinta y nueve cordoneras de seda tales quales"; API, M. Rosell, 1767, f.. 75: "tres dotsenas de Cordoneras de seda de Valencia" ("Barthomeu Castello de Miguel gorch del Quarto del Pla de Vila habitant en lo Arraval de la Marina").

${ }^{96}$ Por estos mismos años se ha reconocido el registro de varias "precintas moriscas": API, Arabí, 1708-1710, f. 91v: "una Persinta Morisca" ("qto de Sta. Olaria y lloch de obarqueta"); API, J. Sala, 1763, f. 102v: "una Persinta morisca buena" (anteriormente citados dos capuchos largos y una alfombra morisca pequeña, y más adelante un capotillo "capuchet corto"); API, R. Oliver y Castelló, 1786, f. 197v: "una persinta morisca". 
más ligera o acusadamente hacia arriba, con el consiguiente acortamiento del busto a favor del alargamiento del faldar, vemos pender dichos cordones o flecos en "el traje de clauer" captado en una antigua postal, así como en las fotografías realizadas por la Escuela Madrileña de Cerámica y por Ortiz Echagüe, en 1933 (Láms. 15, 16 y 17). La modificación que se advierte a través de ese desplazamiento hacia arriba de la línea de cintura, podría así deberse, tal como vengo insistiendo para la gonella negra, a la repercusión en la payesía de la moda imperio en la propia gonella de clauer, que quedaría, de esta forma, finalmente, fosilizada.

$\mathrm{Y}$ este acortamiento del busto es otro de los datos que tampoco se ha tenido en cuenta a la hora de polemizar sobre la representatividad o no en el vestir antiguo de Ibiza de dicha variante. Si el argumento fundamental en que parece querer apoyarse esa negación es que este modelo no muestra uno de los rasgos que hoy se consideran característicos de la indumentaria femenina tradicional, estos últimos testimonios gráficos vienen a demostrar todo lo contrario. Esta diferenciación, transformación o evolución, sobre una gonella que se considera habría cerrado su ciclo años atrás, viene a plantear, en cambio, otras preguntas: ¿La indumentaria de las figuras femeninas en el púlpito de Sant Antoni difería, en este punto, de la que aparece en el de Sant Josep??7 ¿Estamos, acaso, ante el traje de clauer en sus últimos momentos de vigencia social? ¿Cuándo podemos decir, realmente, que desapareció el "traje de clauer"? Lo que sí parecen venir a demostrar todos estos testimonios gráficos es que los ibicencos de entonces aún lo reconocían como propio, esto es, como representativo, cuando menos, de su pasado tradicional. Incluso podríamos pensar que todavía no habían roto con el "cordón umbilical" o sentimental que les unía él, de la misma forma que los ibicencos y formenterenses actuales aún lo mantienen con el traje de la gonella negra... El problema que esto plantea no sería ya, pues, el de su presencia o implantación en un pasado, sino determinar cuándo habría dejado de tener vigencia social. Admitiendo la suposición de que este modelo, en la que sería su última fase, hubiese modificado ligeramente la hechura por la repetida influencia de la moda imperio, desplazando hacia arriba

${ }^{97}$ Como ya recogía en anteriores estudios, la documentación notarial ofrece muestra en 1763 de un "cosete de Borel de muchachas buenas" (API, J. Sala 1763, f. 103), para cuya consideración sería fundamental su realización en dicho tejido (Mateu Prats 1996: 178), teniendo en cuenta que la humildad del mismo armonizaba con la honestidad de las "bien casadas", de las viudas, e incluso, por qué no, de las al.lotes casaderas (Véase a propósito la nota 60 de dicha publicación). Dejando abierta la posibilidad de que tal consideración pudiera obedecer a alguna característica de hechura de esta prenda de busto. 


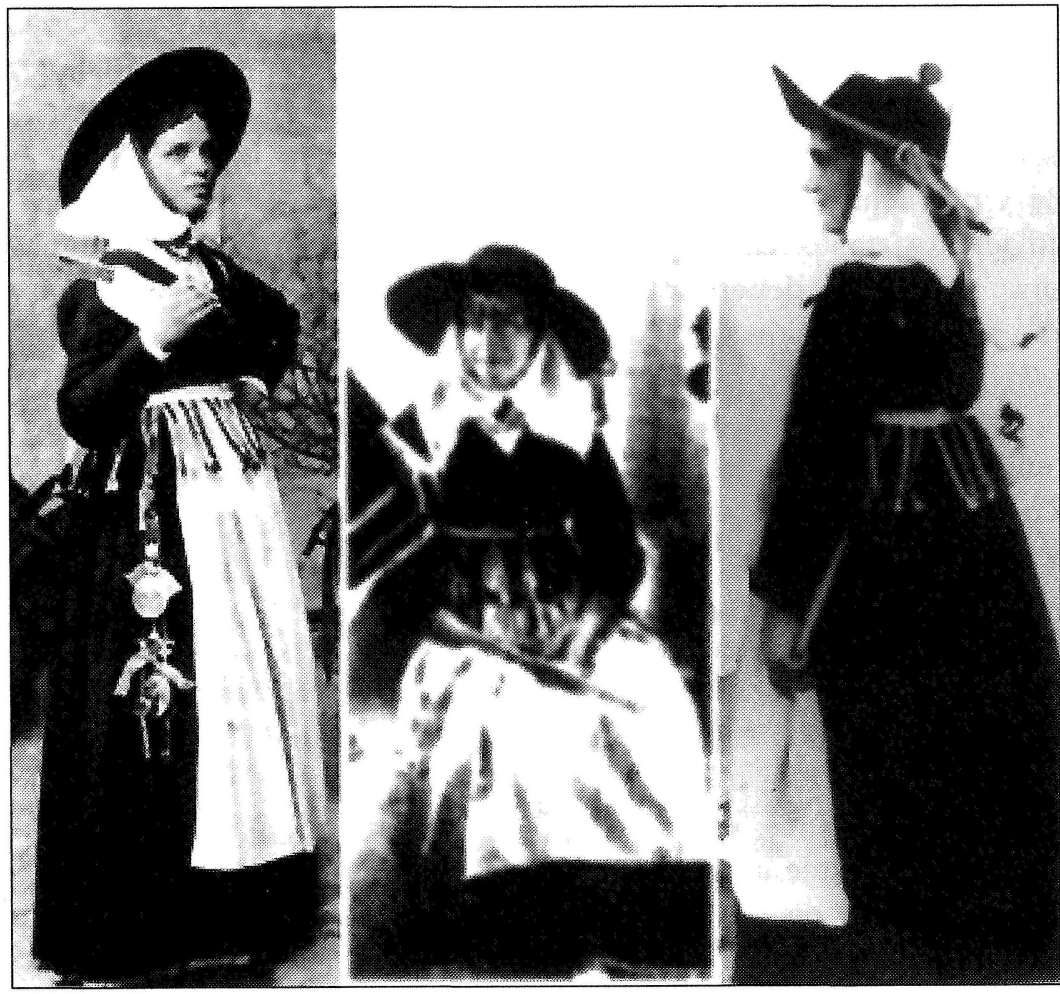

FIGURAS 15, 16 y 17.-Fragmentos de una antigua postal y de las fotografias de la Escuela Madrileña de Cerámica y de Ortiz Echagüe.

la línea del talle, dicha transformación, o evolución, sí podría haber resultado fundamental:

- Por un lado, habría podido acabar rompiendo la vinculación de este traje con el clauer, al ser éste, como indicábamos, un tipo de joya especialmente de llevar colgando de la cintura.

- Por otra parte, la admisión generalizada del mantón en la payesía durante el siglo XIX, a que ya nos estamos refiriendo, haría innecesaria la presencia de "cordoneras" en la cintura. Teniendo también en cuenta, que, cuando hablamos del burel, estamos aludiendo a un tejido burdo, análogo al que ha venido configurando a la gonella negra ${ }^{98}$; en realidad estaríamos ya ante un modelo prácticamente idéntico al de la referida gonella que hoy conocemos, con la salvedad de la condición plisada de ésta última.

En lo que respecta al propio clauer, no sé hasta qué punto podría servirnos de orientación para su paulatina desaparición en el costumbrismo

${ }_{98}$ Aunque la documentación distinga entre uno y otro tejido. 
ibicenco, el que, según se ha escrito, los colgantes similares que se sujetaban a la cinta de la mujer con una placa en forma de gancho, hubiesen pasado de moda hacia 1830, si bien se mantuvieran por más tiempo con carácter utilitario (Montañés y Barrera 1987: 268). No olvidemos, tampoco, el mayor arraigo de las modas que suele darse en los estratos populares. Aunque en sentido en cierto modo contrario, no debamos tampoco pasar por alto un hecho habitual y, por lo tanto característico, que afecta muy especialmente a dichas capas de la sociedad: la frecuente necesidad, ante circunstancias económicas desfavorables, de tener que desprenderse de las piezas de valor. Motivo que incide, muy negativamente, en la conservación de joyas o piezas-testigo.

Acerca de los datos que sobre "el adiós" del claner aporta la documentación notarial, y sin podernos pronunciar todavía al respecto, un sondeo previo parece insinuar que éste podría haberse ido produciendo ya en el primer cuarto del XIX ${ }^{99}$. Dato provisional que debemos tomar con extrema prudencia, considerando, además, que todavía a finales del siglo XVIII el clauer se citaba como propio de las campesinas ibicencas, tal como recogíamos al recordar el testimonio de C. González de Posada, $\mathrm{y}$ tal como vienen a corroborar numerosos documentos ${ }^{100}$.

A favor, en todo caso, del sentimiento de pertenencia, como de "algo propio", a que también antes me refería, y que todavía podía inspirar el "traje de clauer" a los ibicencos, bien entrado el siglo XX, son todos aquellos testimonios que nos han llegado sobre su intento de recuperación. Aparte, claro está, del criterio intelectual, o histórico, que pueda traslucir, tal como en este caso insistió Toni Manonelles en su conferencia pronunciada en las II Jornades de Cultura Popular a les Pitiuses (Manonelles 2003). Bajo ambos y complementarios enfoques creo que resulta oportuno detenernos, por última vez, en ello.

\section{Recuperación del traje de clauer}

Ateniéndonos a lo manifestado por Ortiz Echagüe (1971: 20), que se desplazó a Ibiza en 1933, las pinturas por entonces aún existentes en el púlpito de la iglesia Sant Antoni habían servido de modelo para la répli-

99 API, V. Gotarredona, 1816, f. 151v: "un llavero con joyas de plata" ("Quarton de Santa Eulalia"); ibid., f. 167 "un llavero con quatro agnus y una joya [...] pequeña".

${ }^{100}$ Ejs: API, R. Oliver y Castelló, 1786, f. 248: "un Llavero con cinco llaves y una joia tambien de plata"; API, V. Gotarredona, 1797, f. 38v: "Un Llavero con tres agnus de plata", junto con una "sinta u cadena de plata", "Quarton de Pormany"... 
ca del traje en cuestión, en un intento por recuperar lo que se consideraría un legado propio de la cultura material. "En el pequeño pueblo de San Antonio, en el púlpito de su iglesia —escribió a propósito-, hay figuras plasmadas que han servido de guía para la confección de estos trajes del antiguo campesino de Ibiza"101. Comentario que, como asimismo indicaba, plantea la duda de si las mujeres alli pintadas mostraban un acortamiento del busto, tal como muestra la reproducción del traje captada por el mismo Ortiz Echagüe.

Recordemos también que de dicho púlpito, ya a finales del siglo XIX, se había escrito que un pasaje del pedestal mostraba una "curiosa prueba" de los trajes usados en $1769^{102}$. La pérdida de estas pinturas - tal como igualmente he venido repitiendo- queda en cierto modo paliada, gracias a la existencia de otras similares en una de las tablas del púlpito de Sant Josep de sa Talaia, pintadas en 1763 por José Sánchez de Ocaña ${ }^{103}$.

En el mismo año que Ortiz Echagüe vino a Ibiza, también lo hicieron los miembros de la Escuela Madrileña de Cerámica de la Moncloa, con el principal objetivo de captar en sus acuarelas la indumentaria tradicional de la isla, dado su gran interés; acuarelas realizadas en la villa de Santa Eulalia, y en las que, entre los otros trajes, quedó plasmada la gonella llamada de clauer.

Fui precisamente yo quien, en Madrid, localizó esas acuarelas de temática ibicenca, así como varias fotografías, antes de entrevistar a algunos de esos pintores y de redactar el guión para el vídeo correspondiente, realizado en 1991 por Joseph María Bassols. Hablo pues, también en este caso, de un tema con el que, en cierta manera, mantengo una especial relación. De lo que pudo suponer en la isla la llegada de estos artistas, al efecto de lo que ahora estamos tratando, ya señalé hace años un hecho aparentemente superfluo, pero en el que, por el contrario, cabe vislumbrar una gran trascendencia: "Nos referimos — decía- al hecho en sí de ataviarse unos ibicencos con tales prendas al efecto de posar ante unos fotógrafos y pintores que se habían fijado entre sus metas la salvaguarda de la indumentaria tradicional" (Mateu Prats 1997: 6). "Si bien este argumento - proseguía-, tomado al pie de la letra, es susceptible de

101 "En el citado púlpito - proseguía-, las mujeres aparecen con sus trenzas encintadas, las que penden en lugar de formar rodete o aureola como en Ansó” (ibid.).

102 Pablo Piferrer y J. M. Quadrado (1888: 1380). Al reseñar el púlpito de la iglesia de San Antonio se decía lo siguiente: "...la representación de los misterios de dolor en la barandilla del púlpito por inexperto pincel, que en otro pasaje del pedestal, mostrándonos al párroco en actitud de enseñar el catecismo a sus feligreses, dejó curiosa prueba de los trajes usados en aquella fecha de 1769".

103 J. Marí Cardona (1990: 104-105). 
poder rebatirse, aludiendo, quizás, la general corta edad de esos modelos, debe aclararse que con ello indicamos la responsabilidad ibicenca en la elección de esos trajes. Una responsabilidad que recaería en personas idóneamente cualificadas, teniendo en cuenta, por ejemplo y ya en principio, la entidad intelectual de la propia Escuela de Cerámica, así como la del que fue uno de sus anfitriones en la isla: D. Manuel Sorá" (ibid.).

En lo que respecta a la antigua postal, o tercer testimonio gráfico del "traje de clauer" al que aludía anteriormente, la hallamos reproducida como dibujo en el estudio de Amades sobre el "vestido pitiúsico", donde se dice lo siguiente: "Hace unos años que Pedro Marí, funcionario del Museo Arqueológico de Ibiza, muy conocedor de las costumbres y tradiciones de la isla, investigó y reunió los vestidos antiguos más característicos, a fin de poder estampar unas postales de indumentaria típica ibicenca, de las cuales hemos podido sacar algún detalle" (Amades 1969: 96). Por consiguiente, parece lógico interpretar que la postal señalada fuese una de las realizadas tras la labor de investigación y recopilación llevada a cabo por el mencionado Pedro Marí sobre los trajes antiguos y más característicos - subrayo estas dos consideraciones- de la indumentaria típica ibicenca. A este propósito cabe a su vez recordar lo que yo misma escribía en el referido artículo (Mateu Prat 1997: 6). "Entre todos estos

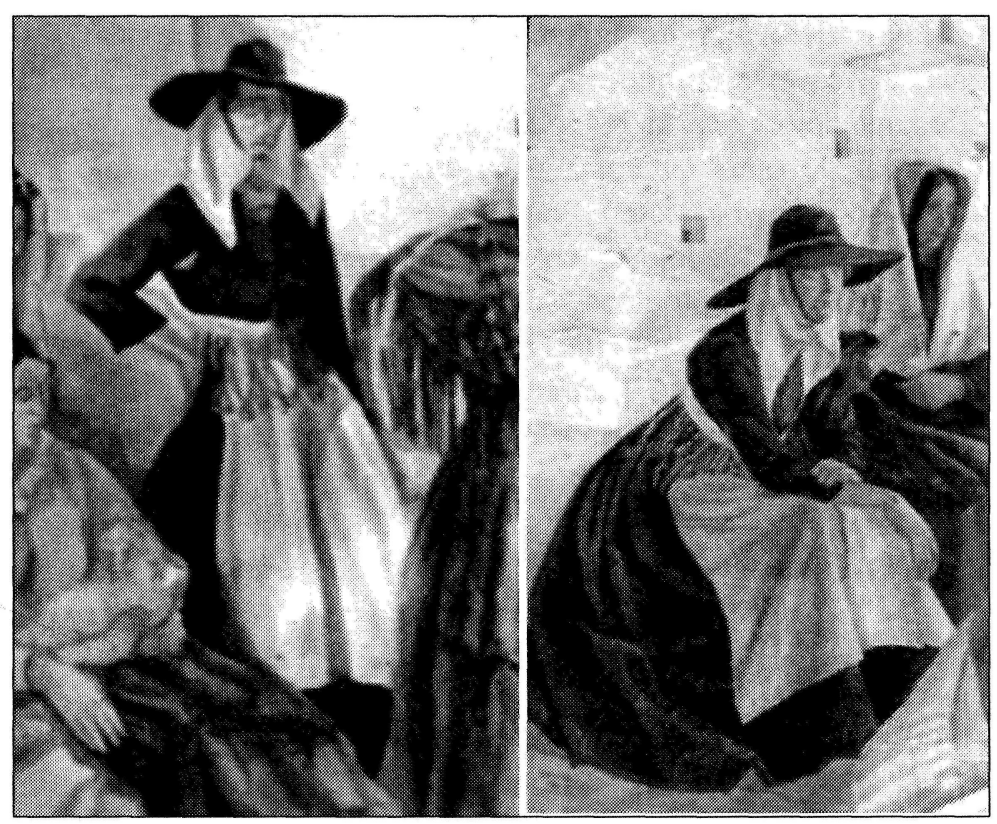

Figuras 18 y 19.-Detalles de la acuarelas núms. 1921 y 2073 de la Escuela Madrileña de Cerámica; Santa Eulalia, 1933. 
intentos por recuperar - al menos para la memoria colectiva- esos "antiguos trajes de los campesinos de Ibiza" (siguiendo nuevamente las palabras de Ortiz Echagüe), nos satisface a nivel personal poder citar el protagonizado por una de mis bisabuelas por línea materna: ibicenca nacida en el año 1860"104 (aproximadamente) "y de muy hondas raíces isleñas". "Fue en los últimos años de su vida cuando mostró la clara intención de vestir a una de sus nietas con el "traje de clauer", movida por el deseo de que ese atuendo figurara entre los modelos indumentarios de la isla, en la filmación que NO-DO estaba realizando con este propósito en la isla, allá por el año de 1942 o 43"105.

"Dejando aparte - proseguía - que este proyecto familiar no se llevara a cabo (y que la nieta en cuestión apareciera finalmente en el citado Documental luciendo la gonella negra y emprendada de plata y coral), dicha circunstancia resulta hoy de por sí suficientemente significativa, pues no sólo nos permite acceder a la identidad de una de las personas involucradas en esta "reivindicación" del traje de clauer, sino que además podemos adentrarnos en la personalidad de esta ya por entonces octogenaria ibicenca de la Marina (Doña Isabel Escandell Ferrer), y a quien aún se recuerda - entre otras características- por su gran conocimiento del costumbrismo isleño". De la vigencia que se reconoce a este traje en el pasado de Ibiza, es un ejemplo el estudio Temps ha... Indumentaria de les Pitiuses ${ }^{106}$, realizado en conjunto por J. Marí Tur y el pintor Antonio Pomar.

En la ilustración —que recoge el testimonio de la oportuna antigua fotografía, aludida anteriormente (fig. 20)—, puede advertirse la referida modificación o evolución morfológica en ese modelo indumentario, por más que no haya podido comprobar, para esos momentos tan tardíos, una continuidad en su uso. Dicha modificación o evolución, que precisamente afecta al desplazamiento hacia arriba de la línea de cintura, así como a la adopción de un cuerpo con mangas (para el que se ha remitido al gipó llevado en Formentera) ${ }^{107}$, vuelve a corroborarse fotográfica y

104 Según la fecha aportada por algunos de mis familiares.

105 Igualmente según los datos aportados por la propia familia.

106 J. Marí Tur (textos) i A. Pomar Juan (dibuixos) (1989: 34-35): "Aquest vestit - se escribe a propósito- el podem veure a sa trona de s'esglesia de Sant Josep i es podia contemplar a sa de Sant Antoni. [...] Crida s'atenció es cinturó d'on pengen cintes de colors i, sobretot, es clauer; un rest de claus i joies de plata dels quals només en tenim un i encara per casualitat".

107 "Reparem amb so gipó i comparem-lo amb es que porten a Formentera" (Marí Tur y Pomar 1989: 34). 
pictóricamente, insisto en los testimonios recogidos por los miembros de la Escuela Madrileña de Cerámica, en 1933.

El cuestionar o prácticamente negar, sin contar con argumentos que realmente lo justifiquen, el posible uso de unos $\mathrm{u}$ otros modelos en el pasado, o el de algunos de sus rasgos tipológicos, por el simple hecho de que éstos no se adaptan a la imagen que hoy tenemos de la indumentaria popular, no sólo puede llevar a falsear el proceso evolutivo del traje, sino también a ignorar el contexto histórico y social en que ese tuvo lugar, dejando ahora aparte la propia evolución que cabe reconocer en el traje de forma individualizada, en función del ciclo vital, con la consiguiente diferenciación de circunstancias, como estado y edad, posición social, gustos, etc.

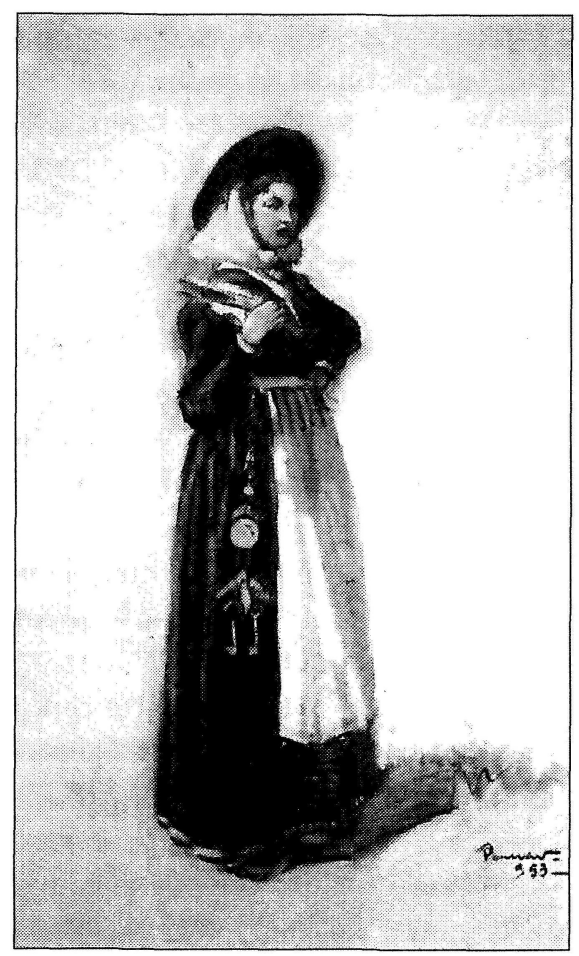

FIgURA 20.-Vestit de clauera (Pomar).

\section{RESUMEN VALORATIVO Y APRECIACIONES FINALES}

Más que conclusiones definitivas, mi intención aquí ha sido la de sopesar, de la manera más objetiva posible, los "pros" y los "contras" que apoyan o dificultan una u otra interpretación, no ya a la hora de intentar determinar la mayor o menor antigüedad de unas prendas u otras, sino a la de entender los propios parámetros en que se enmarca la manifestación indumentaria.

Centrándonos en la de carácter tradicional, de los trajes que en el Estado español vienen considerándose representativos de unas regiones $u$ otras, se ha señalado que constituyen el muestrario más rico y variado de Europa, tanto en función de razones naturales como históricas; es decir, gracias a los fuertes contrastes geográficos y climáticos existentes, así como a motivaciones económicas, políticas y religiosas. Se ha dicho también que proceden de modas de finales del siglo XVIII o burguesas del XIX, fijadas y estabilizadas desde 1750 a 1880 (Ministerio Cultura 1991: 58). 
Muchos de los modelos indumentarios femeninos, con su división en prendas de busto y cintura, se corresponden con el siglo XVIII. Lo que no impide que algún otro, igualmente ceñido en el talle, ya hubiera quedado fosilizado en el siglo XVII (el traje de boda de la Sierra de Francia y Candelario). De las basquiñas o gonellas de Ansó e Ibiza, los investigadores consultados, tanto suelen limitarse a señalar que constituyen un capítulo aparte, como a aludir una posible pervivencia medieval para las primeras, aunque dicha posilidad se apoye básicamente en el tocado, en lugar de en la hechura recta que igualmente la viene caracterizando. En este sentido, a la hora de intentar aproximarnos al pasado de la indumentaria popular portada por las mujeres de Ibiza a través del recorrido iconográfico, todas las fuentes comentadas de los siglos XVIII y XIX coinciden en mostrar un estrangulamiento en la cintura, tal como a su vez apuntan numerosos registros de gipons y las reseñas de A. Flores y del propio Archiduque Luis Salvador.

El salto que, desde los testimonios iconográficos más antiguos, podemos realizar hacia otros semejantes y aún más alejados de nosotros en el tiempo, ya me llevó hace unos años (Mateu Prats 1996: 159) a reconocer en el retablo de San Esteban del Taller de los Vergós conservado en el Museo de Cataluña un significativo paralelo. Estoy hablando nuevamente de la mujer del siglo XV plasmada con toca, gonella y clauer, que a su vez se muestra ceñida en el talle. Mujer que, cabe suponer, no diferiría ostensiblemente de las "mugeres" con toca, dueñas, casadas o, de edad, que, según Puiggarí (1890: 46, 95), y ya en el siglo XIII, portaban las llaves colgando del cinto, por lo regular delgado, de correa, paño o terciopelo; es decir, similares al que muestra esa figura del siglo XV. Todo lo cual me permitía retroceder en el estudio de estos usos hasta el siglo $\mathrm{XIII}^{108}$. Por el contrario, si intentamos buscar una explicación para la diferenciación existente en la hechura de esas representaciones de saya acampanada con estrangulamiento en el talle y la gonella negra, de aspecto tubular, captada por el Archiduque Luis Salvador unos años después, resulta quizás ilustrativo observar cómo por entonces ya se había

108 "El clauer portado tradicionalmente por las ibicencas es un ejemplo de las joyas que se llevaban colgando desde la cintura. Los Protocolos isleños reflejan la configuración de dicho clauer, y el papel que desempeñaban en los derechos consuetudinarios de dote y herencia". A lo que se añade "su especial relación con la boda, sus connotaciones sociales y simbólicas y su íntima conexión con la indumentaria". Tras lo cual concluía que "a los paralelismos detectados en el archipiélago", se sumaban aquellos otros que ilustran sobre la generalización de este elemento y su antigüedad, que, en el estado actual de la investigación, es posible retrotraer hasta la señalada centuria (ibid:: 181). 
producido un retorno a hechuras características de otras épocas, dentro del proceso de la evolución indumentaria. De hecho desde 1789 en aquellos lugares y contextos sociales en sincronía con los vaivenes de la moda, la inspiración greco-latina del estilo imperio había conducido al uso de vestidos largos, con corte bajo el pecho y falda fruncida y recta (Ministerio de Cultura 1991: 188). Es decir, tal como prácticamente viene siendo característico de la gonella que hoy conocemos, y tal como ya se refleja -al menos en lo que concierne al aspecto tubular y propios complementos- en la aludida mujer con traje típico reproducida por el Archiduque Luis Salvador (Figura. 21), si bien éste pareciera todavía referirse a cuerpos ceñidos y a gonelles o faldas desde la cintura. En todo caso, la ilustración del Archiduque Luis Salvador nos hace recordar la observación que A. Mulet hiciera sobre la evolución seguida en nuestro propio archipiélago, cuando comentaba las doce láminas de Juan de la Cruz. En su opinión, si aún por entonces estaba vigente la riqueza del Barroco, ya comenzaba a apreciarse la tendencia "a una espiritualización que había de estilizar grandemente el gusto imperio" (Mulet 1951: 4). Tras lo cual, y centrando su estudio en la indumentaria femenina en Ibiza, continuaba arguyendo, y de modo concluyente, que "conservada la gonella durante el XIX hasta nuestros días, la moda imperio dio además a la ibicenca nuevas galas, que no oscurecieron las anteriores..." (ibid.: 14).

Desde esta perspectiva, y admitiendo que los trajes que hoy se conocen como representativos de unas regiones $u$ otras en realidad proceden de modas de finales del siglo XVIII o burguesas del XIX, fijadas y estabilizadas desde 1750 a 1880 (Ministerio de Cultura 1991: 58), podría situar cronológicamente la referida transformación en el período apuntado, sin olvidar la ralentización y adaptación a tejidos humildes, propia de los estratos populares. A ello me refería en otra publicación cuando aludía a los trajes de carácter tradicional que en el siglo XIX tuvieron que enfrentarse con las "frívolas modas europeas". Los mismos, decía, que "pese a haberse quizás dejado seducir por ellas, y de haber ido perdiendo su vida o vigencia social, en ese momento, ganaron una equívoca victoria: la de alzarse como símbolo o seña de la identidad isleña" (Mateu Prats 2003: $135-136)^{110}$.

${ }^{109}$ Lámina en color litografiada sobre el traje típico femenino, según dibujo original del autor y realizada bajo su dirección por el pintor Emil Lauffer. (Archiduque Luis Salvador, cito por ed. de 1982: 37).

${ }^{110}$ Siguiendo este planteamiento, la silueta triangular, o más voluminosa, que viene caracterizando a las gonelles blancas o de color, podría ser, por su parte, un claro reflejo de la época romántica 


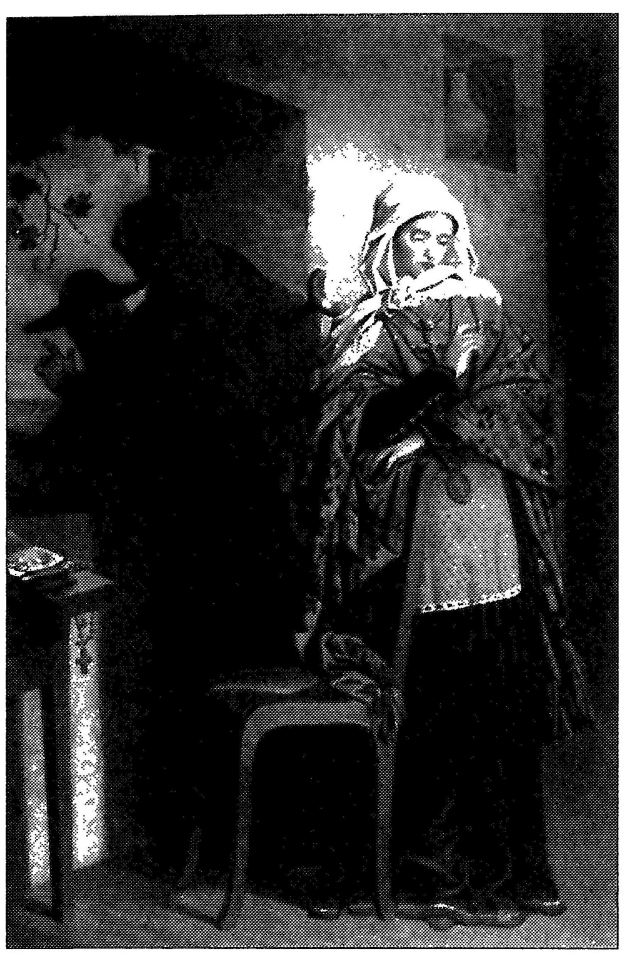

FIGIJRA 21.-Mujer con gonella negra (Archiduque Luis Salvador) ${ }^{10 \%}$.

Por otro lado, y ya para concluir, puedo decir que ha sido también mi intención al aproximarnos a la evolución de las gonelles en Ibiza a través de la documentación escrita y gráfica, demostrar lo sumamente complejo y difícil que resulta el estudio etnohistórico de la inclumentaria, tal como recientemente ha observado B. Escandell (Escandell Bonet 2001: 620$621)^{111}$, quien por este motivo justifica que sean sumamente escasos los estudios sobre esta materia. Valiéndome en cierta medicla de la comparación que se ha aducido para casos semejantes, diría que cada cita notarial o bibliográfica y detalle iconográfico, así como cualquier dato recogido en trabajo de campo, pasa a formar parte de una tesela o pieza de mosaico, que a su vez hay que ensartar con otras muchas para obtener una visión global. La labor del estudioso no es otra que intentar recomponer ese mosaico que el paso del tiempo ha ido deteriorando, comenzando por aquellos tramos más fáciles de recomponer, e ir luego colocando las piezas que esperan su oportuna ubicación, según nos vaya guiando la propia reconstrucción.

\section{BIBLIOGRAFÍA CITADA}

Alcover, A. y F. Mol... 1988. Diccionari Català, Valencià, Balear (Inventari lexicogràfic de la llengua calalana en totes les seves formes literàries $i$ dialectals, recollides dels documents $i$ textos antics $i$ moderns, $i$ del parlar vivent al Principat de Catalunya, al Regne de Valencia. a les Illes Balears, al departament francès dels Pirineus orientals, als Valls d'Andorra al marge oriental diragó $i$ a la ciutat d'Alguer de Sardenya). Obra iniciada por Mn. Antoni Alcover i Francesc de B. Moll

111 Véase nota 59 de este mismo artículo. 
Alfau DE Solalinde, M. J. 1969. Nomenclatura de los tejidos españoles del siglo XIII. Madrid: Anejos del Boletín de la Real Academia Española. Anejo XIX.

AMADES, J. 1969. Folklore de Cataluña. Costumbres. Barcelona.

BELtRÁn, A. 1991. "Aspecto económico y uso diario en el traje", en Moda en sombras: 27-32. Madrid: Ministerio de Cultura.

Bernis Madrazo, C. 1957. "Indumentaria española en el siglo XV". Archivo Español de Arte XXX: 187-209.

- 1959. "Modas moriscas en la sociedad cristiana española del siglo XV y principios del XVI". Boletín de la Real Academia Española CXLIV.

- 1962. La indumentaria española en tiempos de Carlos V. Madrid: CSIC.

- 1979. Trajes y modas en la España de los Reyes Católicos II. Madrid: CSIC.

Caño y Olmedilla, J. de la C. 1771. Colección de trajes de España tanto antiguos como modernos que comprende todos los de sus Dominios, Dividida en dos Volúmenes con ocho quadernos de doze estampas cada uno. Dispuesta y grabada por D. Juan de la Cruz Cano y Holmedilla. Se hallará en Madrid, Casa de M. Copín.

CARo Baroja, J. 1986. "Prólogo", en Tipos y Trajes de Zamora, Salamanca y León. Acuarelas de la Escuela Madrileña de Cerámica. Zamora: Caja Zamora.

CASAdo Lobato, C. 1991. "Indumentaria tradicional", en Moda en Sombras: 11-15. Madrid: Ministerio de Cultura.

CEA GutiÉrRez, A. 1983. "El traje de los alrededores de Salamanca como lo vieron los grabadores de los siglos XVIII y XIX". Revista de Folklore 36: 183-194.

- 1985. Guía de la Artesanía de Salamanca. Madrid: Ministerio de Industria y Energía.

- 1986. "Salamanca", en Tipos y Trajes de Zamora, Salamanca y León. Acuarelas de la Escuela Madrileña de Cerámica: Zamora: Caja de Zamora.

- 1991a ."Los trajes en España, códigos apasionantes". Pabellón de España -10: 10-14.

- 1991b. "Las joyas, una geografía de la personalidad". Pabellón de España -7: 22-27.

- 2000. "Prólogo", en M. L. Mateu Prats, El mon devocional.a Eivissa. Retaules e imatges del col.leccionisme privat (s. XVII-XIX): 13-16. Eivissa: Ed. Mediterrania.

- 2002a. "Conocer la sociedad a través de la indumentaria". Diario de Ibiza 9 de mayo, portada y 11 .

- 2002b. "La indumentaria en el refranero de Correas. Retrato y Caricatura de la España del siglo XVII", en Moda y sociedad. La indumentaria: estética y poder: 101-136. Granada: Universidad de Granada.

- 2003. - Supuestos generales para el estudio de la indumentaria", en II Jornades de Cultura Popular a les Pitiüses. Es vestir antic: 15-42. Eivissa: Federació de colles de ball i cultura popular d'Eivissa i Formentera.

Colomar, A. 2002. "Catálogo", en Les Pitiüses en gravats. Segle XIX. La imatge de les Pitiüses en la il.lustració grafica. Eivisssa: Arxiu Historic d'Eivissa. Eivissa.

Covarrubias, S. 1984 [1610]. Tesoro de la Lengua Castellana o Española. Madrid-México: Turner.

Demerson, J. 1989. Ibiza y su primer obispo D. Manuel Abad y Lasierra. Madrid: Fundación Universitaria Española.

Demerson, J. y P. 1993. Sexo, amor y matrimonio en Ibiza durante el reinado de Carlos III. Palma de Mallorca: Ed. El Tall.

ESCANDELL BONET, B. 1994. "Las fuentes archivísticas", en Ibiza y Formentera en la Corona de Aragón (Siglos XIII-XVIII) I: 82-83. Palma de Mallorca: Ed. El Tall.

- 2001. "Influencias indumentarias: 'en la Villa visten a la española", en Ibiza y Formentera en la Corona de Aragón, Tomo III/1. De la crisis barroca a la planifi- 
cación ilustrada. Siglo XVII: 620-621. Oviedo: Servicio de Publicaciones de la Universidad de Oviedo.

FAJARNÉS CARDONA, E. 1995. "Campesinas ibicencas ante Isabel II", en Lo que Ibiza me inspiró. Ibiza: Ibosim, 3." ed.

FAjarnés Tur, E. 1930. Política económica de Ibiza en el siglo XVII. Palma: Colomar.

FERRER JUAN, N. 2002. "La imatge de les Pitiüses en la il.lustració grafica del segle XIX" en Les Pitiüses en gravats. Segle XIX. Eivissa: Arxiu Historic d'Eivissa.

GISCARD, P. H. 1822. Delineations of the most remarkable costumes of the diferent Spain provinces of Spain, and also of the military uniforms, bull fights, national dances $\varepsilon$ s. Of the Spaniards. Londres: Publisch by Henry Stokes.

GONZÁLEZ DE POSADA, C. 1980 [1782]. "Adiciones a las noticias sobre Ibiza y Formentera de D. Manuel Abad y Lasierra" publicadas en Ibiza arqueológica e bistórica en 1791, en Ibiza y su primer obispo Abad y Lasierrra: 327-334. Madrid: Fundación Universitaria Española. También en las II Jornades de Cultura de les Pitiüses. Eivissa: Can Imprés.

HERnÁNDEZ SANZ, F. 1908. Compendio de geografía e historia de la isla de Menorca. Mahón.

HOYOS SANCHO, N. de 1935. "Tocados y peinados femeninos regionales en España". Anales del Museo del Pueblo Español I (1): 175-186.

- 1944-1945. "Folklore indumental en España". RDTP I: 139-157.

LEIRA SÁNCHEZ, A. 1991. "El traje en el reinado de Carlos III", en Moda en Sombras: 16-20. Madrid: Ministerio de Cultura.

LOZOYA, MARQuÉS DE. 1975. Historia de España. III. Barcelona: Salvat.

LuIS SALVADOR, ARChIDUQUE. 1869-1891. Die Balearen in Wort und Bild geschildert. Leipzig: F. H. Brockhaus, 1869-1891, 9 vols.; Die Balearen. Geschildert in Wort und Bild. Würzburg und Leipzig: K.U.K. Hofbuchhandlung von Leo Woerl, ed de 1897, 2 vols.; Las Balears. Obra escrita y publicada en alemán con el título de Die Balearen in Wort und Bild Geschildert. Versión castellana de D. Santiago Palacio Vice-Cónsul de España en Berlín. Corregida y considerablemente aumentada con anuencia y conforme a las indicaciones del autor por D. Francisco Manuel de los Herreros y Shwagr, Director del Instituto Balear. Palma de Mallorca: Imprenta de la Biblioteca Popular, 1886 (vol. I) e Imprenta del Comercio, 1890 (vol. II). Cito por Las Baleares por la palabra y el grabado. Primera Parte. Las Antiguas Pitiusas, ed. de 1982 de la Caixa de Balears "Sa Nostra", traducción de Carlos y Bárbara Sánchez Rodrigo, coordinación de Isabel Moll Blanes.

MACABICH, I. 1966-67. Historia de Ibiza. Ibiza: Daedalus, 4 vols.

MANONElles, A. 2002. "Ball pages al segle XXI", en Abir Avui. Ball pagès. I Jornades de Cultura popular de las Pitiüses: 45-61. Eivissa: Can Imprès.

- 2003. "La indumentaria tradicional als grups folklòrics", en II Jornades de Cultura Popular a les Pitiüses. Es vestir antic: 63-77. Eivissa: Federació de colles de ball i cultura popular d'Eivissa i Formentera.

Marí Cardona, J. 1985. Sant Antoni de Portmany. Eivissa: Institut d'Estudis Eivissencs.

- 1990. Illes Pitiüses VI. Portmany. Eivissa: Institut d'Estudis Eivissencs.

Marí TUR, J. 1973. "El clauer i l'adrec, dues peces de l'orfebreria popular eivissenca". Eivissa núm. 2 de la 3. ${ }^{a}$ época:

Marí Tur, J. (textos) y A. Pomar (dibuixos). 1989. Temps ha... Eivissa: Caixa de Balears "Sa Nostra".

Mateu PRATS, M. L. 1984. La joyería ibicenca. Palma de Mallorca: Institut d'Estudis Baleàrics. 
- 1985a. Joyería popular en Zamora. Zamora: Caja de Ahorros Provincial de Zamora.

- 1985b. "Aspectes arqueologics i etnologics de la joieria popular d'Eivissa". Eivissa 1516, 3. época: 38-44.

- 1985c. "Arracadas con colgantes en forma de vaina de guisante. Notas relativas a su posible origen y simbolismo", en Anuario 1984: 15-21. Zamora: Instituto de Estudios Zamoranos Florián de Ocampo.

- 1985d. "Joyería popular en Zamora". Oro y Hora 313: 10-15.

- 1985e. "Símbolos mágico-sexuales en la antigua joyería ibicenca". Estudis Baleàrics: 71-89.

- 1986. "Simientes representadas en la joyería popular de Zamora", en Anuario 1985: 237-261. Zamora: Instituto de Estudios Zamoranos Florián de Ocampo.

- 1989. "Joyería popular ibicenca. Una selección de treinta siglos". Joyas \& Joyeros 40: $30-33$.

- 1991. "El traje en Ibiza durante el siglo XVIII: Variantes de la Gonella de burell y los calçons de negrilla", en Actas de la Conferencia Internacional de Colecciones y Museos de Indumentaria: 229-236. Madrid: Ministerio de Cultura.

- 1993. "La gonella de burell i clauer al llarg dels segles XVII i XVIII". Eivissa 24: 26-32.

- 1996. "El clauer en Ibiza a partir de la documentación del siglo XVII". RDTP LI (2): $151-181$

- 1997. "El traje de clauer un código apasionante". El Dominical del Diario de Ibi$z a$. 6 de octubre: 12-16.

- 2000. El món devocional a Eivissa. Retaules $i$ imatges del col.leccionisme privat (s. $X V I I-X I X)$. Eivissa: Ed. Mediterrania.

- 2003. "Robes a la morisca a l'Eivissa d'ahir. L'especial impacte d'aquest corrent en el mon tradicional", en II Jornades de Cultura Popular a les Pitiüses. Es vestir antic: 79-136. Eivissa: Federació de colles de ball i cultura popular d'Eivissa i Formentera. Ministerio DE Cultura. 1991. Moda en Sombras. Madrid: Ministerio de Cultura.

MONTAÑÉs, L. y J. BARRERA. 1987. Joyas. Madrid: Ed. Antiqvaria.

MuleT, A. 1951. "El traje balear en doce láminas del siglo XVIII", en Panorama Balear. Monografías de arte, vida, literatura y paisaje (dirección L. Ripio). Palma de Mallorca.

- 1954. El traje en Mallorca. Palma de Mallorca.

Mulet RAmis, B. 1979. Els teixits a Mallorca. Opuscle editat amb motiu de la "Mostra de Teixits Mallorquins" celebrada al Casal de la Ciutat de Mallorca. Ciutat de Mallorca.

- 1993. "Vestimenta dels mallorquins en el segle XVIII", en I Jornades de Cultura Popular a les Balears. Palma: Ayuntament de Muro-VIB.

Murillo Tuduri, A. y L. Plantalamor Massanet. 1979. "Descripción del traje típico menorquín de fines del siglo XVIII, según manuscrito de D. Juan Ramis y Ramis", en III Congreso Nacional de Artes y Tradiciones Populares: 499-508. Zaragoza: Instituto Fernando El Católico.

ORTEGa y Gasset, J. 1971. "Prólogo", a J. Ortiz Echagüe, España. Tipos y trajes.

Ortiz EChagüe, J. 1971. España. Tipos y trajes. San Sebastián. 12." ed.

PÉrez Cabrero, A. 1909. Ibiza, Arte: Arqueología. Barcelona: Imprenta de Joaquín Horta. PÉrez SÁnCheZ, A. 1986. Historia del dibujo en España. Madrid.

PIFERRER, P. y J. M. QUADRADO. 1888. Islas Baleares en España sus monumentos y artes, su naturaleza e bistoria. Barcelona: Ed. De Daniel Cortezo y C. ${ }^{a}$ 
PIGAL, E. 1825. Collection de Costumes des diverses Provinces De L'Espagne. Litographiés d'aprés des Dessins originaux Par Pigal, Litografía de Langlumé. París: Clement Fres Mds. D'Estampes.

PUIGGARí, J. 1890. Estudios de la indumentaria española concreta y comparada: cuadro bistórico. Siglos XIII y XIV. Barcelona: Imp. de Jaime Jesús y Roviralta.

- 1979. Monografia histórica e iconografía del traje. Barcelona.

Ribelles Y Helip, F. 1832. Colección de trajes de España. Madrid.

RODRíguez, A. (dib.) y A. AlBuERne (grab.). 1801. Colección General de los trajes que en la actualidad se usan en España, Principiada en el año 1801, en Madrid. Se hallará en la Librería del Castillo, frente a las gradas de San Felipe y de la Viuda del Cerro.

VARgas PONCE, J.. 1787. Descripción de las islas Pithiusas y Baleares. Madrid: Imprenta de la Viuda de Ibarra Hijos y Cía.

Vuillier, G. 1893. Les iles oubliées. París: Hachete. 